

\section{BUKU AJAR \\ PERANCANGAN BERBASIS KOMPUTER DENGAN INTEGRASI ARDUINO DAN ANDROID}

\section{Penulis}

Eko Agus Suprayitno, S.Si, MT

Rohman Dijaya, S.Kom, M.Kom

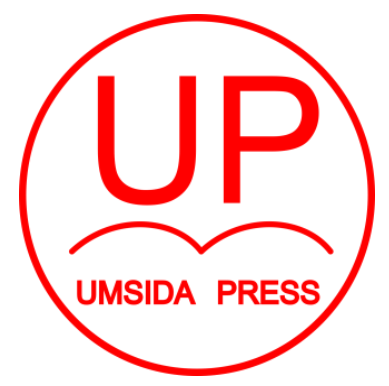

Diterbitkan oleh UMSIDA PRESS

J1. Mojopahit 666 B Sidoarjo ISBN: 978-602-5914-05-8

Copyright@2018. Authors

All rights reserved 


\section{BUKU AJAR \\ PERANCANGAN BERBASIS KOMPUTER DENGAN INTEGRASI ARDUINO DAN ANDROID}

\section{Penulis :}

Eko Agus Suprayitno, S.Si, MT

Rohman Dijaya, S.Kom, M.Kom

\section{ISBN :}

978-602-5914-05-8

\section{Editor :}

Septi Budi Sartika, M.Pd

M. Tanzil Multazam, S.H., M.Kn.

\section{Copy Editor :}

Fika Megawati, S.Pd., M.Pd.

Design Sampul dan Tata Letak :

Mochamad Nashrullah, S.Pd

\section{Penerbit :}

UMSIDA Press

\section{Redaksi :}

Universitas Muhammadiyah Sidoarjo

J1. Mojopahit No 666B

Sidoarjo, Jawa Timur

Cetakan pertama, 
(C) Hak cipta dilindungi undang-undang Dilarang memperbanyak karya tulis ini dengan suatu apapun tanpa ijin tertulis dari penerbit.

\section{IDENTITAS BUKU}

1. Judul Buku : PERANCANGAN BERBASIS KOMPUTER DENGAN INTEGRASI ARDUINO DAN ANDROID

2. Penulis : Eko Agus Suprayitno, S,Si, MT

\& Rohman Dijaya.Skom., M.Kom

3. Penerbit : UMSIDA PRESS

4. Cetakan : Pertama, Sidoarjo

5. Jumlah Halaman : 103 Halaman

6. Tahun $: 2018$

Belakangan ini mikrokontroler keluarga Arduino Uno menjadi sangat popular. Tidak mengherankan jika turunan mikrokontroler tersebut pun bermunculan. Kepopulerannya tidak luput dari dukungan berbagai vendor yang menyediakan berbagai komponen yang dapat mendukung Arduino Uno dalam pengaplikasiannya. Disamping itu perkembangan teknologi jika tidak terintegrasi dengan smartphone juga akan kurang lengkap. Android sudah menempati posisi utama di setiap smartphone yang ada di Indonesia. Belajar mengintegrasikan Smartphone android dengan Arduino salah 
sau peluang besar dalam meningkatkan daya saing teknologi di rana elektronika. Modul ini mencoba untuk membantu siapa saja yang mempelajari Panduan Praktik Mempelajari Mikrokontroler Menggunakan Arduino Uno dan integrasinya dengan Aplikasi di Smartphone Android. Arduino uno sendiri merupakan salah satu mata kuliah dalam bidang Teknik Elektro, Ilmu Komputer, dan Teknik Informatika yang sangat penting untuk dikuasai oleh mahasiswa sejak tingkat menengah. Modul ini disusun untuk membantu mahasiswa dalam memahami konsep elektronika dan sensor dengan cepat dan mudah, serta memudahkan mahasiswa mengontrol Hardware dengan bantuan smartphone. Pada buku ini, penulis menyusun modul dengan jumlah 10 bab, yakni Mengendalikan LCD sebagai Display pada Arduino, Rangkaian Motor DC, Rangkaian Sensor Ultrasonik, Rangkaian I2C LCD 16x2, Rangakaian Sensor LM 35, Rangkaian Relay, Sensor MAX30100, Sensor Suhu DS18B20, Komunikasi Arduino dengan Android memanfaatka Bluetooth, Filter pada Instrumentasi Biomedik. 


\section{KATA PENGANTAR}

Segala puji dan syukur penulis panjatkan ke hadirat Tuhan Yang Maha Esa, yang telah memberikan berkat dan karuniannya sehingga penulis dapat menyelesaikan PERANCANGAN BERBASIS KOMPUTER DENGAN INTEGRASI ARDUINO DAN ANDROID ini dengan baik. Perkembangan ilmu pengetahuan dan teknologi saat ini sangatlah cepat. Terutama Kemajuan teknologi dibidang Teknologi Informasi dan Komunikasi Otomasi. Perkembangan dan Kemajuan Teknologi tersebut tidak lepas dari semangat untuk memudahkan kehidupan dan komunikasi manusia. Sehingga integrasi keilmuan secara ilmiah antara pengembang teknologi lintas bidang keahlian sangat diperlukan.

Belakangan ini mikrokontroler keluarga Arduino Uno menjadi sangat popular. Tidak mengherankan jika turunan mikrokontroler tersebut pun bermunculan. Kepopulerannya tidak luput dari dukungan berbagai vendor yang menyediakan berbagai komponen yang dapat mendukung Arduino Uno dalam pengaplikasiannya. Disamping itu perkembangan teknologi jika tidak terintegrasi dengan smartphone juga akan kurang lengkap. Android sudah menempati posisi utama di setiap smartphone yang ada di Indonesia. Belajar mengintegrasikan Smartphone android dengan Arduino salah satu peluang besar dalam meningkatkan daya saing teknologi di rana elektronika. Modul ini mencoba untuk membantu siapa saja yang mempelajari Panduan Praktik Mempelajari Mikrokontroler Menggunakan Arduino Uno dan integrasinya dengan Aplikasi di Smartphone Android. Arduino uno sendiri 
merupakan salah satu mata kuliah dalam bidang Teknik Elektro, IImu Komputer, dan Teknik Informatika yang sangat penting untuk dikuasai oleh mahasiswa sejak tingkat menengah. Modul ini disusun untuk membantu mahasiswa dalam memahami konsep elektronika dan sensor dengan cepat dan mudah, serta memudahkan mahasiswa mengontrol Hardware dengan bantuan smartphone. Pada buku ini, penulis menyusun modul dengan jumlah 10 bab, yakni mengendalikan LCD 16X2, Mengendalikan Motor DC, Membaca sensor Ultrasonik, Membaca sensor LM35, mengedalikan Relay, Menggabungkan 12C dengan LCD16x2, Membuat Aplikasi Android dengan MIT App Inventor, Integrasi Bluetooth HC 05 Arduino dengan Aplikasi Android, Menampilkan Nilai sensor Suhu dan jarak Arduino pada Aplikasi Android, Modul Wifi ESP8266-01 dan Nodemcu.

\begin{abstract}
Dengan dibuatnya Buku Instrumentasi PERANCANGAN BERBASIS KOMPUTER DENGAN INTEGRASI ARDUINO DAN ANDROID ini, penulis berharap banyak masyarakat, Mahasiswa, enginer, maupun pendidik mampu memahami, mampu membuat dan mengembangkannya menjadi Instrumentasi yang tepat guna dan akurat.
\end{abstract}

Sidoarjo, 20 Januari 2018

Penulis 


\section{DAFTAR ISI}

1. Mengendalikan LCD sebagai Display pada Arduino
a. Tujuan
b. Teori LCD $16 \times 2$ dan Pemrograman Arduino
c. Tugas Keterampilan Pemahaman \& Pemrograman

2. Rangkaian Motor DC
a. Tujuan
b. Teori Motor DC dan Pemrograman Arduino
c. Tugas Keterampilan Pemahaman \& Pemrograman

3. Rangkaian sensor Ultrasonik
a. Tujuan
b. Teori Sensor Ultrasonik dan Pemrograman Arduino
c. Tugas Keterampilan Pemahaman \& Pemrograman

4. Rangkaian I2C LCD 16×2

a. Tujuan

b. Teori 12C LCD 16x2 dan Pemrograman Arduino

c. Tugas Keterampilan Pemahaman \& Pemrograman

5. Rangakaian Sensor LM 35

a. Tujuan

b. Teori Sensor Sensor LM 35 dan Pemrograman Arduino

c. Tugas Keterampilan Pemahaman \& Pemrograman

6. Rangkaian Relay

a. Tujuan

b. Teori Relay dan Pemrograman Arduino

c. Tugas Keterampilan Pemahaman \& Pemrograman

7. Sensor MAX30100

a. Tujuan 
b. Teori Sensor MAX30100 dan Pemrograman Arduino

c. Tugas Keterampilan Pemahaman \& Pemrograman

8. Sensor Suhu DS18B20

a. Tujuan

b. Teori Sensor Suhu DS18B20 dan Pemrograman Arduino

c. Tugas Keterampilan Pemahaman \& Pemrograman

9. Komunikasi Arduino dengan Android memanfaatka Bluetooth

a. Tujuan

b. Teori Bluetooth, Sofware Android MIT Inventor dan Pemrograman Arduino Sofware Android MIT Inventor

c. Tugas Keterampilan Pemahaman \& Pemrograman

10. Filter pada Instrumentasi Biomedik

a. Instrumentasi Low Pass Filter

b. Instrumentasi High Pass Filter

c. Instrumentasi Notch Filter 


\section{BAB}

11. BAB I : Mengendalikan LCD sebagai Display pada Arduino

12. BAB II : Rangkaian Motor DC

13. Bab III : Rangkaian Sensor Ultrasonik

14. Bab IV : Rangkaian I2C LCD 16×2

15. Bab V : Rangakaian Sensor LM 35

16. Bab VI : Rangkaian Relay

17. BAB VII : Sensor MAX30100

18. BAB VIII: Sensor Suhu DS18B20

19. BAB IX :Komunikasi Arduino dengan Android memanfaatka Bluetooth

20. BAB X : Filter pada Instrumentasi Biomedik 


\section{CAPAIAN PEMBELAJARAN}

1. Mahasiswa dapat Mengetahui dan memahami prinsip kerja Sensor Tepat Guna di bidang Elektronika dan Otomasi secara Umum

2. Mahasiswa Mampu melakukan pemrogram otomasi sensor dan integrasinya dengan sensor-sennsor lainnya untuk aplikasinya pada teknologi Tepat Guna

3. Mahasiswa dapat mampu membuat Aplikasi Android pada Smartphone

4. Mahasiswa Mampu memahami komunikasi Nirkabel antara Arduino dengan Aplikasi Android di Smartphone

5. Mahasiswa mampu membuat Teknologi Tepat Guna Otomatis yang bermanfaat bagi masyarakat dengan memanfaatkan sensor yang ada

6. Mahasiswa mampu mengendalikan Hardware Teknologi Tepat Guna menggunakan Aplikasi Android di Smartphone.

7. Mahasiswa mampu Filter-filter Instrumentasi Medis yang terintegrasi dengan mikrokontroller 
BAB I

Mengendalikan LCD sebagai Display pada Arduino

\section{Instrumentasi LCD (Liquid Crystal Display) 16x2}

\section{A. TUJUAN}

Mengenal Komponen LCD (Liquid Crystal Display), Membuat Tulisan di LCD, dan Memprogram Karakter Tulisan di LCD $16 \times 2$.

B. TEORI

LCD (Liquid Crystal Display) merupakan suatu display tampilan karakter yang dibuat dari bahan cairan Kristal yang pengoperasiannya menggunakan system dot matriks. LCD (Liquid Crystal Display) 16×2 dapat menampilkan sebanyak 32 karakter yang terdiri dari 2 baris dan tiap baris dapat menampilkan 16 karakter. (Andrianto H, Darmawan A. 2016).

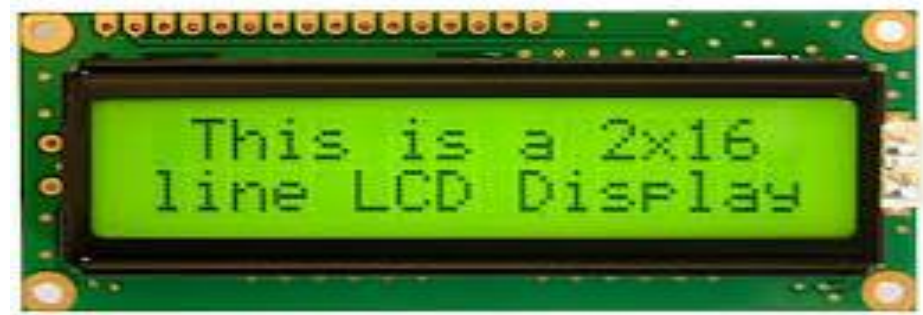

Gambar 1 LCD16x2 (Andrianto H, Darmawan A. 2016). Tabel 1: Fungsi Pin LCD Character 16x2 (Wardhana, Lingga 2006). 


\begin{tabular}{|c|c|c|}
\hline PIN & Name & Function \\
\hline 1 & Vss & Ground voltage \\
\hline 2 & $V_{c c}$ & $+5 \mathrm{~V}$ \\
\hline 3 & $V_{E B}$ & Contrast voltage \\
\hline 4 & RS & $\begin{array}{l}\text { Register Select } \\
0=\text { Instruction Register } \\
1=\text { Data Register }\end{array}$ \\
\hline 5 & $\mathrm{RW}$ & $\begin{array}{l}\text { Read } / \text { Write, to choose write or read mode } \\
0=\text { write mode } \\
1=\text { read mode }\end{array}$ \\
\hline 6 & E & $\begin{array}{l}\text { Enable } \\
0=\text { start to lacht data to LCD character } \\
1=\text { disable }\end{array}$ \\
\hline 7 & $\mathrm{DB} 0$ & LSB \\
\hline 8 & $\mathrm{DB} 1$ & - \\
\hline 9 & $\mathrm{DB} 2$ & - \\
\hline 10 & DB3 & - \\
\hline 11 & DB4 & - \\
\hline 12 & DB5 & - \\
\hline 13 & DB6 & - \\
\hline 14 & DB7 & MSB \\
\hline 15 & BPL & Back Plane Light \\
\hline 16 & GND & Ground voltage \\
\hline
\end{tabular}

Pada LCD yang berukuran 16×2 (16 kolom, 2 baris) terdapat 32 koordinat yang berarti dapat ditempati 32 karakter. Maksud dari ukuran 16x2 (16 kolom, 2 baris) yakni bertujuan untuk memudahkan dalam meletakkan kursor di kolom 0-15 (kolom pertama) pada baris ke 0 maupun baris ke 1. Untuk baris utama pada LCD disebut baris ke 0 yang biasanya ada di baris atas sendiri, dan baris ke 1 biasanya posisinya setelah baris ke 0 . Untuk memudahkan Ilustrasinya maka lihat gambar system koordinat yang berlaku di LCD terkait penempatan kolom dan baris sebagai berikut : 


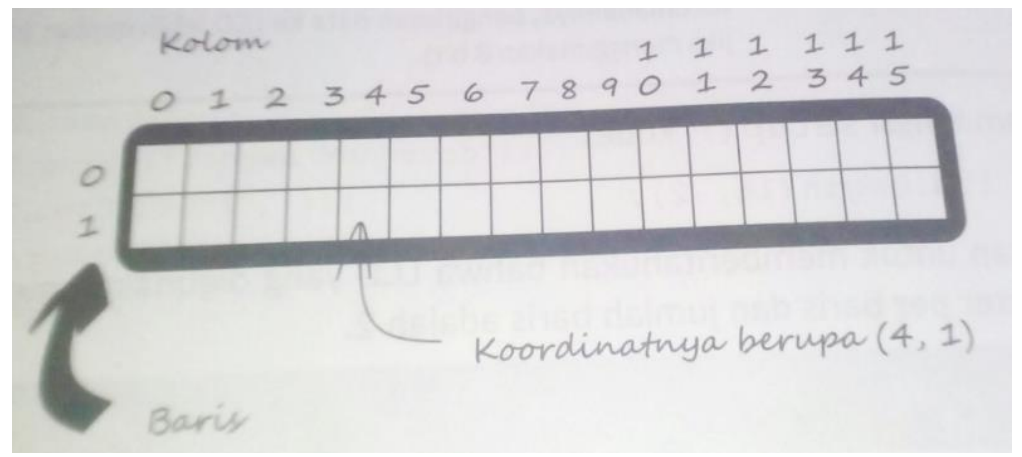

Gambar 2: system koordinat di LCD (Kadir A, 2013)

Koordinat pojok kiri-atas dinyatakan $(0,0)$, sedangkan koordinat pojok kanan-atas berupa $(0,15)$, Jadi secara umum, koordinat dinyatakan dengan (kolom, Baris).

> Sebagai contoh Koordinat dari kolom 0-15, baris 0 yang mengikuti acuan (kolom, Baris) seperti berikut ini :

Koordinat $(0,0)$, koordinat $(1,0)$, koordinat $(2,0)$, korrdinat $(3,0)$, koordinat $(4,0)$, koordinat $(5,0)$, koordinat $(6,0)$, koordinat $(7,0)$, koordinat $(8,0)$, koordinat $(9,0)$, koordinat $(10,0)$, koordinat $(11,0)$, koordinat $(12,0)$, koordinat $(13,0)$, koordinat $(14,0)$, koordinat $(15,0)$.

$>$ Sebagai contoh koordinat kolom 0-15, baris 1 yang mengikuti acuan (kolom, Baris) seperti berikut ini : Koordinat $(0,0)$, koordinat $(1,1)$, koordinat $(2,1)$, korrdinat $(3,1)$, koordinat $(4,1)$, koordinat $(5,1)$, koordinat $(6,1)$, koordinat $(7,1)$, koordinat $(8,1)$, koordinat $(9,1)$, koordinat $(10,1)$, koordinat $(11,1)$, koordinat $(12,1)$, koordinat $(13,1)$, koordinat $(14,1)$, koordinat $(15,1)$. (Kadir A, 2013). 
Material yang digunakan dalam Latihan pengoprasian LCD (Liquid Crystal Display) 16×2 dengan Arduino dapat dilakukan dengan cara berikut.

\section{LCD1}

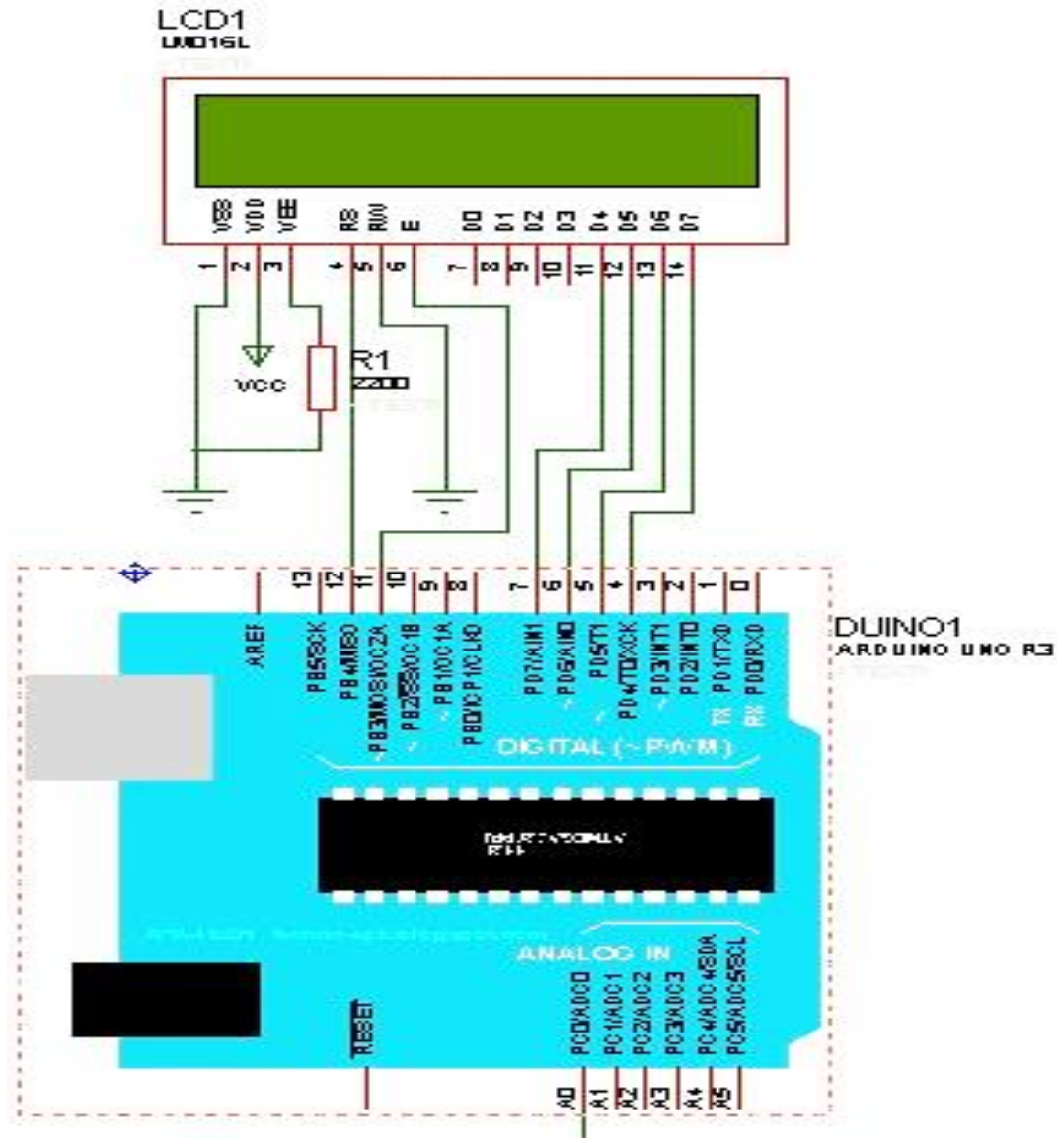

Gambar 3. Skematik Rangkain LCD (Liquid Crystal Display) $16 \times 2$

\section{Persiapan secara Mekanik pada Hardware}


1. Perhatikan Gambar 3 Skematik Rangkain $L C D$ diatas sebagai ilustrasi dalam uji cobanya. Berikutnya ikuti langkah seperti panduan point nomor 2 hingga point nomor 11. Untuk memudahkan dalam praktek maka siapkan Modul Hardware Arduino UNO, Kabel USB Arduino ke PC, Kabel Jumper, LCD, dan Install Software Arduino IDE pada PC anda.

2. Masukkan kabel jumper ke pin digital Arduino no.4 kemudian sambungkan kabel jamper tersebut ke kaki LCD No.14/D7.

3. Masukkan kabel jumper ke pin digital Arduino no.5 kemudian sambungkan kabel jamper tersebut ke kaki LCD No.13/D6.

4. Masukkan kabel jumper ke pin digital Arduino no.6 kemudian sambungkan kabel jamper tersebut ke kaki LCD No.12/D5.

5. Masukkan kabel jumper ke pin digital Arduino no.7 kemudian sambungkan kabel jamper tersebut ke kaki LCD No.11/D4.

6. Masukkan kabel jumper ke pin digital Arduino no.11 kemudian sambungkan kabel jamper tersebut ke kaki LCD No.6/E.

7. Masukkan kabel jumper ke LCD No.5/ R/W lalu untuk output LCD No.5/ R/W pasanglah ke Ground.

8. Masukkan kabel jumper ke pin digital Arduino no.12 kemudian sambungkan kabel jamper tersebut ke kaki LCD No.4/RS.

9. Masukkan kabel jumper ke LCD No.3/VEE lalu untuk output dari LCD No.3/VEE pasanglah ke Input Resistor dengan 
ukuran Hambatannya 2200 ohm. Setelah kabel terpasang ke Resistor untuk outputnya pasang menuju ke Ground.

10. Masukkan kabel jumper ke LCD No.2/VCC lalu output dari LCD No.2/VCC pasang menuju VCC.

11. Masukkan kabel jumper ke LCD No.1/VSS lalu output dari LCD No.1/VSS pasang ke Ground.

\section{Persiapan secara Software Arduino IDE:}

1. Nyalakan komputer dan Buka Program Arduino IDE

2. Ketik Algoritma sebagaimana contoh pada Gambar 4 atau Algoritma Menampilkan karakter di LCD 16x2 .

3. Setelah memasukkan algoritma pada Arduino IDE maka Verifikasi Algoritma yang sudah anda buat agar bisa dideteksi kesalahan dalam penulisan programnya

4. Compail Algoritma pada modul Arduino agar bisa dilihat hasilnya pada LCD

5. Lihat hasilnya pada tampilan LCD.

6. Untuk memudahkan pemrograman lihat Algoritma pada Gambar 4. 
File Edit Sketch Tools Help

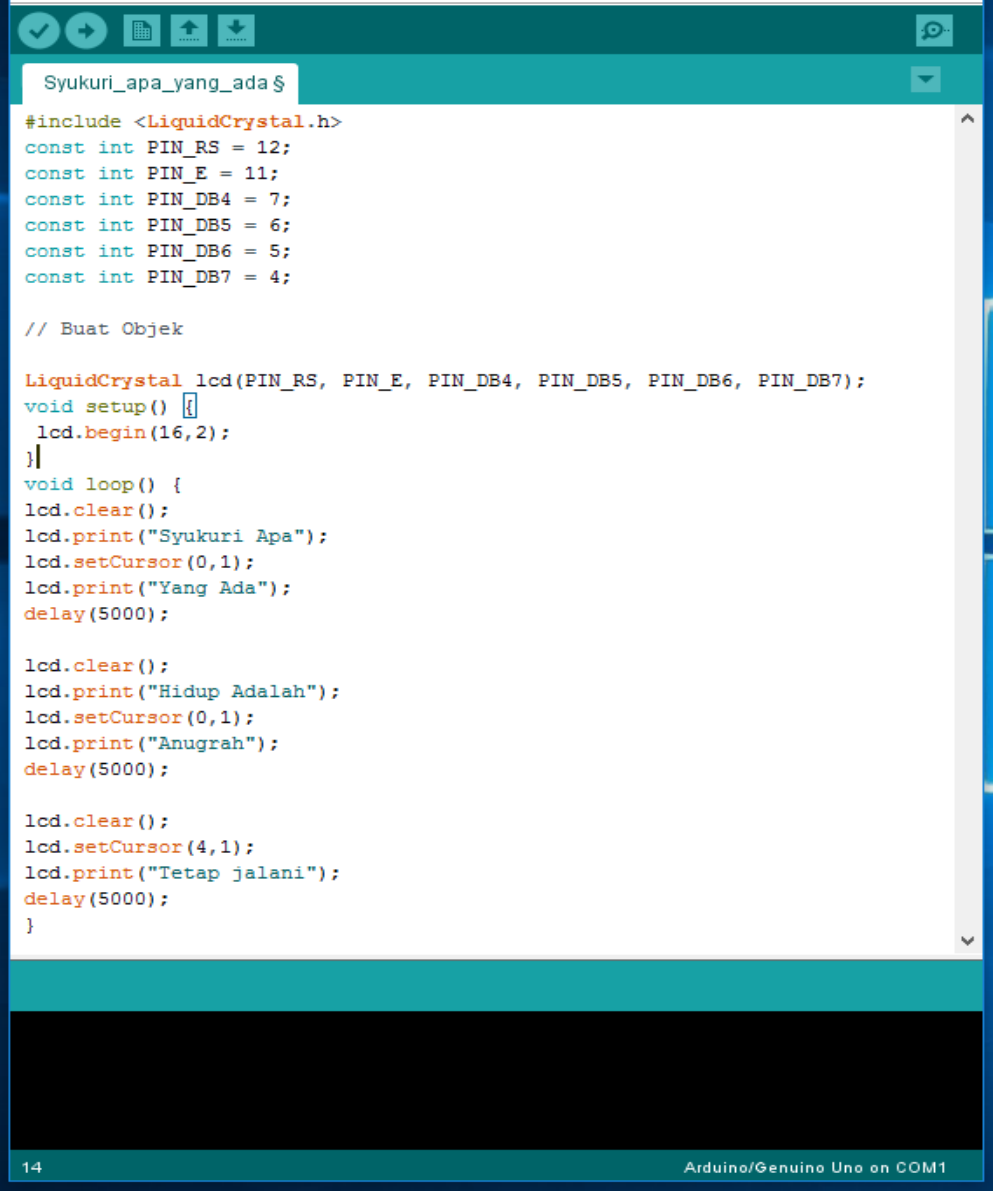

Gambar 4. Algoritma pada IDE Arduino 
Algoritma yang harus di tuliskan : 


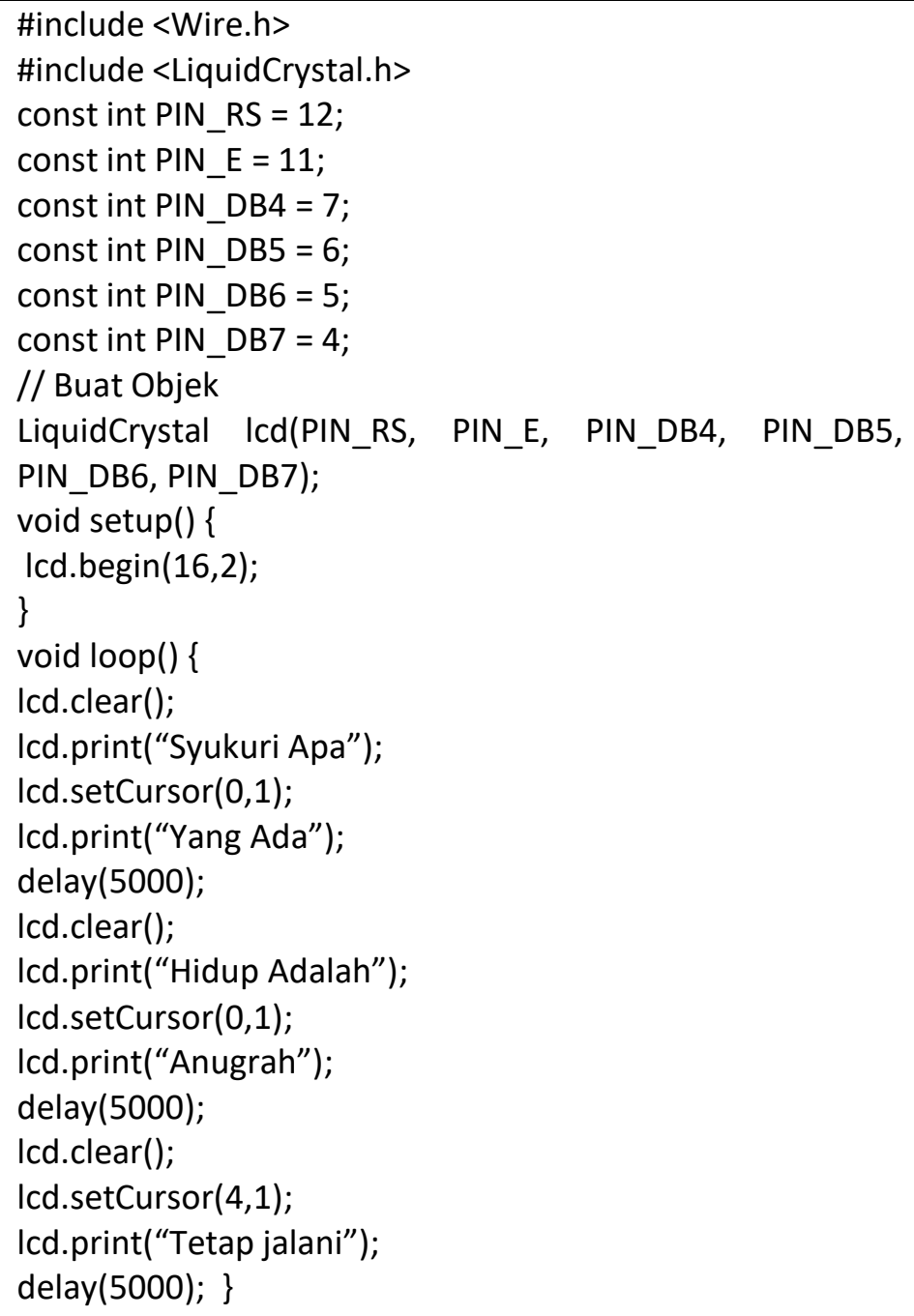


7. Tulis karakter berdasarkan koordinat (kolom, Baris) untuk keterangan seperti sebagaimana tabel berikut ini, dan Foto Hasilnya untuk dimasukkan pada Laporan Praktikum.

\begin{tabular}{|c|c|c|c|}
\hline No & $\begin{array}{c}\text { Koordinat } \\
\text { (Kolom, } \\
\text { Baris) }\end{array}$ & Karakter & Hasil Foto \\
\hline 1 & $(3,0)$ & Nama & \\
\hline 2 & $(2,1)$ & NIM & \\
\hline 3 & $(0,1)$ & Jurusan & \\
\hline 4 & $(4,0)$ & Institusi & \\
\hline 5 & $(5,1)$ & Hobi & \\
\hline
\end{tabular}

\section{TUGAS}

1. Jelaskan macam-macam tipe ukuran LCD selain LCD $16 \times 2$ dan tentukan macam-macam koordinatnya.

2. Jelaskan Fungsi void setup() dan void loop() pada Arduino IDE. 


\section{BAB 2}

\section{RANGKAIAN MOTOR DC}

\section{INSTRUMENTASI MOTOR DC}

\section{A. TUJUAN}

Mengenal Motor DC, Merakit agar Motor DC bisa berputar, dan Memprogram Arduino IDE untuk menggerakkan Motor DC.

\section{B. TEORI}

\section{Motor DC}

Motor DC ialah motor yang menggunakan sumber tegangan DC dan digunakan untuk mengubah tenaga listrik menjadi tenaga mekanis. Komponen ini bekerja dengan prinsip electromagnet. Apabila Motor DC diberi tegangan, maka medan magnet yang diam atau disebut stator akan terbentuk. Medan magnet ini membuat rotor atau bagian yang bergerak atau berputar akan dapat dimanfaatkan untuk memutar benda yang sulit untuk manusia kerjakan. Kecepatan Motor DC sendiri tergantung dengan besarnya tegangan. Semakin besar tegangan akan semakin cepat Motor DC berputar dan begitu juga sebaliknya apabila Motor DC mendapatkan tegangan kecil maka kecepatan juga akan lamban. Namun tegangan yang terdapat di Motor DC memiliki batasan dalam bekerja atau berputar. Apabila kemampuan Motor DC di hiraukan maka Motor akan terbakar. Contoh Gambar 1. adalah motor spesifikasi tegangan 1,5V-5V (Kadir A, 2013). Motor DC memiliki kutup positif dan kutub negatif, kutub-kutub tersebut mempengaruhi jenis arah putaran Motor DC. 


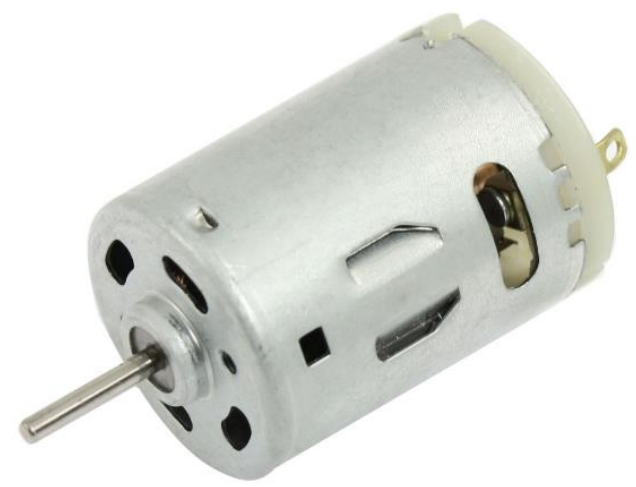

Gambar 1. Bentuk Motor DC (Kadir A 2013)

\section{Relay}

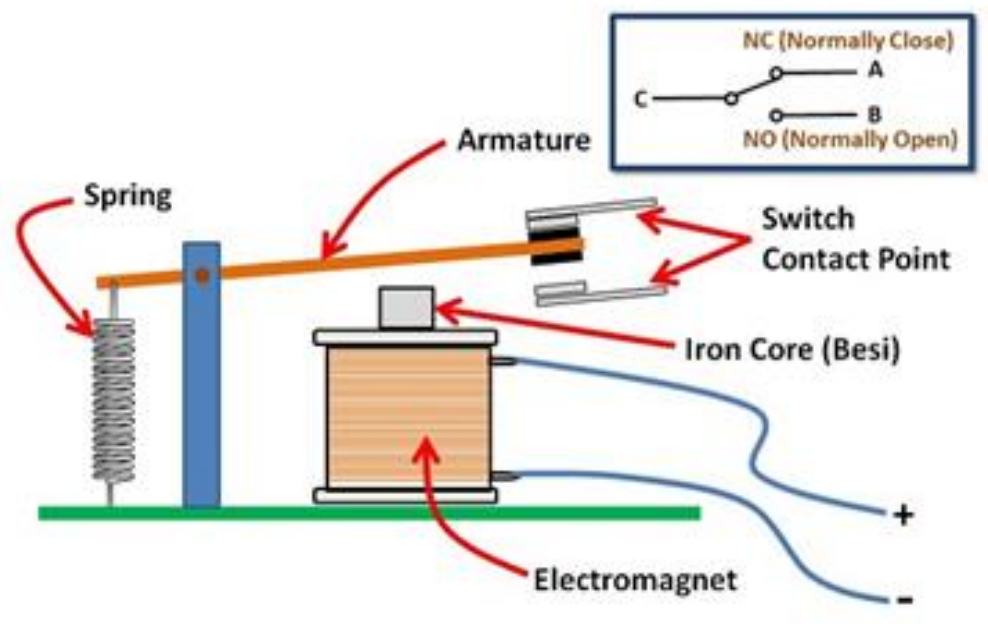

Gambar 2. Struktur sederhana Relay

Relay merupakan suatu Saklar (Switch) elektromagnetik yang apabila kumparan pada relay di aliri arus listrik dapat membuat Inti Besi (Iron Core) menjadi magnet sehingga dapat menarik kontak (Armatur) jika gaya 
magnet yang dihasilkan menjadi lebih besar dari pada gaya pegas (spring) yang ada sebagaimana ilustrasi pada gambar (aziz, 2009). Relay yang menggunakan Elektromagnet 5V dan $50 \mathrm{~mA}$ mampu menggerakan Armature Relay (yang berfungsi sebagai saklarnya) untuk menghantarkan listrik 220V 2 A.

Berdasarkan pada Gambar diatas Kontak Poin Relay terdiri dari 2 jenis yaitu :

- Normally Close (NC) yaitu kondisi awal sebelum diaktifkan akan selalu berada di posisi CLOSE (tertutup)

- Normally Open (NO) yaitu kondisi awal sebelum diaktifkan akan selalu berada di posisi OPEN (terbuka)

Pada gambar diatas apabila Kumparan Coil dilewati arus listrik, maka akan timbul gaya Elektromagnet yang akan menarik Armature untuk berpindah dari Posisi sebelumnya (NC) ke posisi baru (NO), sehingga Saklar dapat menghantarkan arus listrik di posisi (NO). Sehingga Posisi awal Armature sebelumnya (NC) menjadi tidak terhubung. Begitu sebaliknya ketika Kumparan Coil tidak dialiri arus listrik maka Armature akan kembali lagi ke posisi Normally Close (NC). Arus listrik yang dibutuhkan dalam memindahkan kontak dari NC ke NO relatif kecil. Perlu diketahui bahwa Relay ada yang aktif Low dan aktif High. Maksudnya aktif Low adalah relay akan aktif jika diberi masukan LOW atau nol, sedangkan aktif High adalah relay akan aktif jika diberi masukan HIGH atau satu.

Berikut ini Contoh gambar pemasangan Relay 2 Chanel pada Arduino UNO untuk menyalakan dan mematikan Lampu. 


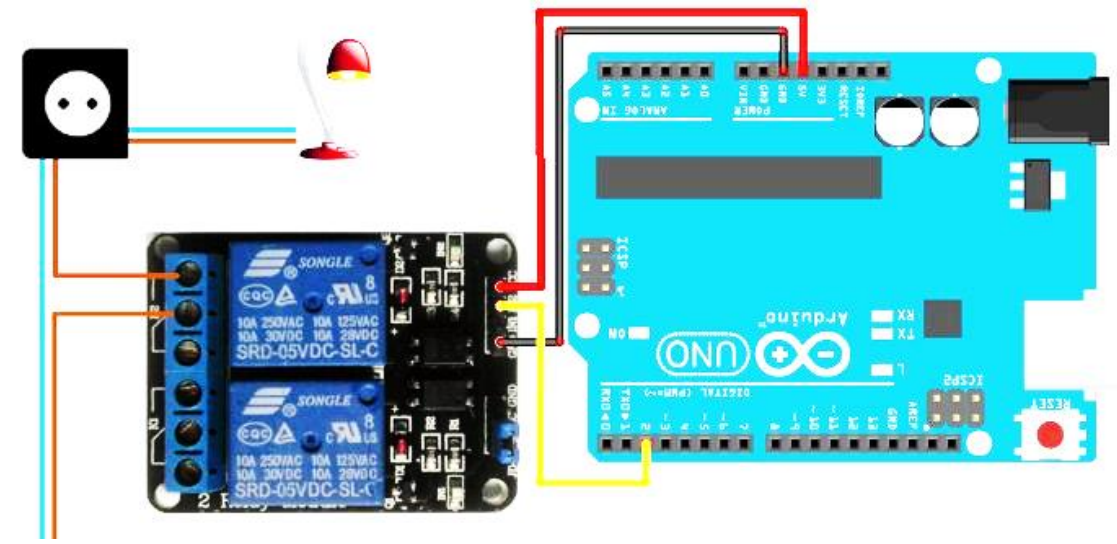

Gambar 3. Pemasangan Relay 2 Chanel pada Arduino UNO

Material yang digunakan dalam latihan penggunaan motor $D C$ dapat dilakukan dengan cara berikut. 


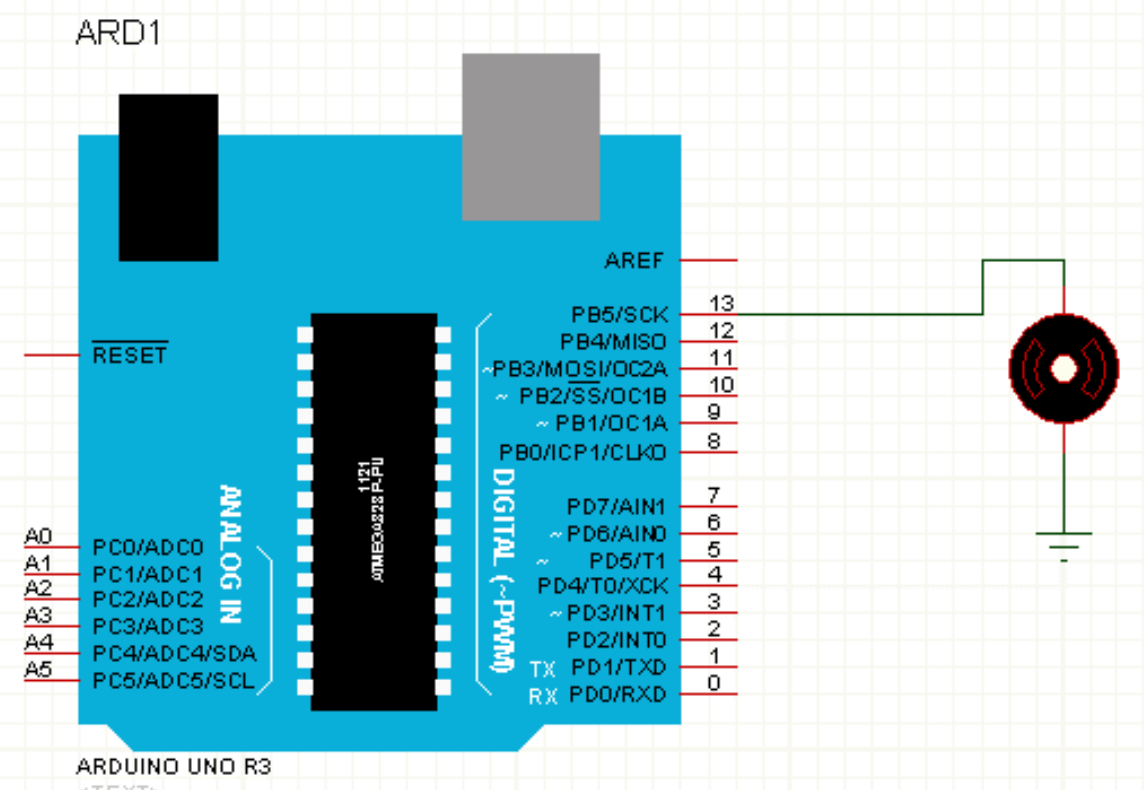

Gambar 4. Rangkaian Motor DC

1. Siapkan Arduino Uno sebelum merakit Motor DC.

2. Gunakan Motor DC sesuai dengan tegangan yang sudah ditentukan.

3. Motor DC pada praktikum ini akan digerakkan dengan bantuan Supplay Tegangan 12 Volt sehingga butuh relay dalam pengoprasiannya. Relay yang digunakan pada praktikum ini adalah tipe relay Aktif LOW. Sehingga Masukkan kabel jumper warna merah pada Normally Close (NC) dan Normally Open (NO) supplay tegangan 12 Volt untuk menggerakkan Motor seperti gambar dibawah ini. Taruh kabel hitam Motor DC pada ground. 


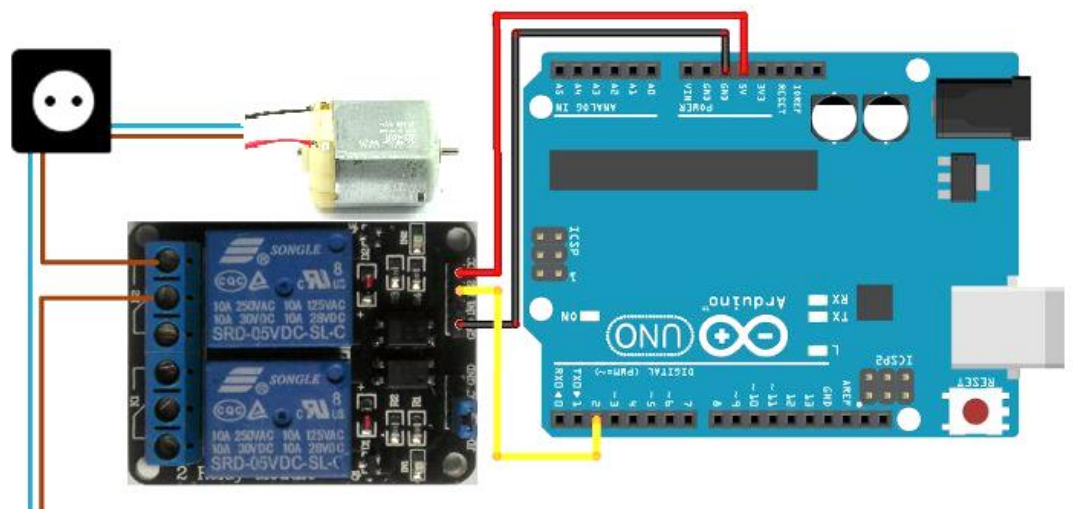

Gambar 5. pemasangan Relay 2 Chanel pada Arduino UNO

4. Masukkan kabel jumper pada Pin 12 Arduino (digital) dan hubungkan pin tersebut ke pin masukan (Input) Relay 4 Chanel. Masukkan Ground Relay 4 Chanel ke ground Arduino Uno. Serta Masukkan supplay (vcc) Relay 4 Chanel ke vcc Arduino Uno.

5. Program Arduino IDE seperti coding dibawah ini :

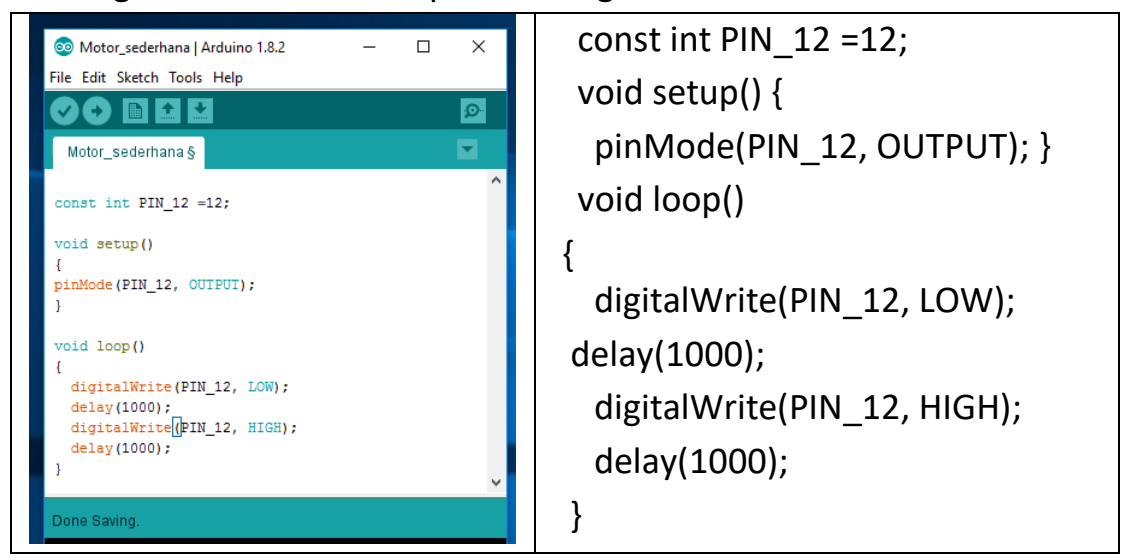


6. Setelah memasukkan algoritma pada Arduino IDE maka Verifikasi Algoritma yang sudah anda buat agar bisa dideteksi kesalahan dalam penulisan programnya

7. Compail Algoritma pada modul Arduino agar bisa dilihat hasilnya pada Lputaran motor

8. Isi tabel berikut ini untuk menggerakkan Motor jika ketentuannya sebagai berikut :

\begin{tabular}{|l|l|l|l|l|}
\hline No & $\begin{array}{l}\text { Posisi PIN } \\
\text { Arduino }\end{array}$ & Delay & $\begin{array}{c}\text { Kecepatan } \\
\text { Putaran } \\
\text { Motor (rpm) }\end{array}$ & $\begin{array}{l}\text { Foto } \\
\text { Hasil }\end{array}$ \\
\hline 1 & Pin 13 & 2000 & & \\
\hline 2 & Pin 9 & 1000 & & \\
\hline 3 & Pin 6 & 1500 & & \\
\hline 4 & Pin 2 & 2500 & & \\
\hline 5 & Pin 4 & 1000 & & \\
\hline
\end{tabular}

\section{TUGAS}

1. Apakah Motor DC dapat Berputar dengan baik jika kabel jamper antara relay dengan arduino dimasukkan di Pin Analog Arduino (AO) ?

2. Apa alat ukur yang digunakan untuk mengukur putaran Motor ? dan apa satuannya ? 


\section{BAB III \\ RANGKAIAN SENSOR ULTRASONIK}

\section{INSTRUMENTASI SENSOR ULTRASONIK}

\section{A. TUJUAN}

Mengoprasikan, memanfaatkan, dan memprogram Sensor HC-SRO4 (Ultrasonik) untuk mengukur jarak atau kedalaman.

\section{B. TEORI}

Sensor ultrasonik bekerja dengan cara memancarkan suatu gelombang dan kemudian menghitung waktu pantulan gelombang tersebut. Gelombang ultrasonik bekerja pada frekuensi mulai dari $20 \mathrm{KHz}$ sampai dengan 20 $\mathrm{MHz}$. frekuensi kerja yang digunakan dalam gelombang ultrasonik bervariasi tergantung pada medium yang dilalui, mulai dari kerapatan pada fasa gas, cair, hingga padat. Sensor ultrasonik terdiri dari sebuah chip pembangkit sinyal $40 \mathrm{KHz}$, sebuah speaker ultrasonik, dan sebuah microphone ultrasonik. Speaker ultrasonik (transmitter) mengubah sinyal $40 \mathrm{KHz}$ menjadi suara sementara microphone ultrasonik (receiver) berfungsi untuk mendeteksi pantulan suaranya. Sensor ultrasonik akan mengirimkan suara ultrasonik ketika ada pulsa trigger dari mikrokontroler. Suara ultrasonik dengan frekuensi sebesar $40 \mathrm{KHz}$ akan dipancarkan selama $200 \mathrm{uS}$. Suara ini akan merambat di udara dengan kecepatan 340 m/s atau 29.412 uS setiap $1 \mathrm{~cm}$, mengenai objek dan akan terpantul kembali ke sensor ultrasonik. Selama menunggu pantulan, sensor ultrasonik akan menghasilkan sebuah pulsa. Pulsa ini akan berlogika low ketika suara pantulan terdeteksi oleh sensor ultrasonik. Maka dari itu, lebar pulsa dapat 
merepresentasikan jarak antara sensor ultrasonik dengan objek. Contoh Gambar sensor ultrasonic dapat dilihat seperti gambar berikut ini. (Andirianto $H$, Darmawan $A$ 2016)

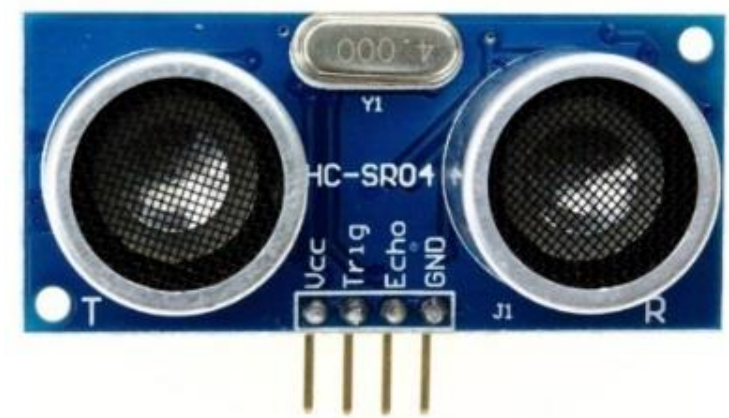

Gambar 1. Sensor Ultrasinik. (Andirianto H, Darmawan A 2016)

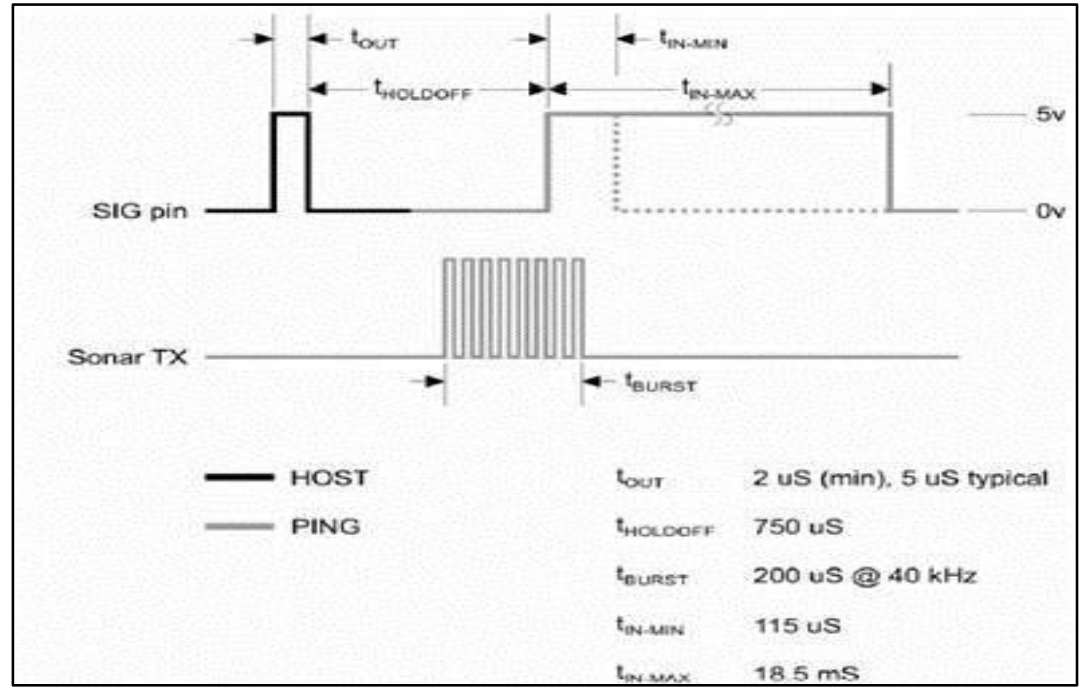

Gambar 2. Diagram waktu sensor ultrasonik (Andirianto H, Darmawan A 2016) 
Sensor Ultrasonik memiliki 4 pin yang diantaranya pin Grounf, pin vcc, pin Transmitter dan Receiver. Pin Transmitter dan Receiver akan terhubung ke pin Digital Arduino.

Material yang digunakan dalam latihan penggunaan sensor ultrasonik dapat dilakukan dengan cara berikut.

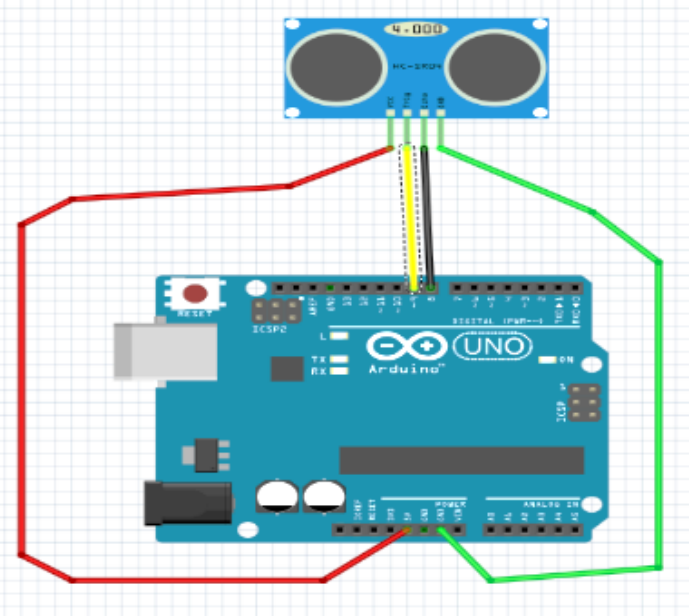

Gambar 3. Rangkaian Sensor Ultrasonik

1. Siapkan dulu Aruduino Uno sebelum kita merakit Sensor Ultrasonik sebagaimana gambar 3 diatas dengan rincian komponennya adalah sebagai berikut : Arduino UNO, Kabel jumper, sensor ultrasonic, dan Penggaris

2. Siapkan Sensor Ultrasonik.

3. Pasang LCD $16 \times 2$ Seperti Percobaan Modul 1 awal Praktikum ini, dengan memperhatikan pin-pin antara Arduino dengan LCD $16 \times 2$. LCD disini digunakan untuk menampilkan jarak yang terbaca oleh sensor Ultrasonik. 


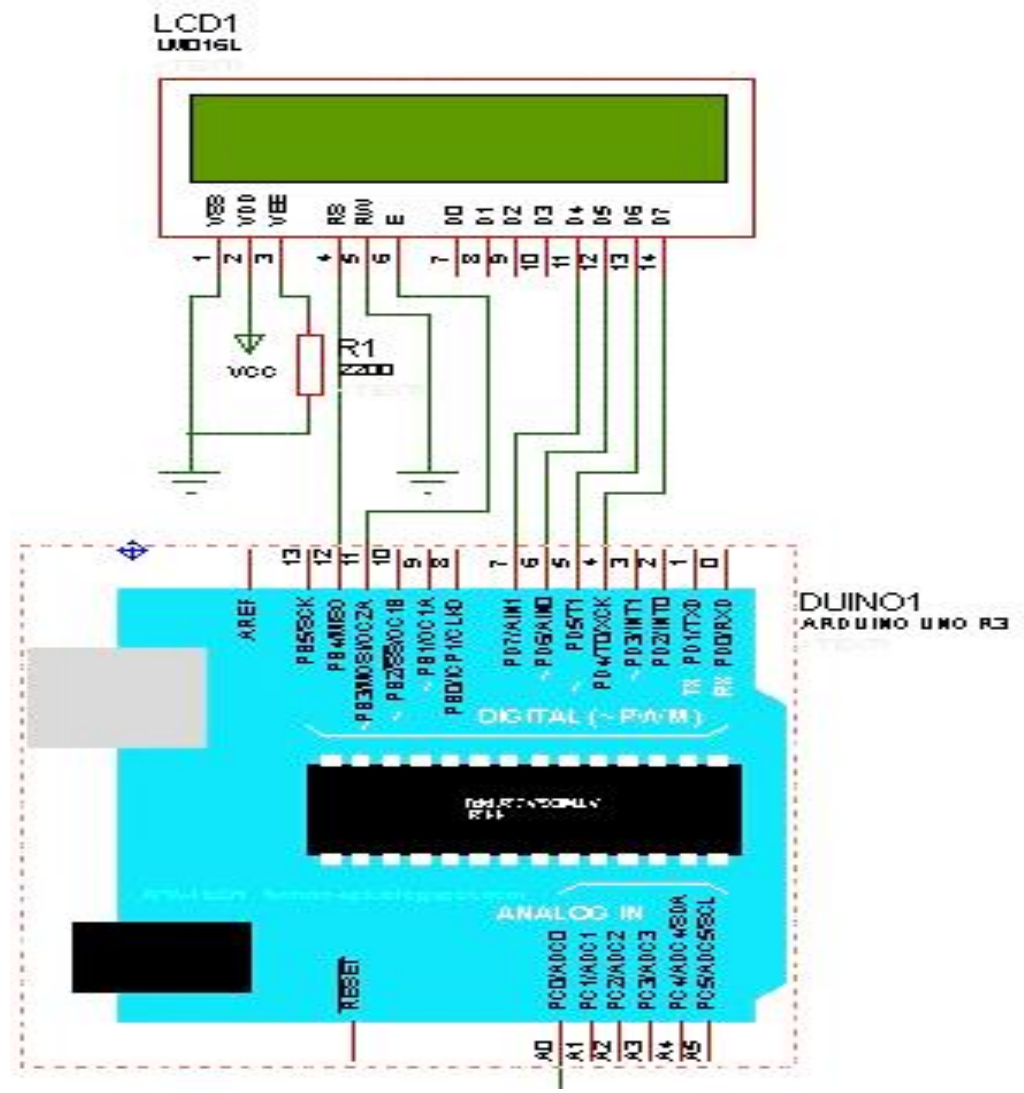

Gambar 4. Skematik Rangkain LCD (Liquid Crystal Display) $16 \times 2$

4. Masukkan kabel jumper ke vcc (Sensor Ultrasonik), kemudian hubungkan kabel jumper tersebut menuju Tegangan vcc Arduino sebagai sumber.

5. Masukkan kabel jumper ke ground (Sensor Ultrasonik), kemudian hubungkan kabel jumper tersebut menuju Tegangan ground Arduino sebagai sumber. 
6. Masukkan kabel jumper ke Trigger pada sensor ultrasonik kemudian masukkan kembali kabel jumper menuju Pin Digital No.9 pada Arduino Uno.

7. Masukkan kabel jumper ke Echo pada sensor ultrasonik kemudian masukkan kembali kabel jumper menuju Pin Digital No.8 pada Arduino Uno.

8. Program Arduino IDE seperti gambar dan keterangan koding berikut ini :

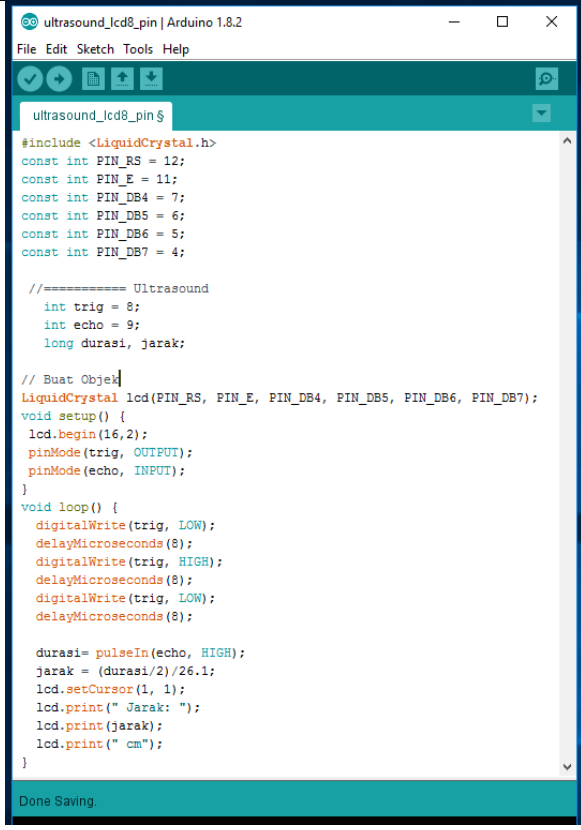

\#include <LiquidCrystal.h> const int PIN_RS = 12;

const int PIN_E = 11; const int PIN_DB4 = 7; const int PIN_DB5 = 6; const int PIN_DB6 = 5; const int PIN_DB7 = 4; $/ /==========$ Ultrasound int trig $=8$; int echo $=9$; long durasi, jarak; // Buat Objek LiquidCrystal Icd(PIN_RS, PIN_E, PIN_DB4, PIN_DB5, PIN_DB6, PIN_DB7); void setup() \{ Icd.begin(16,2); pinMode(trig, OUTPUT); pinMode(echo, INPUT); \} void loop() \{ 


\begin{tabular}{|l|l|}
\hline & digitalWrite(trig, LOW); \\
delayMicroseconds(8); & digitalWrite(trig, HIGH); \\
& delayMicroseconds(8); \\
digitalWrite(trig, LOW); & delayMicroseconds(8); \\
durasi=pulseln(echo, HIGH); & jarak =(durasi/2)/26.1; \\
Icd.setCursor(1, 1); \\
Icd.print(" Jarak: "); \\
Icd.print(jarak); \\
Icd.print(" cm"); \\
3 \\
\hline
\end{tabular}

9. Setelah memasukkan algoritma pada Arduino IDE maka Verifikasi Algoritma yang sudah anda buat agar bisa dideteksi kesalahan dalam penulisan programnya

10.Compail Algoritma pada modul Arduino agar bisa dilihat hasilnya pada LCD

11.Lihat jarak yang dibaca ultrasonik pada tampilan LCD dengan memberikan halangan buku/kertas pada sensor ultrasonik.

12. Bandingkan jarak yang terbaca oleh sensor ultrasonik dengan penggaris (alat standar).

13. Hitung selisi yang terbaca.

14.Isi tabel pengambilan data sebagai berikut : 


\begin{tabular}{|l|c|l|l|l|}
\hline No & $\begin{array}{c}\text { Jarak kertas } \\
\text { dengan ultrasound } \\
\text { (penggaris) }\end{array}$ & $\begin{array}{c}\text { Nilai jarak yang } \\
\text { terbaca di LCD }\end{array}$ & Selisi & $\begin{array}{c}\text { Ketepatan } \\
(\%)\end{array}$ \\
\hline 1 & $20 \mathrm{~cm}$ & & & \\
\hline 2 & $30 \mathrm{~cm}$ & & & \\
\hline 3 & $40 \mathrm{~cm}$ & & & \\
\hline 4 & $50 \mathrm{~cm}$ & & & \\
\hline 5 & $60 \mathrm{~cm}$ & & & \\
\hline
\end{tabular}

15.Gunakan Persamaan pengukuran ketepatan sebagai berikut:

Ketetapan $=p=|1-| \frac{Y_{n}-X_{n}}{X_{n}} \mid \times 100 \%$

Dimana : $Y n=$ Hasil pengukuran dengan penggaris

$\mathrm{Xn}=$ Nilai yang terbaca di LCD

\section{TUGAS}

1. Cobalah uji sensor ultrasonic dengan halangan benda padat, apakah sensor dapat mengirimkan informasi jarak pada LCD.

2. Cobalah uji sensor ultrasonic dengan halangan benda cairn (air dalam gelas) yang bening, apakah sensor dapat mengirimkan informasi jarak pada LCD. 
3. Hitung secara manual dengan ketepatan sensor ultrasound dalam membaca jarak halangan pada tabel langkah 4 diatas 


\section{BAB IV \\ RANGKAIAN I2C LCD 16x2}

\section{INSTRUMENTASI I2C LCD 16x2}

\section{a. TUJUAN}

Meminimalisir penggunaan pin Arduino untuk LCD 16x2 dengan memanfaatkan $12 \mathrm{C}$ dalam menampilkan karakter huruf maupun angka.

b. TEORI

\section{Konsep I2C Serial Bus}

Untuk menghubungkan antar processor atau controller dibutuhkan suatu system bus tertentu. Bus ini harus dapat melewatkan data atau parameter control antar processor yang berfungsi sebagai jaringan atau networking. Alasan penggunaan serial bus adalah implementasinya yang lebih mudah dalam sisi pengkabelan dan lebih mudah dari pada ada parallel bus. I2C serial bus dikembangkan oleh Philips sejak tahun 1980 ditunjukkan untuk pegaplikasian control dengan microkontroler. Pada dokumen resmi yang dikeluarkan oleh Philips semiconductor memiliki 3 buah kecepatan pada I2C serial bus, yakni $100 \mathrm{KHz}$ (Standard mode), 400 $\mathrm{KHz}$ (Fast-mode) dan $3.4 \mathrm{MHz}$ (Highspeed mode). Komunikasi pada I2C serial bus merupakan komunikasi serial sinkron, artinya data pada bus dikirim bit per bit (serial) dan clock ikut dikirimkan (sinkron). Sebagai saluran clock berupa SCL line. Dan satu buah saluran common ground sebagai referensi. (Mubarak T, Sumaryo, Abdurohman, 2008). 


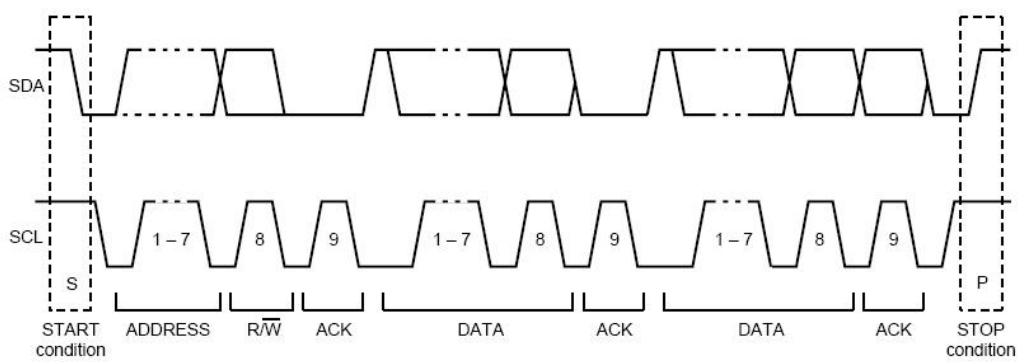

Gambar 1. Data transfer pada I2C serial bus. (Mubarak T, Sumaryo, Abdurohman, 2008)

Modul LCD I2C backpack interface ini meminimalisir jumlah pin mikrokontroler yang digunakan untuk mengendalikan LCD. Awalnya pakai 8/4 pin data, skarang cukup 2 yakni SCL dan SDA.

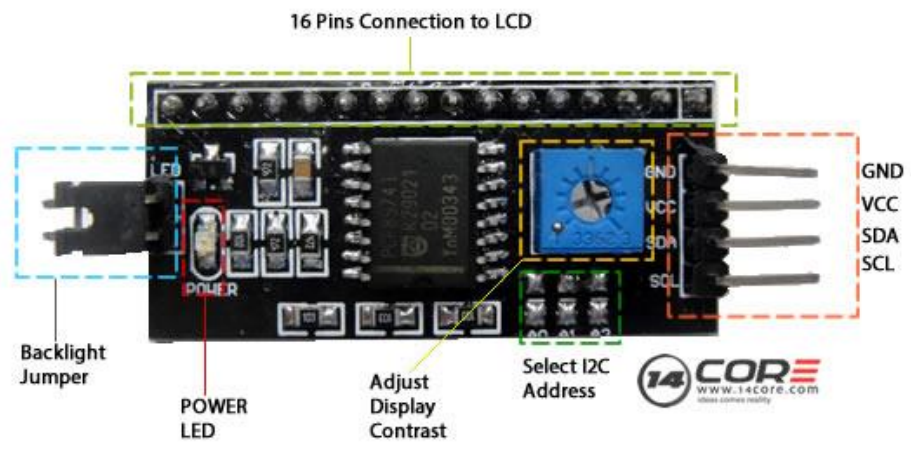

Gambar 2. Tampilan I2C

Material yang digunakan dalam latihan penggunaan $12 \mathrm{C}$ dapat dilakukan dengan cara berikut. 


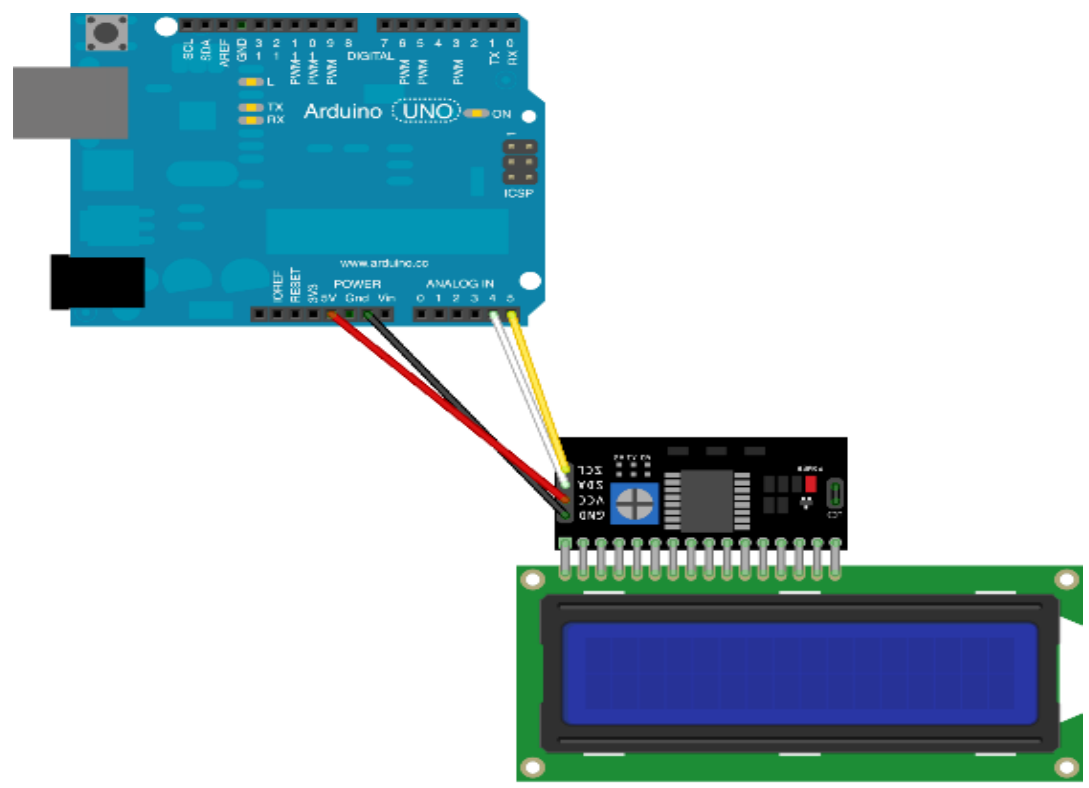

Gambar 3. Rangkaian I2C

1. Siapkan Arduino Uno sebelum merakit rangkaian I2C.

2. Siapkan LCD $16 \times 2$ dan $12 \mathrm{C}$.

3. Siapkan kabel jumper secukupnya untuk pemasangan $12 \mathrm{C}$ ke Arduino Uno.

4. Pasanglah $\mathrm{I} 2 \mathrm{C}$ ke dalam pin-pin LCD yang berjumlah 16 kaki.

5. Solder kaki I2C pada pin-pin LCD yang berjumlah 16 kaki.

6. Masukkan kabel jumper ke Ground pada I2C, kemudian masukkan kembali kabel jumper menuju Ground pada Arduino Uno.

7. Masukkan kabel jumper ke VCC pada 12C, kemudian masukkan kembali kabel jumper menuju VCC atau tegangan pada Arduino Uno. 
8. Masukkan kabel jumper ke SDA pada I2C, kemudian masukkan kembali menuju Pin Analog no. 4 pada Arduino Uno.

9. Masukkan kabel jumper ke SCL pada I2C, kemudian masukkan kembali menuju Pin Analog no. 5 pada Arduino Uno sebagaimana gambar berikut ini.

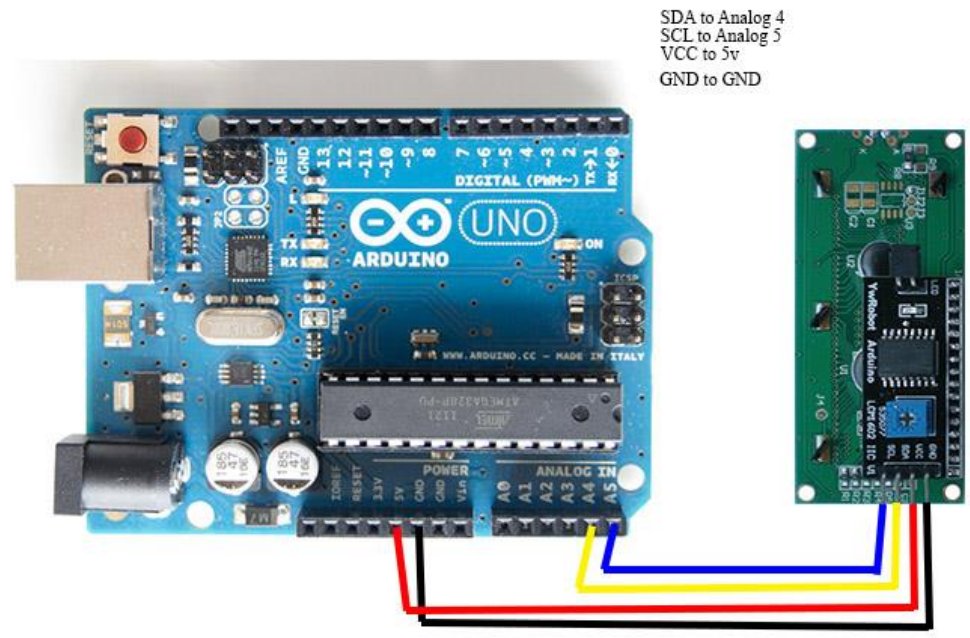

Gambar 4. Penempatan SDA dan SCL I2C ke Pin Analog Arduino

\section{* Persiapan secara Software Arduino IDE:}

1. Nyalakan komputer dan Buka Program Arduino IDE $\infty$

2. Scane dan isikan program Arduino dengan algoritma seperti Gambar 5 dibawah ini agar Arduino bisa dijalankan dengan I2C. Tanpa mengisikan program ini kedalam arduino, kemungkinan besar saat ngompail 
program yang diinginkan ke $12 \mathrm{C}$ akan gagal. Adapun programnya adalah sebagai berikut. Secara file.ino akan disediakan oleh asistan lab prodi teknik elektro (di file My Document dengan nama folder "Scane $12 C^{2}$ ").

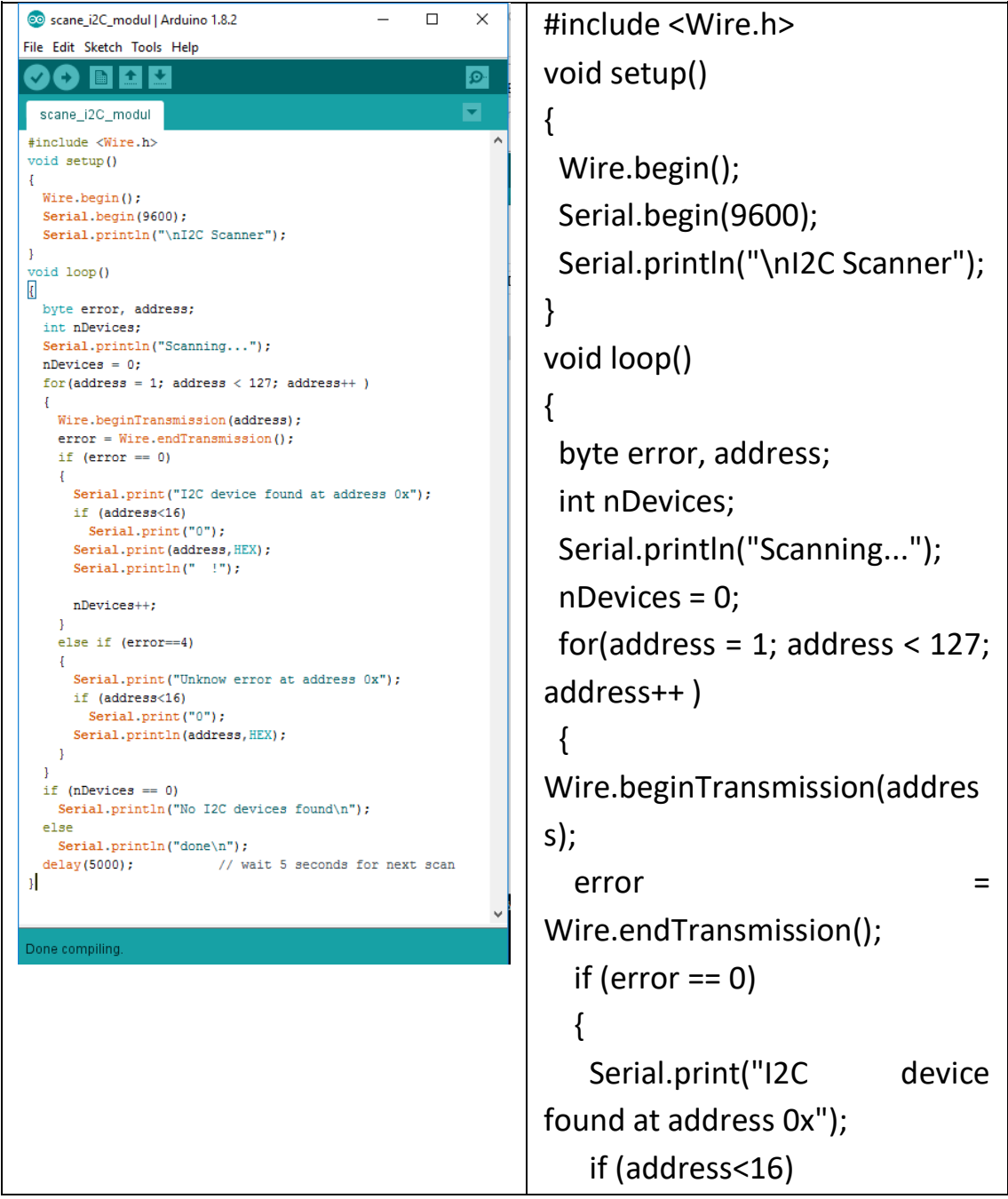




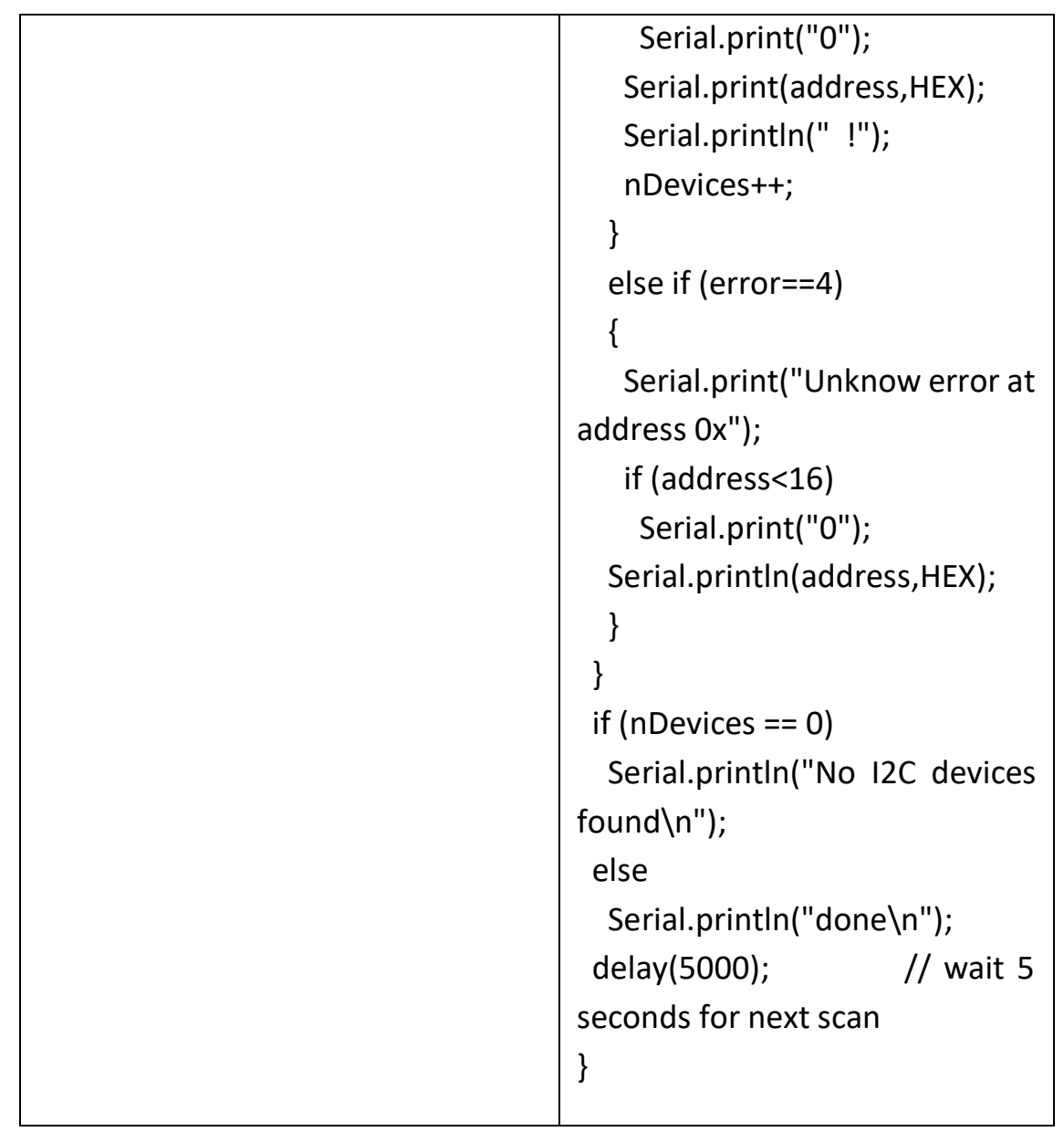

Gambar 5. Scane Arduino sebelum membuat karakter huruf atau angka pada LCD $16 \times 2$ menggunakan i2C

3. Setelah Algoritma sebagaimana gambar 5 diatas di Compail maka klik pada menu Tools $\rightarrow$ pilih Serial Monitor. Sehingga akan muncul gambar seperti berikut ini : 


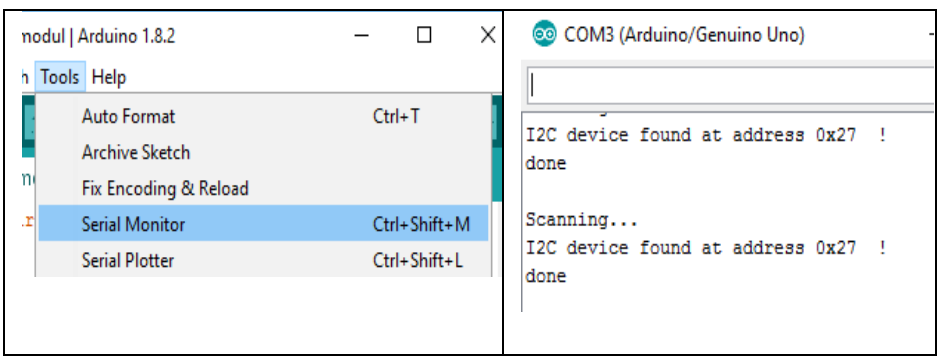

Gambar 6. Serial Monitor

4. Ketik Algoritma sebagaimana contoh pada Gambar 7a atau $7 b$ yang merupakan Algoritma dalam Menampilkan karakter di LCD 16×2 dengan i2C.

5. Setelah memasukkan algoritma pada Arduino IDE maka Verifikasi Algoritma yang sudah anda buat agar bisa dideteksi kesalahan dalam penulisan programnya

6. Compail Algoritma pada modul Arduino agar bisa dilihat hasilnya pada LCD i2C $16 \times 2$

7. Lihat hasilnya pada tampilan LCD. 


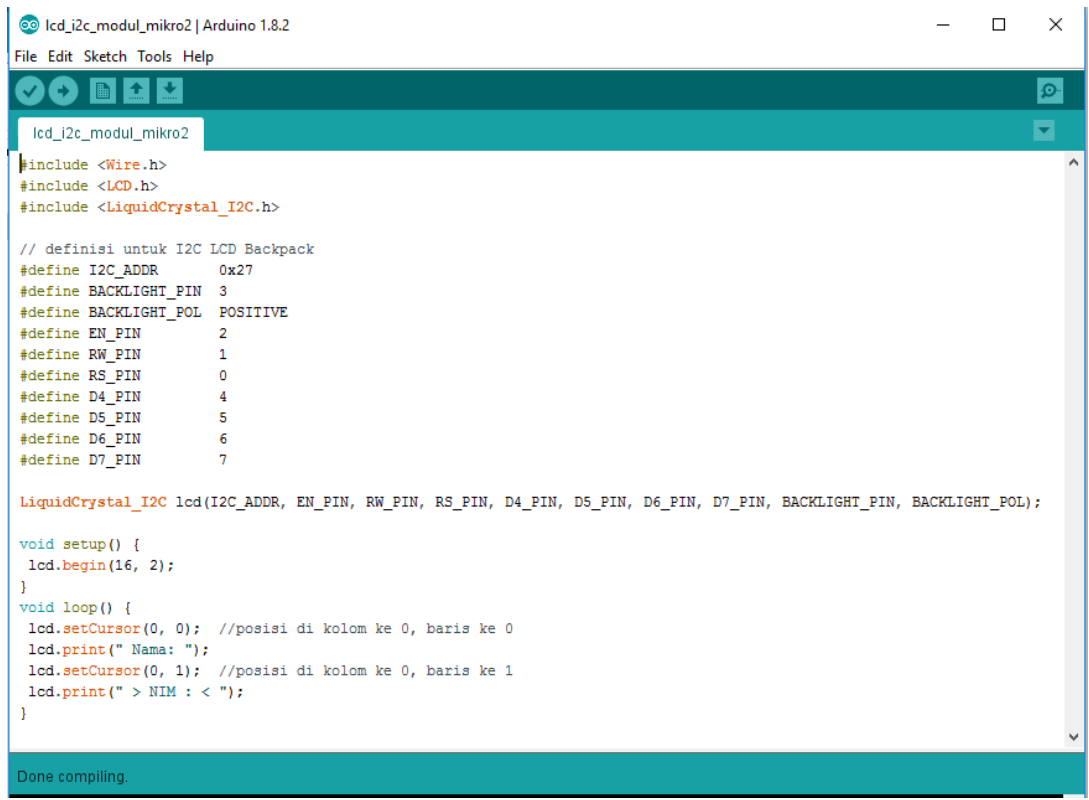

Gambar 7a. Algoritma pada IDE Arduino 


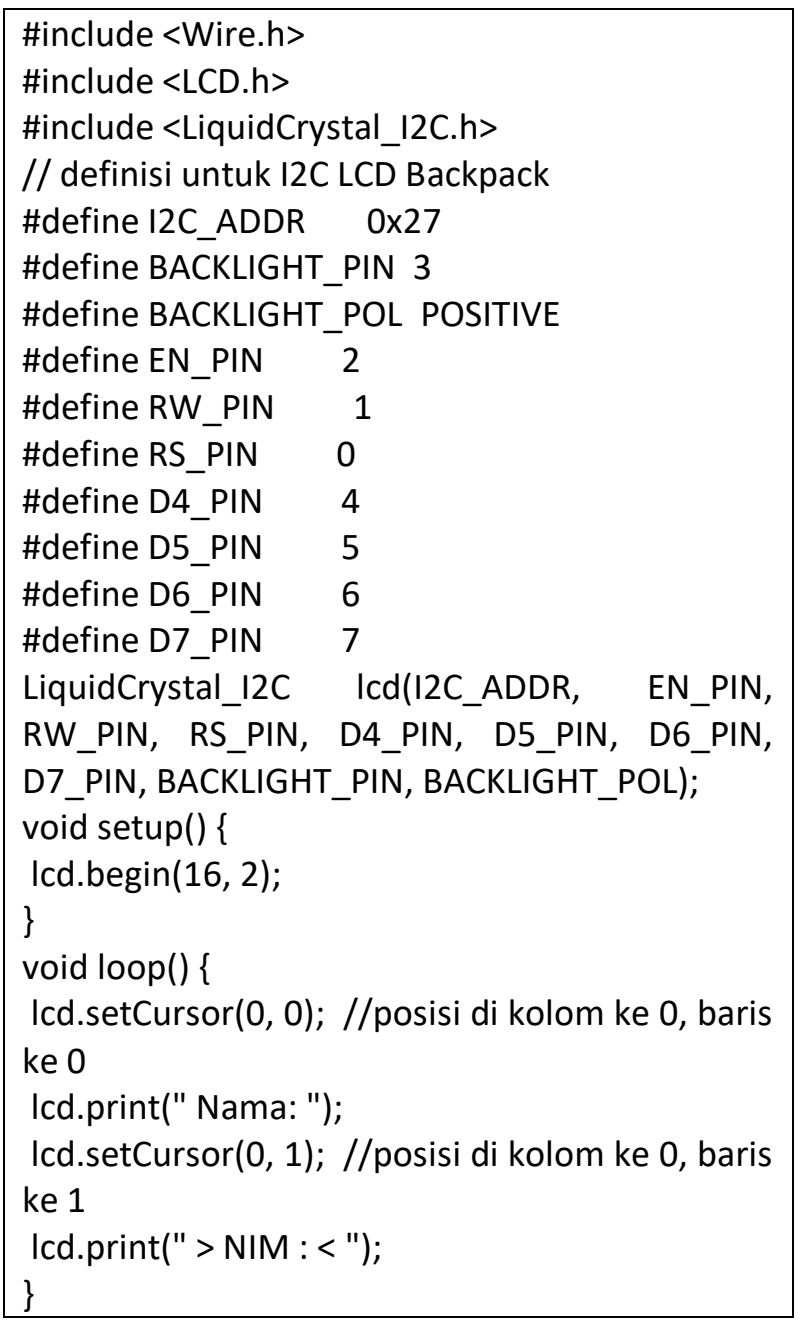

Gambar 7b. Algoritma pada IDE Arduino

8. Tulis karakter berdasarkan koordinat (kolom, Baris) untuk keterangan seperti sebagaimana tabel berikut ini, dan Foto Hasilnya untuk dimasukkan pada Laporan Praktikum. 


\begin{tabular}{|l|l|l|l|}
\hline No & $\begin{array}{l}\text { Koordinat } \\
\text { (Kolom, } \\
\text { Baris) }\end{array}$ & Karakter & Hasil Foto \\
\hline 1 & $(2,0)$ & Nama & \\
\hline 2 & $(1,1)$ & NIM & \\
\hline 3 & $(2,1)$ & Jurusan & \\
\hline 4 & $(0,0)$ & Institusi & \\
\hline 5 & $(5,1)$ & Hobi & \\
\hline
\end{tabular}

\section{TUGAS}

1. Buat Algoritma berjalan dari kiri ke kanan untuk Nama dan NIM pada LCD menggunakan Algoritma Utama dibawah ini : 


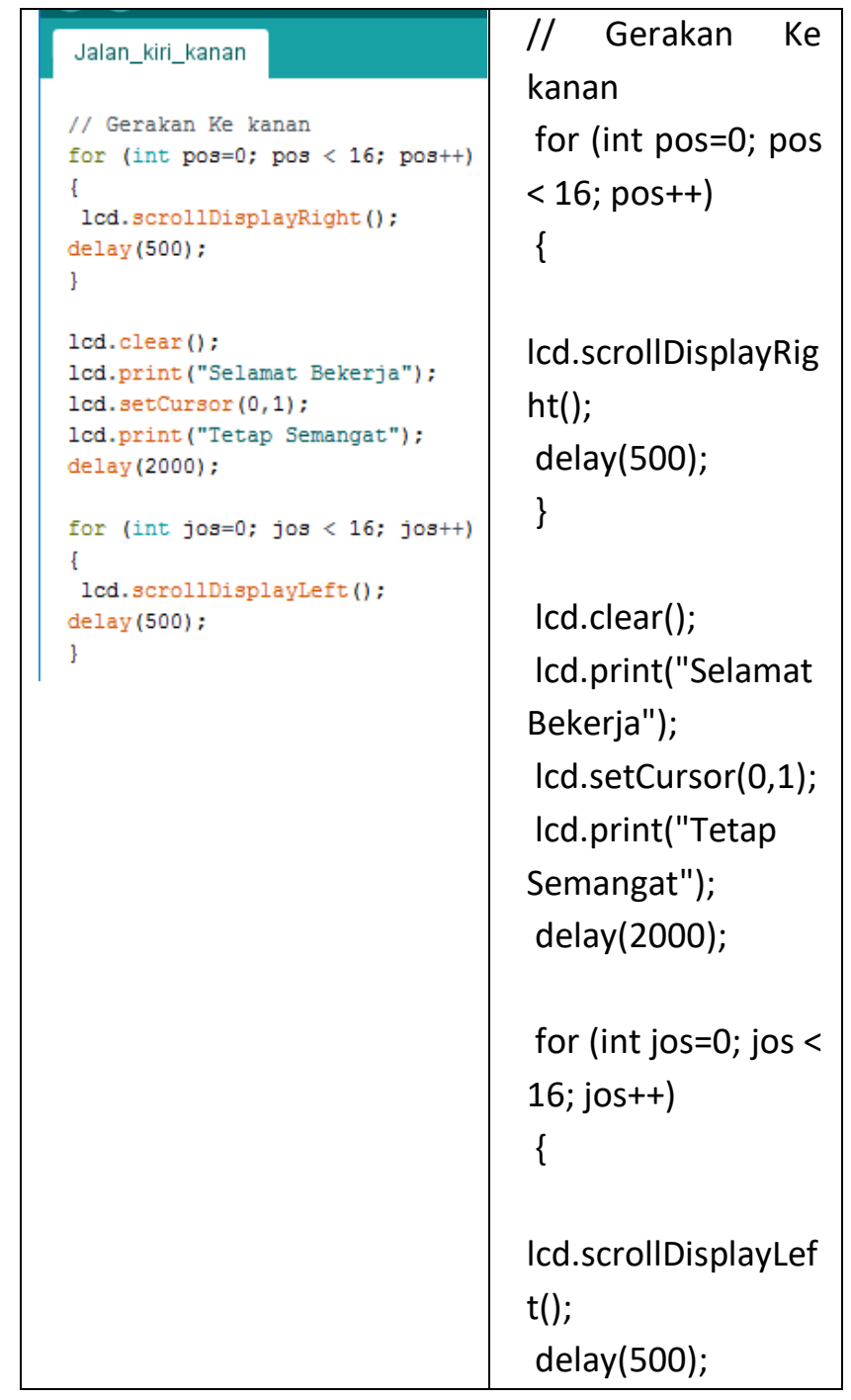




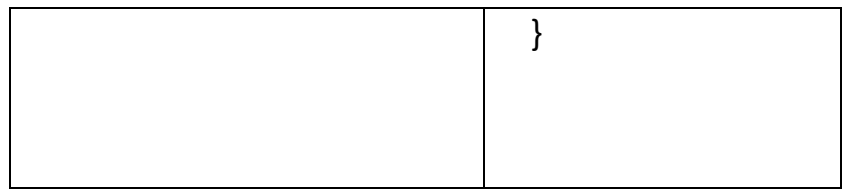

NB : Anda harus tetap mendeklarasikan sesuai panduan awal, karena Algoritma Utama di sini hanya program ini, bukan program keseluruhan. 


\section{BAB V \\ RANGAKAIAN SENSOR LM 35}

\section{SENSOR LM 35}

\section{A. TUJUAN}

Mendeteksi Suhu Ruangan dengan sensor LM 35.

B. TEORI

LM35 adalah komponen sensor suhu berukuran kecil seperti transistor (TO-92), komponen ini mampu mengukur suhu hingga $100^{\circ} \mathrm{C}$. Sensor suhu LM35 adalah komponen elektronika yang memiliki fungsi untuk mengubah besaran suhu menjadi besaran listrik dalam bentuk tegangan.

LM35 memiliki keakuratan tinggi dan kemudahan perancangan jika dibandingkan dengan sensor suhu yang lain, LM35 juga mempunyai keluaran impedansi yang rendah dan linieritas yang tinggi sehingga dapat dengan mudah dihubungkan dengan rangkaian kendali khusus seperti arduino, serta tidak memerlukan penyetelan lanjutan. Dengan tegangan keluaran yang terskala linear dengan suhu terukur,

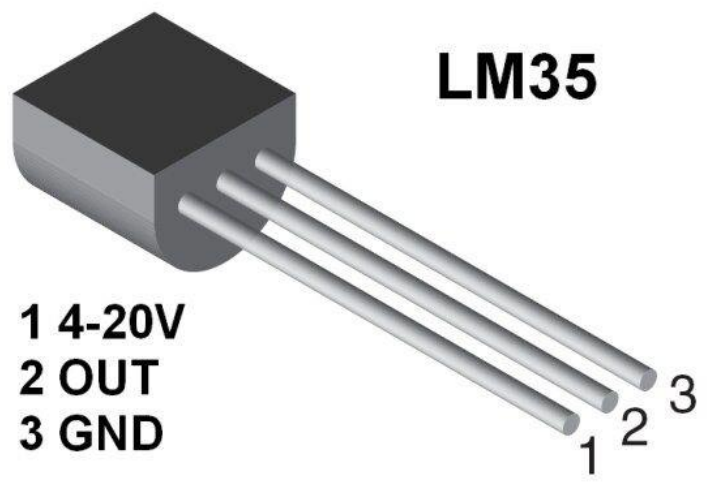

yakni 10 milivolt per 1 derajad celcius. 
Gambar 1. Sensor suhu LM 35 (Innovative, 2017)

Dari gambar diatas dapat diketahui bahwa sensor suhu IC LM35 pada dasarnya memiliki 3 pin diantaranya yaitu, pin 1 berfungsi sebagai sumber tegangan kerja dari LM35, pin 2 atau tengah digunakan sebagai tegangan keluaran atau $\mathrm{V}$ dengan jangkauan kerja dari 0 Volt sampai dengan 1,5 Volt dengan out tegangan operasi sensor LM35 yang dapat digunakan antar 4 Volt sampai 30 Volt. Keluaran sensor ini akan naik sebesar 10 $\mathrm{mV}$ setiap derajad celcius. Tegangan keluaran sensor yang terskala linear terhadap suhu terukur, yakni 10 milivolt per 1 derajad celcius. Jadi jika Vout $=530 \mathrm{mV}$, maka suhu terukur adalah 53 derajad Celcius. Dan jika Vout $=320 \mathrm{mV}$, maka suhu terukur adalah 32 derajad Celcius.

Simulasi Menampilkan Suhu di layar LCD dengan memakain LM 35 dapat dilakukan dengan cara sebagai berikut.

1. Siapkan Kit Arduino dan LCD 16×2; kabel jamper penghubung, dan sensor LM35. Gunakan gambar 2 Skematik Rangkain LCD sebagai ilustrasi dalam prakteknya 


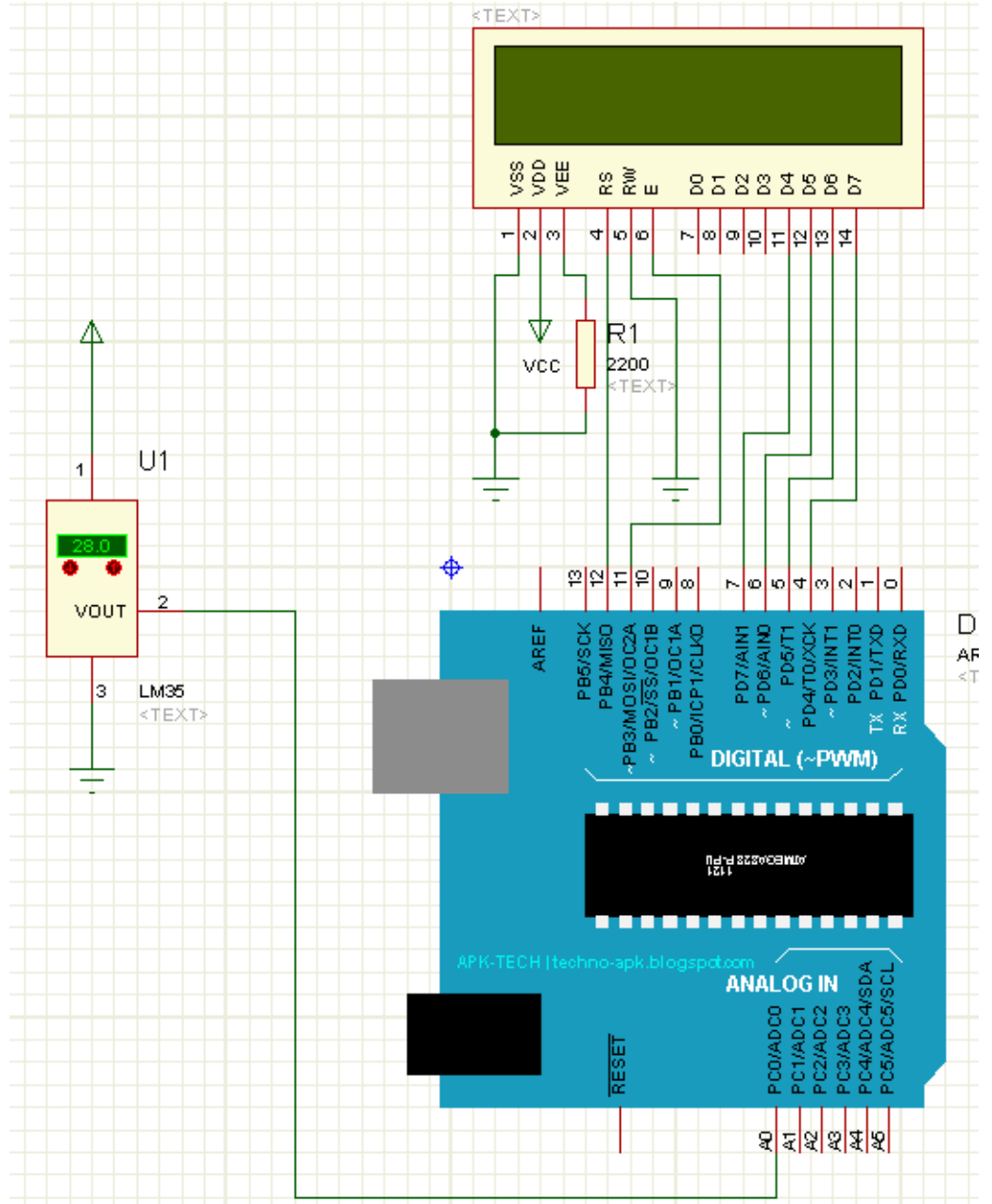

Gambar 2. Skematik Sensor Suhu LM35

2. Sensor suhu LM35 vout nya masuk ke pin alaog yaitu pin A0 pada arduino. 
3. Pemasangan jumper LCD sebagaimana Modul 4 (IV) pada petunjuk praktikum ini. Gunakan I2C untuk menampilkan nilai suhu di LCD $16 \times 2$.

4. Program Arduino IDE seperti gambar dan keterangan koding berikut ini :

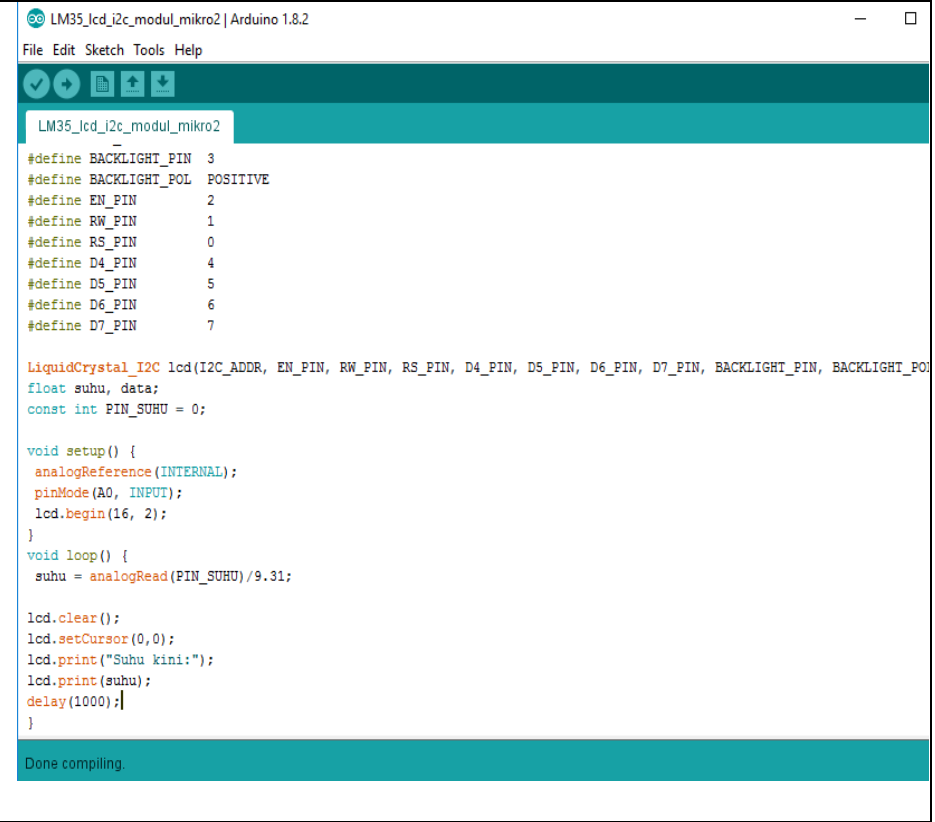

Gambar 3. Algoritma membaca suhu dengan LM35

\#include $<$ Wire.h $>$

\#include <LCD.h>

\#include <LiquidCrystal_I2C.h>

// definisi untuk I2C LCD Backpack

\#define I2C_ADDR $0 \times 27$ 


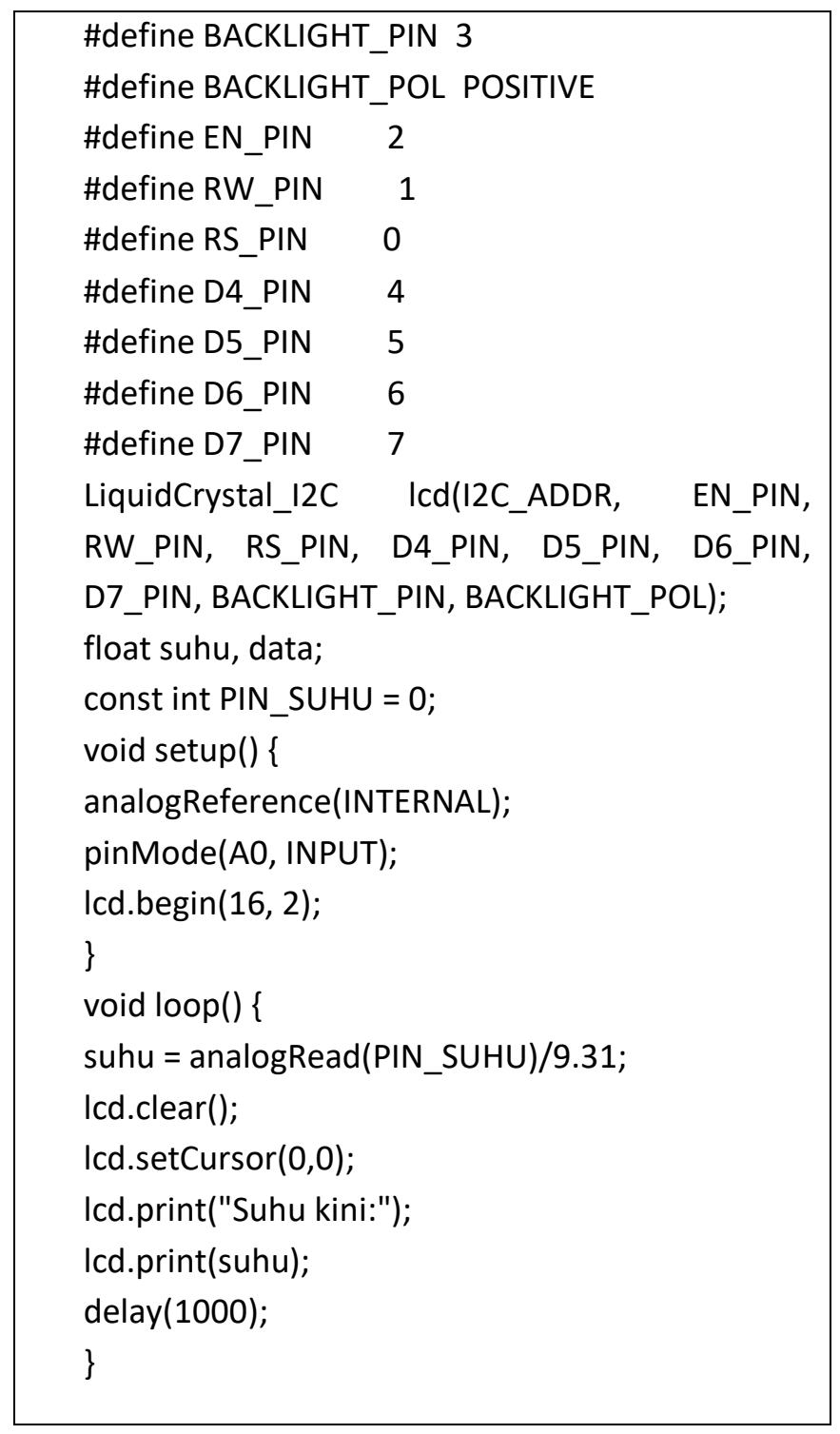

Gambar 4. Algoritma membaca suhu dengan LM35 
5. Setelah memasukkan algoritma pada Arduino IDE maka Verifikasi Algoritma yang sudah anda buat agar bisa dideteksi kesalahan dalam penulisan programnya

6. Compail Algoritma pada modul Arduino agar bisa dilihat hasilnya pada LCD

7. Lihat suhu yang dibaca LM35 pada tampilan LCD dengan mendekatkan pada kondisi panas (korek api/lilin) sebagai variabel.

8. Bandingkan suhu yang terbaca oleh sensor ultrasonik dengan Termometer Infrared (alat standar).

9. Hitung selisi yang terbaca.

10.Isi tabel pengambilan data sebagai berikut :

\begin{tabular}{|l|l|l|l|l|}
\hline No & Suhu LM35 $\left({ }^{\circ} \mathrm{C}\right)$ & $\begin{array}{l}\text { Nilai Suhu pada } \\
\text { alat Standar }\left({ }^{\circ} \mathrm{C}\right)\end{array}$ & Selisi & Ketepatan (\%) \\
\hline 1 & 10 detik pertama & & & \\
\hline 2 & 5 detik kedua & & & \\
\hline 3 & 5 detik ketiga & & & \\
\hline 4 & 5 detik keempat & & & \\
\hline 5 & 5 detik kelima & & & \\
\hline
\end{tabular}

11.Gunakan Persamaan pengukuran ketepatan sebagai berikut : 
Ketetapan $=p=|1-| \frac{Y_{n}-X_{n}}{X_{n}}|| \times 100 \%$

Dimana: $\mathrm{Yn}=$ Hasil pengukuran suhu dengan Alat Standar $\left({ }^{\circ} \mathrm{C}\right)$

$$
\mathrm{Xn}=\text { Nilai suhu yang terbaca di } \mathrm{LCD}\left({ }^{\circ} \mathrm{C}\right)
$$




\section{TUGAS}

1. Cobalah uji sensor LM35 dengan suhu tubuh anda dengan cara memegang LM35, apakah sensor dapat mengirimkan informasi suhu pada LCD.

2. Hitung secara manual pada laporan praktikum anda ketepatan sensor LM35 dalam membaca suhu pada tabel langkah 10 diatas. 


\section{BAB VI \\ RANGKAIAN RELAY}

\section{RELAY}

\section{B. TUJUAN}

Membuat, mengontrol aplikasi dan menguji pembuatan instrument arduino dengan menerapkan komponen relay.

c. TEORI

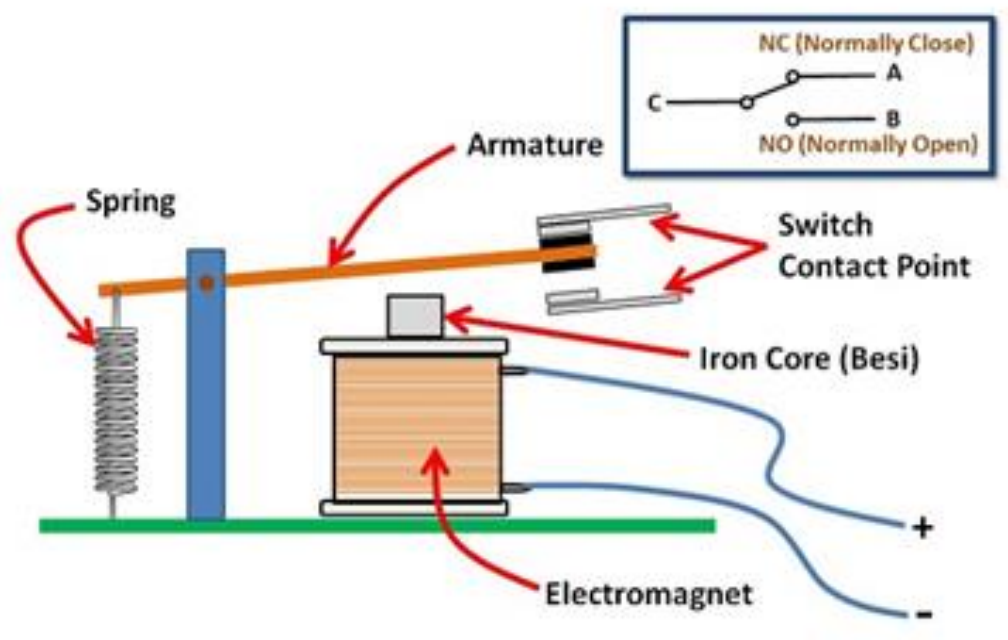

Gambar 1. Struktur sederhana Relay

Relay merupakan suatu Saklar (Switch) elektromagnetik yang apabila kumparan pada relay di aliri arus listrik dapat membuat Inti Besi (Iron Core) menjadi magnet sehingga dapat menarik kontak (Armatur) jika gaya magnet yang dihasilkan menjadi lebih besar dari pada gaya pegas (spring) yang ada sebagaimana ilustrasi pada gambar (aziz, 2009). Relay yang menggunakan Elektromagnet $5 \mathrm{~V}$ dan 50 
mA mampu menggerakan Armature Relay (yang berfungsi sebagai saklarnya) untuk menghantarkan listrik 220V 2A. Berdasarkan pada Gambar diatas Kontak Poin Relay terdiri dari 2 jenis yaitu :

- Normally Close (NC) yaitu kondisi awal sebelum diaktifkan akan selalu berada di posisi CLOSE (tertutup)

- Normally Open (NO) yaitu kondisi awal sebelum diaktifkan akan selalu berada di posisi OPEN (terbuka)

Pada gambar diatas apabila Kumparan Coil dilewati arus listrik, maka akan timbul gaya Elektromagnet yang akan menarik Armature untuk berpindah dari Posisi sebelumnya (NC) ke posisi baru (NO), sehingga Saklar dapat menghantarkan arus listrik di posisi (NO). Sehingga Posisi awal Armature sebelumnya (NC) menjadi tidak terhubung. Begitu sebaliknya ketika Kumparan Coil tidak dialiri arus listrik maka Armature akan kembali lagi ke posisi Normally Close (NC). Arus listrik yang dibutuhkan dalam memindahkan kontak dari NC ke NO relatif kecil. Perlu diketahui bahwa Relay ada yang aktif Low dan aktif High. Maksudnya aktif Low adalah relay akan aktif jika diberi masukan LOW atau nol, sedangkan aktif High adalah relay akan aktif jika diberi masukan HIGH atau satu.

Berikut ini Contoh gambar pemasangan Relay 2 Chanel pada Arduino UNO untuk menyalakan dan mematikan Lampu. 


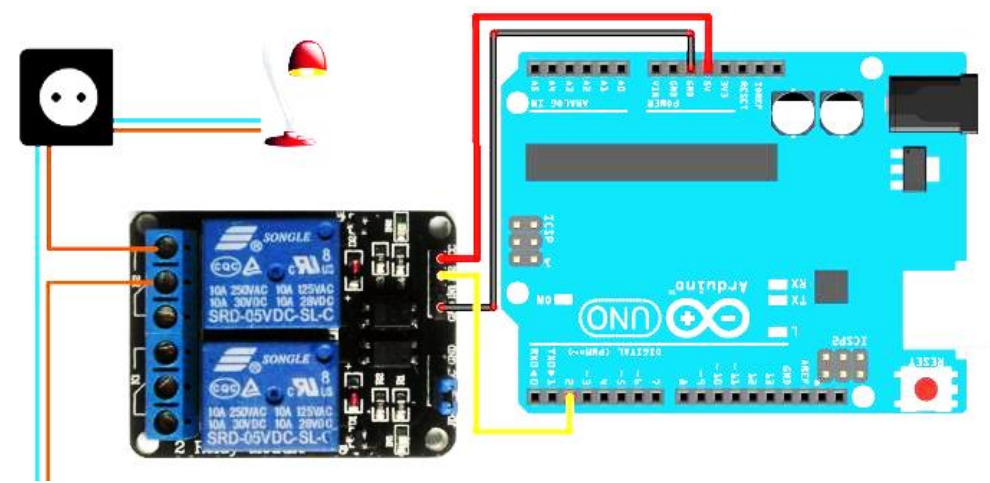

Gambar 2. Pemasangan Relay 2 Chanel pada Arduino UNO

Simulasi Menghidupkan Relay dengan Arduino dapat dilakukan dengan cara sebagai berikut.

1. Siapkan Arduino Uno sebelum merakit Motor DC.

2. Gunakan Lampu AC sesuai dengan tegangan yang sudah ditentukan.

3. Lampu AC pada praktikum ini akan digerakkan dengan bantuan Supplay Tegangan \pm 12 Volt sehingga butuh relay dalam pengoprasiannya. Relay yang digunakan pada praktikum ini adalah tipe relay Aktif LOW. Sehingga Masukkan kabel jumper warna merah pada Normally Close (NC) dan Normally Open (NO) supplay tegangan \pm 12 Volt untuk menyalakan lampu seperti gambar dibawah ini. Taruh kabel hitam Lampu AC pada ground. 


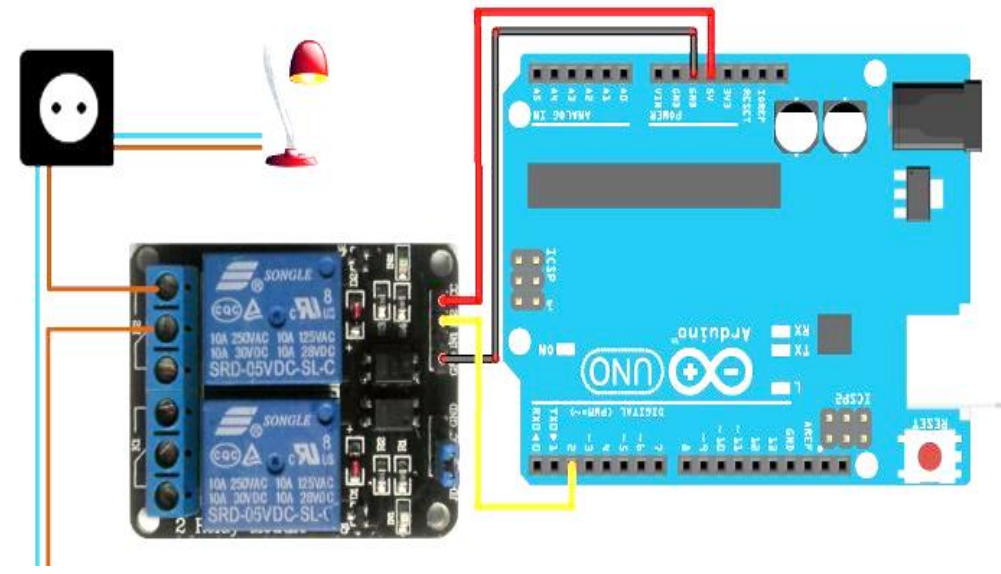

Gambar 3. Contoh Pemasangan Relay 2 Chanel pada Arduino UNO

4. Karena Lampunya ada 2 maka ulangi langkah 3 untuk menyalakan lampu lainnya.

5. Masukkan kabel jumper pada Pin 12 Arduino (digital) dan hubungkan pin tersebut ke pin masukan (Input) Relay 4 Chanel.

6. Masukkan kabel jumper pada Pin 11 Arduino (digital) dan hubungkan pin tersebut ke pin masukan (Input) Relay 4 Chanel.

7. Masukkan Ground Relay 4 Chanel ke ground Arduino Uno. Serta Masukkan supplay (vcc) Relay 4 Chanel ke vcc Arduino Uno.

8. Program Arduino IDE seperti coding dibawah ini : 


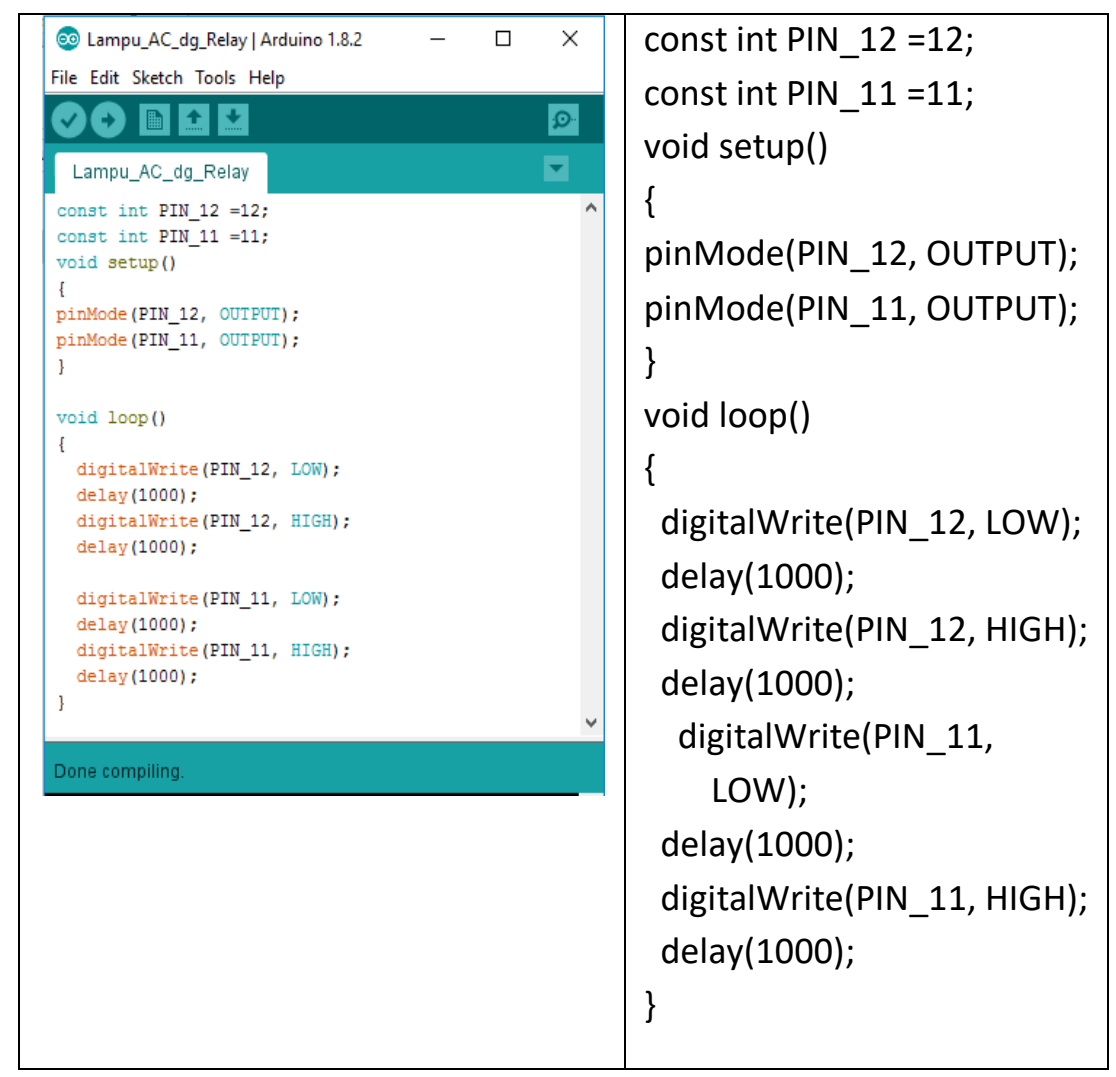

Gambar 4. Algoritma Nyalakan lampu AC dengan Relay

9. Setelah memasukkan algoritma pada Arduino IDE maka Verifikasi Algoritma yang sudah anda buat agar bisa dideteksi kesalahan dalam penulisan programnya

10.Compail Algoritma pada modul Arduino agar bisa dilihat hasilnya pada putaran motor

11.Isi tabel berikut ini untuk menggerakkan Motor jika ketentuannya sebagai berikut : 


\begin{tabular}{|l|c|c|c|l|}
\hline No & $\begin{array}{c}\text { Posisi PIN } \\
\text { Arduino }\end{array}$ & Delay & $\begin{array}{c}\text { Kondisi } \\
\text { lampu } \\
\text { (nyala/Tidak) }\end{array}$ & Foto Hasil \\
\hline 1 & Pin 13 & 2000 & & \\
\hline 2 & Pin 9 & 1000 & & \\
\hline 3 & Pin 6 & 1500 & & \\
\hline 4 & Pin 2 & 2500 & & \\
\hline 5 & Pin 4 & 1000 & & \\
\hline
\end{tabular}

\section{TUGAS}

1. Apakah Lampu AC dapat menyala dengan baik jika kabel jamper antara relay dengan arduino dimasukkan di Pin Analog Arduino (AO) ?

2. Apa alat ukur yang digunakan untuk mengukur kekuatan cahaya lampu ? dan apa satuannya? 


\section{BAB VII \\ Sensor MAX30100}

\section{Sensor MAX30100}

\section{A. TUJUAN}

Memahami Prinsip Kerja Sensor MAX30100, dan mampu memprogram dan mengoprasikan sensor MAX30100 pada Instrumentasi Medis.

\section{B. TEORI}

Sensor MAX30100 adalah sensor kesehatan memanfaatkan sensor optik yang terintegrasi antara IR dan LED merah yang dikombinasikan dengan photodetector, serta pemrosesan sinyal analog rendah untuk mendeteksi dan mengukur oksimetri denyut nadi dan sinyal detak jantung melalui salah satu ujung jari tangan.

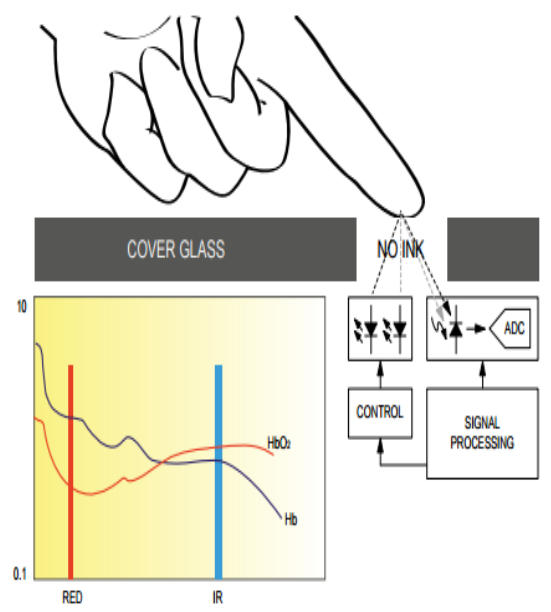

Gambar 1. Sistem Blok Diagram MAX30100 
Cara kerja sensor ini adalah dari pancaran dua LED yang berwarna merah yang menghasilkan dua panjang gelombang cahaya, kemudian inframerah mengukur absorbansi darah berdenyut melalui fotodetektor yang menghasilkan pembacaannya. Pembacaan sensor akan tidak maksimal apabila banyak melakukan pergerakan dan terlalu banyak tekanan pada jari tangan maupun sensor mengakibatkan menyempitnya aliran darah kapiler oleh karena itu dapat mengurangi kehandalan pembacaan data pada sensor.

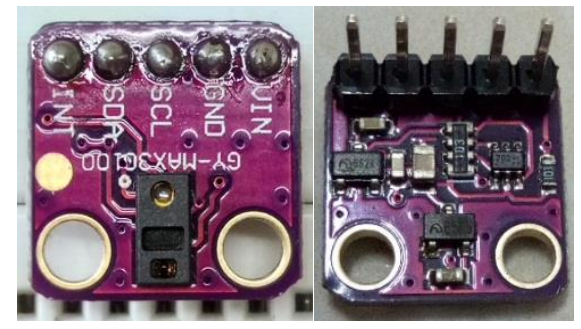

Gambar 2. Sensor MAX30100 (Rizal, 2018)

Tabel 1. Spesifikasi Sensor MAX30100

\begin{tabular}{|c|c|c|}
\hline No. & Fitur & Keterangan \\
\hline 1. & Tegangan Operasi & 5 Volt \\
\hline 2. & Arus Operasi & $3 \mathrm{~mA}$ \\
\hline 3. & Protokol Komunikasi & I2C (SDA dan SCL) \\
\hline 4. & Kerja Sensor & $\begin{array}{l}\text { - Saturasi Oksigen dalam Darah } \\
\left(\mathrm{SpO}^{2}\right) \\
\text { - } \text { Heart Rate }(\mathrm{bpm}) \\
\text { - } \text { Suhu Object }\left({ }^{\circ} \mathrm{C}\right)\end{array}$ \\
\hline 5. & Dimensi & $14 \mathrm{~mm} \times 14 \mathrm{~mm}$ \\
\hline
\end{tabular}

Pada rangkaian sensor MAX30100 ini juga menggukan sumber tegangan pada modul powerbank 1 slot. Sensor ini 
dilengkapi juga dengan rangkaian $A D C$ sehingga data yang dikeluarkan berupa data digital, oleh karena itu data yang dikirimkan ke arduino nano memanfaatkan pin SDA dan SCL juga.

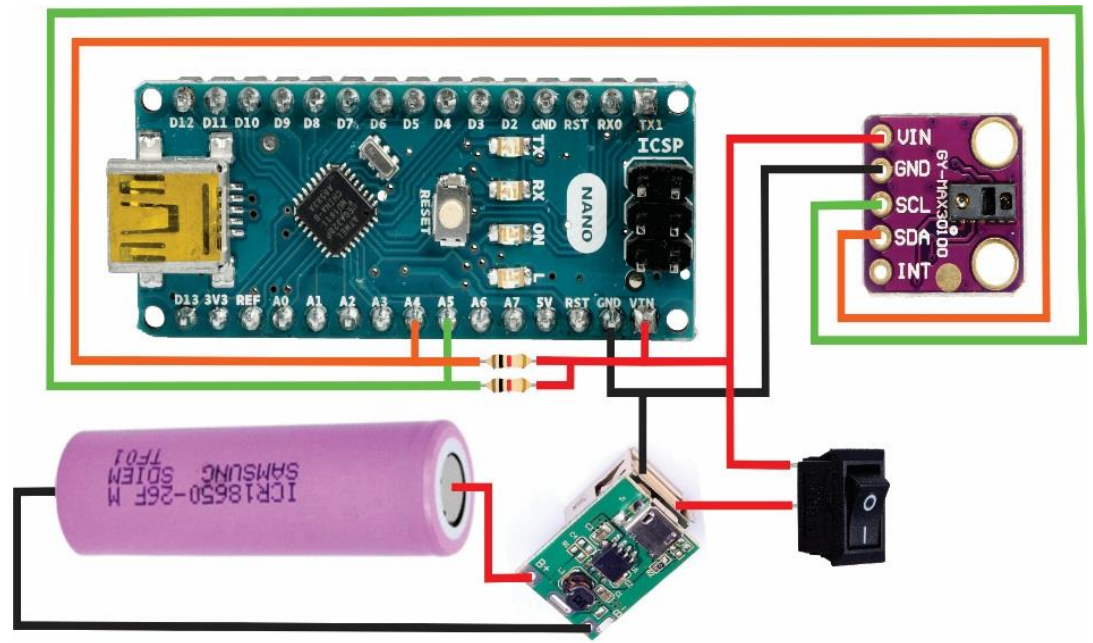

Gambar 3. Rangkaian Sensor MAX30100 (Rizal, 2018)

Pada Gambar 3. rangkaian sensor MAX30100 dengan mikrokontroler arduino nano diatas dengan port yang terhubung adalah pin SDA sensor MAX30100 dihubungkan pada pin A4 arduino nano, sedangkan pin SCL sensor MAX30100 dihubungkan ke pin A5 arduino nano. Untuk tabel dari rangkaian sensor MAX30100 dapat dilihat pada Tabel 2.

Tabel 2 Pengalamatan Pin Rangkaian Keseluruhan

\begin{tabular}{|c|c|c|c|}
\hline $\begin{array}{c}\text { No } \\
\cdot\end{array}$ & $\begin{array}{c}\text { Alamat Port } \\
\text { Arduino }\end{array}$ & $\begin{array}{c}\text { Alamat Port } \\
\text { Alat }\end{array}$ & $\begin{array}{c}\text { Hardware } \\
\text { Sensor }\end{array}$ \\
\hline 1 & SDA & SDA & \\
\hline
\end{tabular}




\begin{tabular}{|c|c|c|c|}
\hline 2 & $\mathrm{SCL}$ & $\mathrm{SCL}$ & \multirow{3}{*}{$\begin{array}{c}\text { Sensor } \\
\text { MAX30100 }\end{array}$} \\
\hline 3 & VCC 5v Eksternal & VCC & \\
\hline 4 & GND & GND & \\
\hline
\end{tabular}

\section{Tabel Pemrograman}

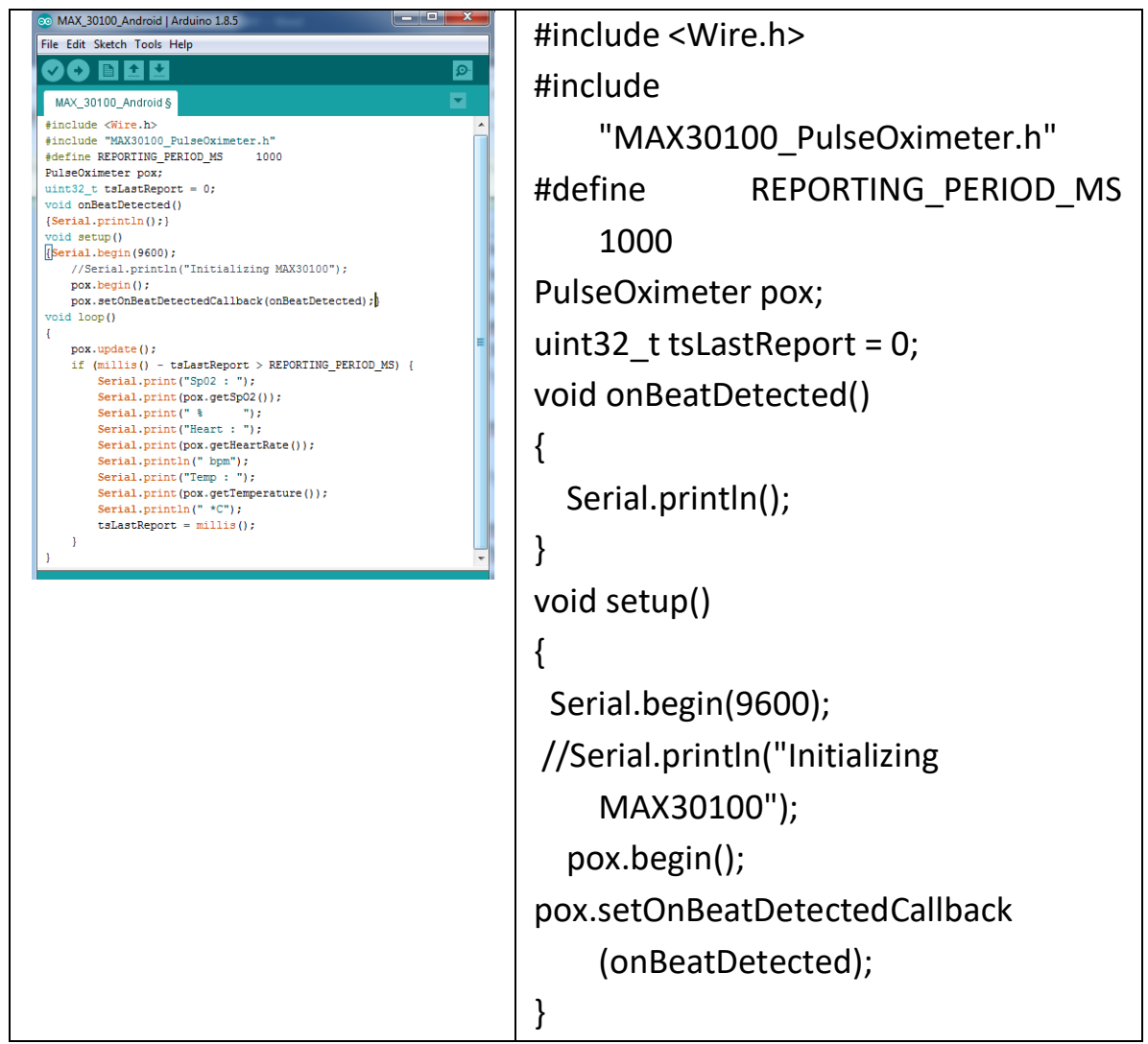




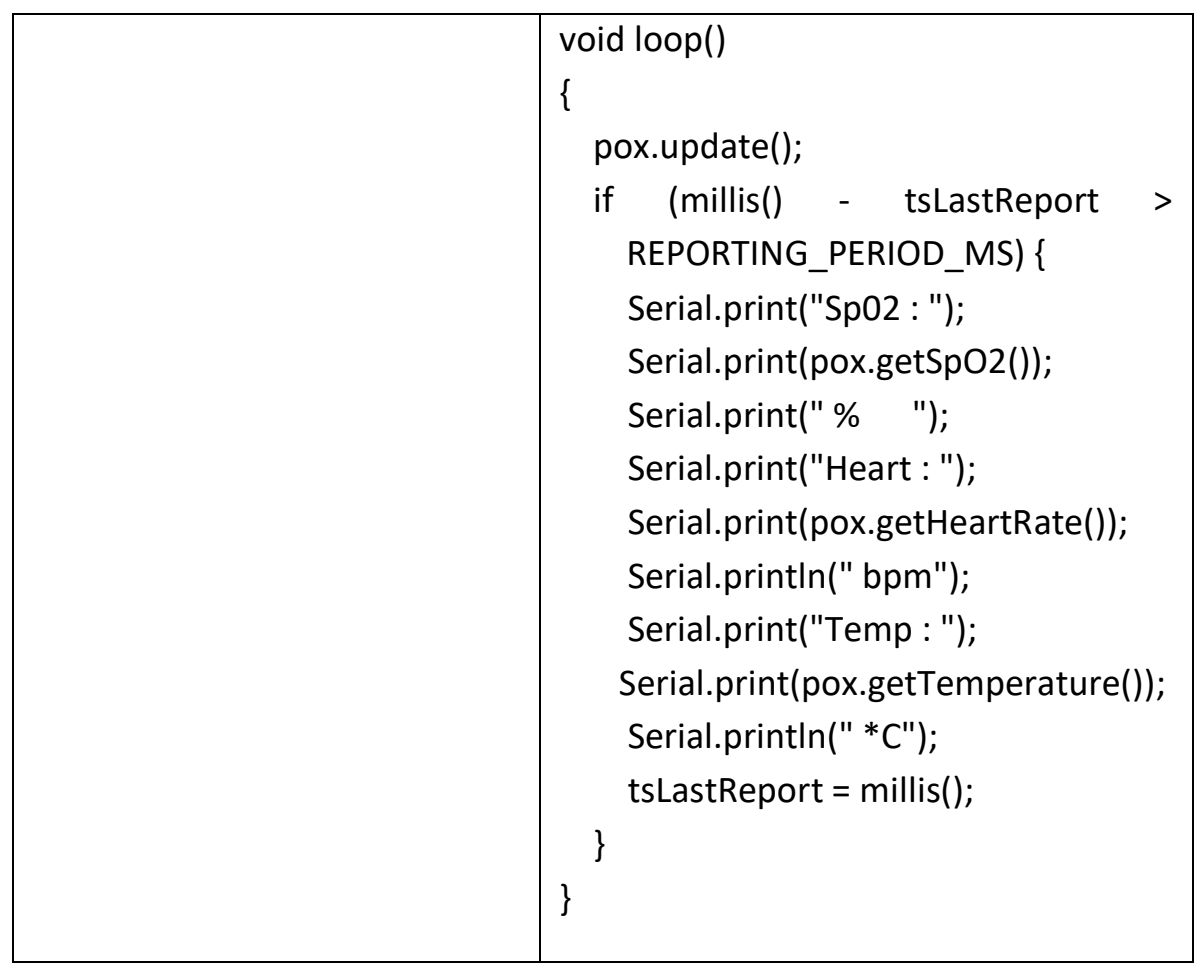

\section{TUGAS}

1. Jalankan pemrograman Sensor MAX30100 menggunakan LCD 16x2

2. Tampilkan nilai Sensor MAX30100 di Smartphone Android menggunakan Komunikasi Bluetooth. 


\section{BAB VIII \\ Sensor Suhu DS18B20}

\section{A. TUJUAN}

Memahami Prinsip Kerja Sensor DS18B20, dan mampu memprogram dan mengoprasikan sensor DS18B20 pada Instrumentasi Medis.

\section{B. TEORI}

Sensor DS18B20 adalah sensor untuk mengukur suhu badan manusia yang memiliki akurasi nilai dan kestabilan lebih baik dari sensor Lm35. DS18B20 adalah sensor suhu digital atau untuk pembacaan suhu,sensor ini tahan air dikarenakan sensor terlondungi oleh cashing waterproof serta memilki 3 pin yang terdiri dari vcc, Ground dan Data Input/Output. Berikut konfigurasi pin Ds18b20.

Tabel 1. Konfigurasi Pin Sensor DS18B20

\begin{tabular}{|l|l|l|}
\hline No & Nama Pin & Fungsi Pin \\
\hline 1 & Merah & Sumber tegangan 5 volt dc \\
\hline 2 & Hitam & 0 volt dc / Ground \\
\hline 3 & Kuning & Input Sensor \\
\hline
\end{tabular}

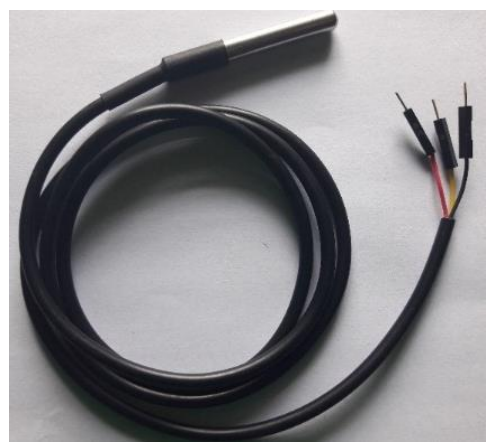


Gambar 2. Sensor DS18B20

Tabel 3. Spesifikasi Sensor DS18B20

\begin{tabular}{|l|l|l|}
\hline No & Fitur & Keterangan \\
\hline 1 & Tegangan & 5 VDC \\
\hline 2 & Arus & $1 \mathrm{~mA}$ \\
\hline 3 & Jumlah Pin & $3 \mathrm{Pin}$ \\
\hline 4 & Deteksi Temperatur & $-1.5^{\circ} \mathrm{C}$ sampai $125^{\circ} \mathrm{C}$ \\
\hline 5 & $\begin{array}{l}\text { Min. Deteksi } \\
\text { Temperatur }\end{array}$ & $-55^{\circ} \mathrm{C}$ \\
\hline 6 & $\begin{array}{l}\text { Maks. Deteksi } \\
\text { Temperatur }\end{array}$ & $125^{\circ} \mathrm{C}$ \\
\hline 7 & Akurasi & $0.5^{\circ} \mathrm{C}$ \\
\hline
\end{tabular}

Tabel 3 diatas menerangkan tentang spesifikasi sensor DS18B20 untuk mempermudah mengetahui dalam menggunakan sensor DS18B20 ini. Sehingga tidak sampai merusak sensor jika salah penggunaannya. Dikarenakan sudah terdapat batasan-batasan tegangan sensor. Sensor Ds18b20 adalah sebuah sensor yang dapat digunakan untuk pengukuran suhu. DS18B20 merupakan sebuah sensor suhu dimana akurasi nilai suhu dan kecepatan pengukuran memiliki kestabilan yang jauh lebih baik dari sensor LM35DZ. Pada rangkaian sensor DS18B20 ini menggunakan sumber tegangan 5 Volt yang didapat dari power suply pada pin Vin. 


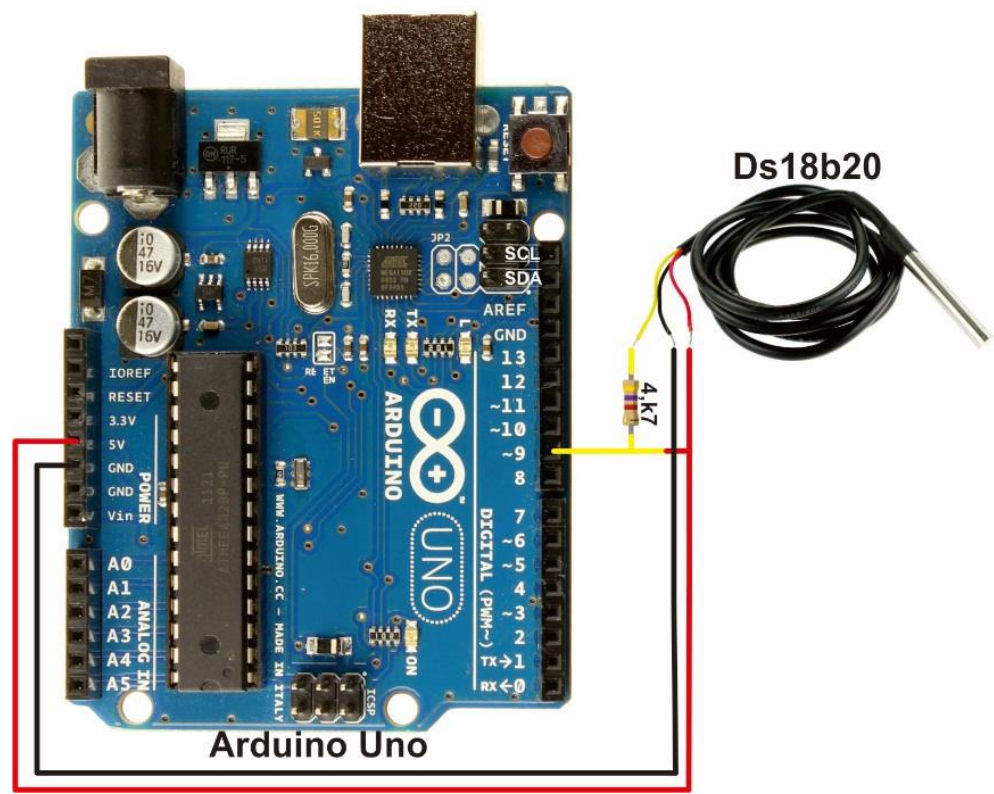

Gambar 3. Rangkaian Arduino Uno dengan Sensor Ds18b20

Dari Gambar 3. Rangkaian sensor ds18b20 dengan mikrokontroller arduino, dengan rangkaian skematik diatas dapat diketahui port yang terhubung adalah Port digital atau PD9 arduino untuk dihubungkan ke input sensor ds18b20. 
Tabel 4. Pengalamatan Port Microcontroller Arduino dengan Rangkaian Sensor Ds18b20

\begin{tabular}{|l|l|l|}
\hline No. & Alamat Port Arduino & Alamat Port Alat \\
\hline 1. & PD 9 & INPUT SENSOR \\
\hline 2. & VCC 5 Volt & VCC \\
\hline 3. & GND & GND \\
\hline
\end{tabular}

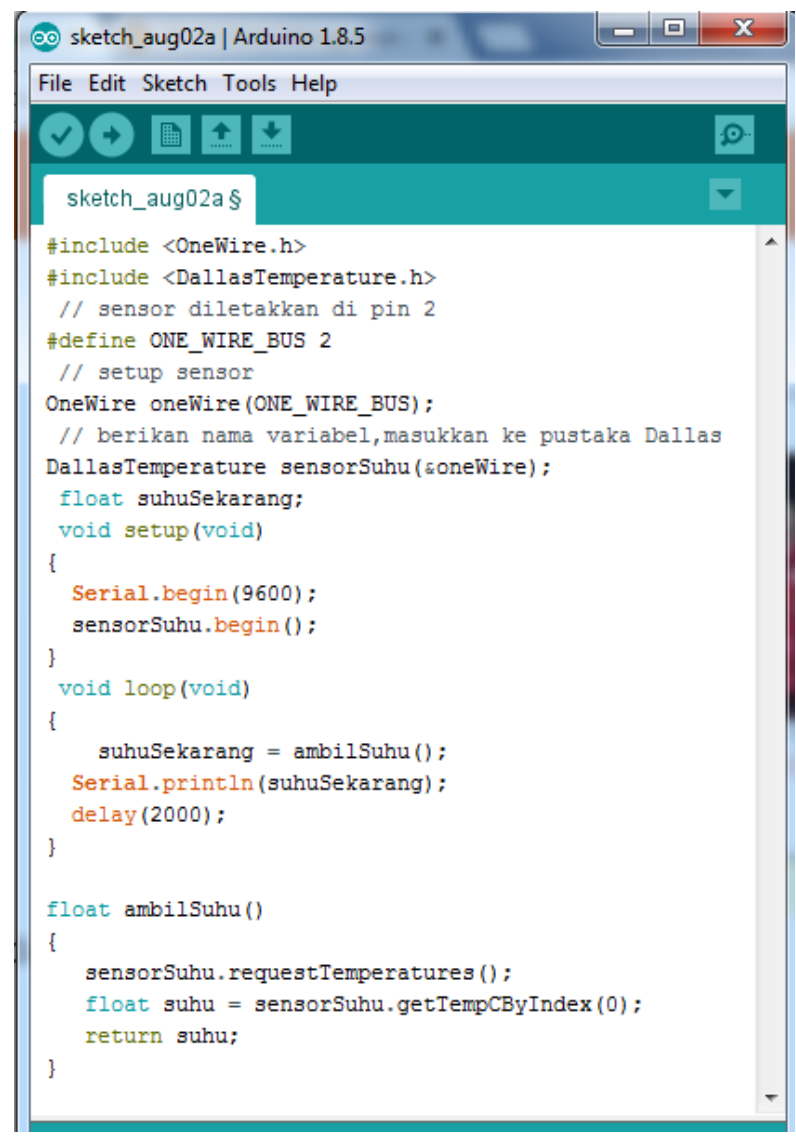


Gambar 4. Screen Shoot Pemrograman Arduino IDE Sensor DS18B20

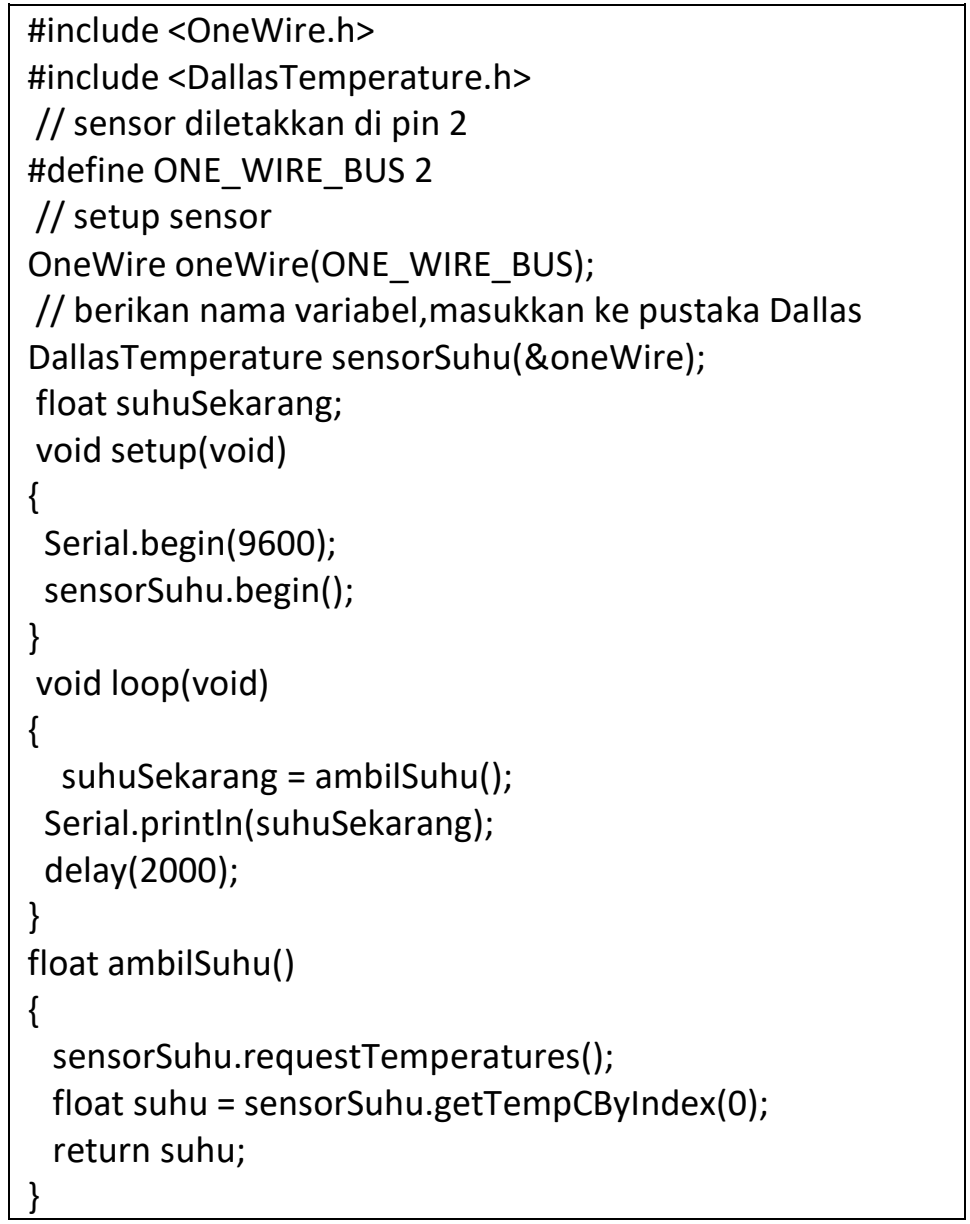

Gambar 5. Screen Shoot Pemrograman Arduino IDE Sensor DS18B20 


\section{TUGAS}

1. Tampilkan Nilai Sensor DS18B20 pada tampilan LCD $16 \times 2$, dan bandingkan hasilnya dengan sensor LM35

2. Hitung Akurasi ketepatan Sensor DS18B20 dengan alat standar. Cari nilai deviasi, ketepatan, akurasi, dan standar deviasinya terhadap alat standar. 


\section{BAB IX \\ Komunikasi Arduino dengan Android memanfaatka Bluetooth}

\section{A. TUJUAN}

Mengintegrasikan Antara Hardware dengan Android MIT App Inventor di Smartphone

B. TEORI

\section{Bluetooth}

Bluetooth adalah protokol komunikasi wireless yang bekerja pada frekuensi radio $2.4 \mathrm{GHz}$ untuk pertukaran data pada perangkat bergerak seperti PDA, laptop, HP, dan lain-lain. Salah satu hasil contoh modul Bluetooth yang paling banyak digunakan adalah tipe HC-05. modul Bluetooth HC-05 merupakan salah satu modul Bluetooth yang dapat ditemukan dipasaran dengan harga yang relatif murah. Modul Bluetooth HC-05 terdiri dari 6 pin konektor, yang setiap pin konektor memiliki fungsi yang berbeda - beda. Untuk gambar module bluetooth dapat dilihat pada gambar 1 berikut. 


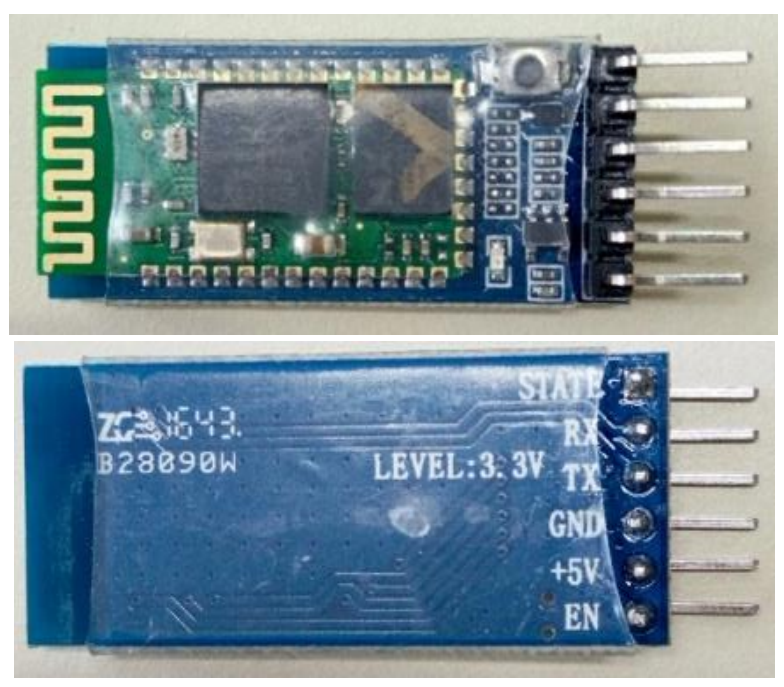

Gambar 1. Modul Bluetooth HC 05

Bluetooth dalam rangkaian digunakan sebagai pengirim data atau menerima data dari nirkabel yang $r x$ dan tx nya sama - sama bertegangan $3.3 \mathrm{vdc}$, sedangkan tegangan 5 volt digunakan untuk VCC nya. Module Bluetooth HC-05 merupakan module Bluetooth yang bisa menjadi slave ataupun master hal ini dibuktikan dengan bisa memberikan notifikasi untuk melakukan pairing keperangkat lain, maupun perangkat lain tersebut yang melakukan pairing ke module Bluetooth HC-05 (Pratama, 2014). 


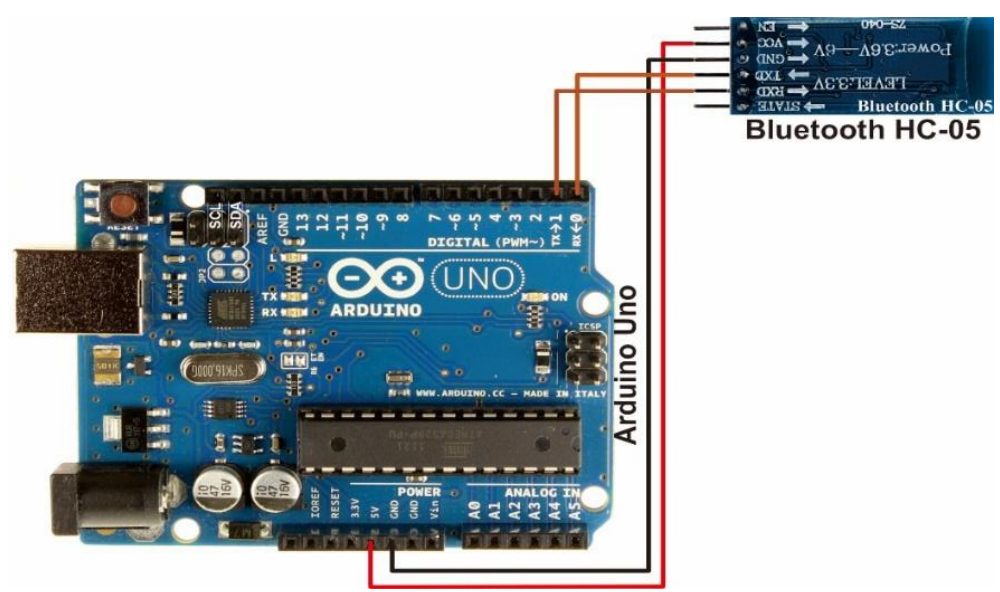

Gambar 2. Rangkaian Arduino Uno dengan Bluetooth HC-05 Tabel 1. Pengalamatan Port Mikrokontroller Arduino dengan Bluetooth hc-05

\begin{tabular}{|c|c|c|}
\hline No. & Alamat Port Arduino & Alamat Port Alat \\
\hline 1. & PD 0 & TX Bluetooth \\
\hline 2. & PD 1 & RX Bluetooth \\
\hline 3. & VCC 5 Volt & VCC \\
\hline 4. & GND & GND \\
\hline
\end{tabular}

\section{Sofware Android MIT Inventor}

Android merupakan sistem operasi untuk perangkat mobile berbasiskan linux, yang dimodifikasi sedemikian rupa, sehingga dapat dijalankan dalam perangkat seperti komputer tablet dan smartphone. Dikembangkan pertama kali oleh Android.Inc yang kemudian namanya digunakan sebagai nama proyek sistem operasi android.

Untuk aplikasi android yang berjalan dalam smartphone, dibuat dengan menggunakan Android MIT Inventor, Pembuatan aplikasi dan coding untuk android 
membutuhkan IDE (Intergration Development Evironment). Sehingga dengan aplikasi ini maka pengguna bisa membuat Aplikasi android sesuai dengan disain yang disukai dan di butuhkan.

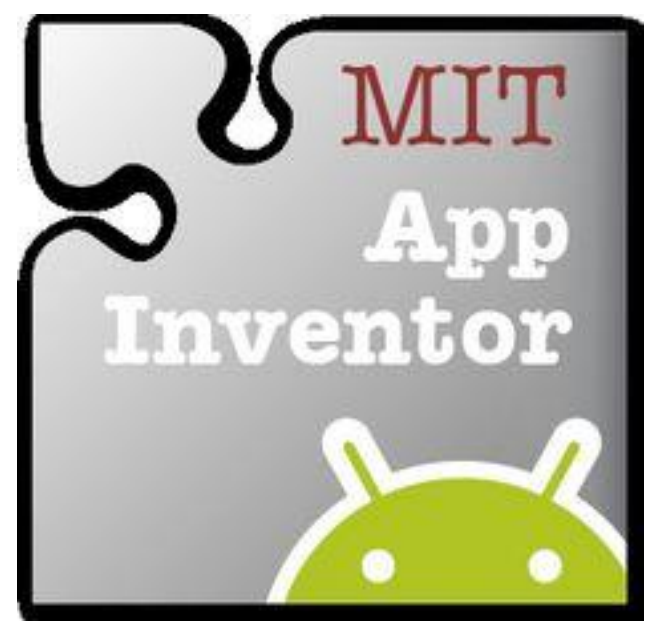

Gambar 3. Tampilan Software MIT Inventor 

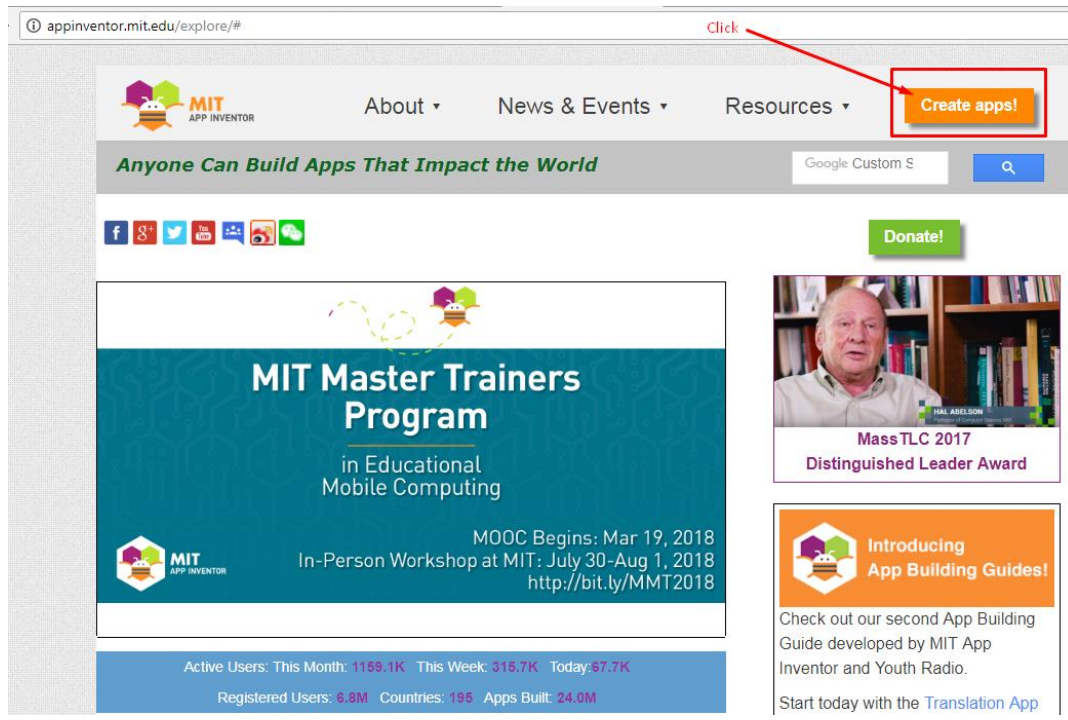

Gambar 4.Tampilan Link MIT App Inventor (http://appinventor.mit.edu/explore/\#)

Untuk MIT App Inventor dapat diakses di Link : http://appinventor.mit.edu/explore/\# untuk akun masuknya menggunakan akun Gmail. Jadi pengguna harus memiliki email Gmail agar bias mengakses ke MIT App Inventor.

Berikut ini Langkah untuk membuat Aplikasi Android dengan MIT App Inventor dan mengintegrasikan Arduino menggunakan komunikasi Bluetooth.

1. Masuk Akun MIT App Inventor dengan akun Gmail anda.

2. Buat Project baru dengan Klik Project, dan pilih Start new project seperti Gambar 1, dan beri nama Project baru 
anda. Usahakan dalam memberi nama tidak ada sepasi, jika memungkinkan memberi nama dengan spasi maka gunakan underscors ( $\left.{ }_{-}\right)$.

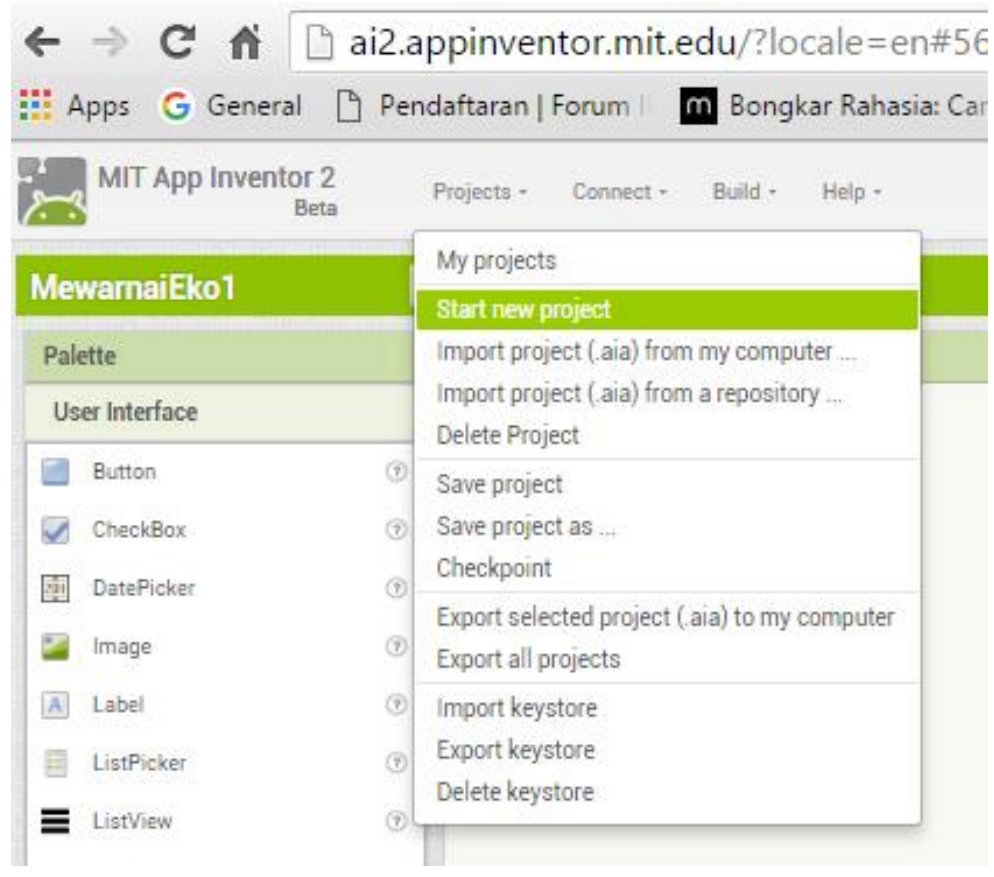

Gambar 5 Tampilan Awal Project Baru MIT App Inventor 


\section{Create naw App Inventor project}

\section{Project name:}

\section{Menana!_Anay}

\section{Cancel}

\section{OK}

Gambar 6. Pemberian Nama Project Baru

3. Manfaatkan Pallet yang ada pada Aplikasi dengan menambahkan HorizontalArranggement pada Screen1 seperti gambar berikut ini. HorizontalArranggement disini digunakan sebagai alas untuk menata posisi menu Pallet lainnya seperti button, text, dan sebagainya agar posisi menu Pallet bisa di tempatkan di tengah, samping kiri, samping kanan, bawah, maupun di posisi atas. 


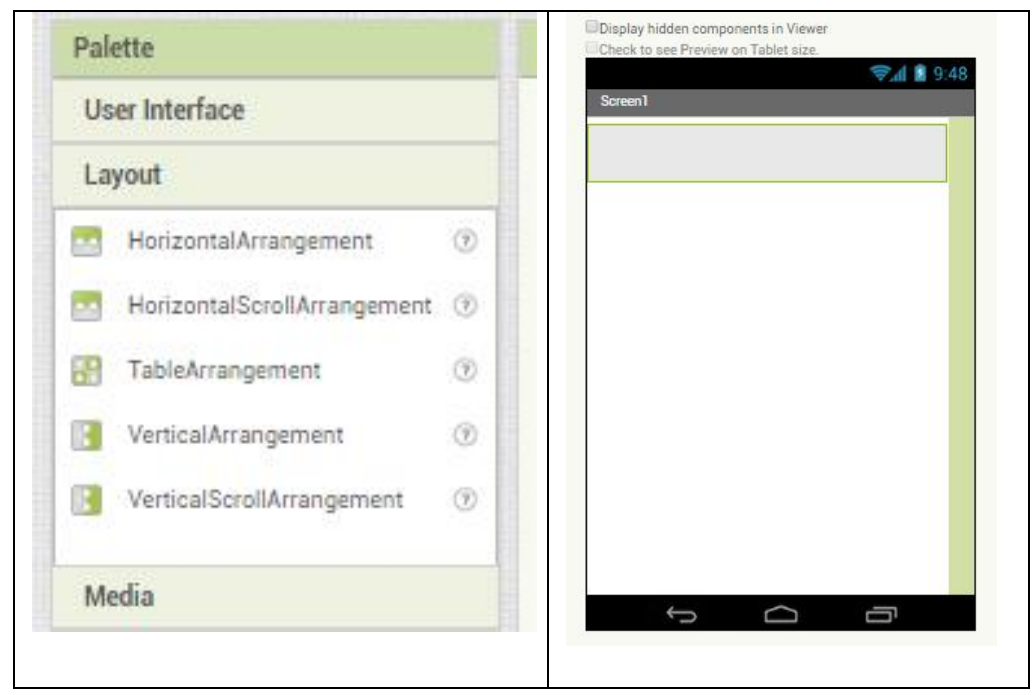

Gambar 7. Tampilan menu HorizontalArragement 


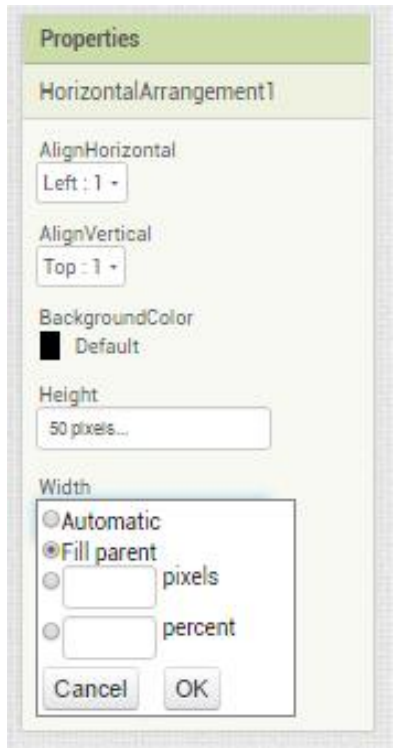

Gambar 8. Menu Pallet HorizontalArrangement

Pada menu ini anda bisa menempatkan tombol Button di posisi tengah, samping kanan, maupun samping kiri dengan memilih possi AllignHorizontal maupun AllignVertical. Untuk ukuran Aplikasi agar bisa full kiri kanan sesuaidengan ukuran layer, anda bisa pilih menu Fil parent. Menu pixels digunakan untuk menentukan seberapa panjang ukuran aplikasi yang anda perlukan. Setelah semua di isi maka silahkan tekan tombol oke. 


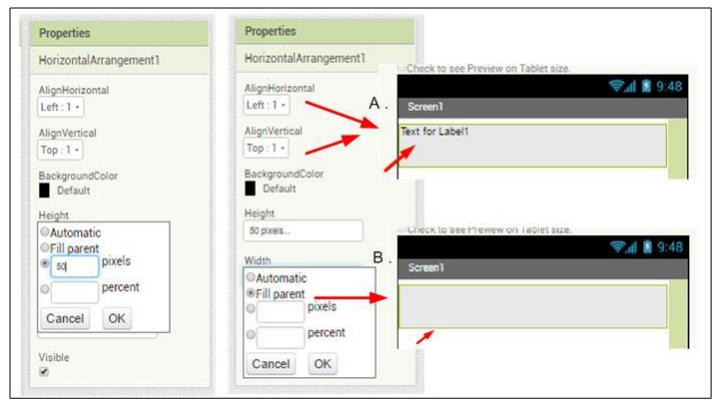

Gambar 9. Contoh setting pada HorizontalArrangement

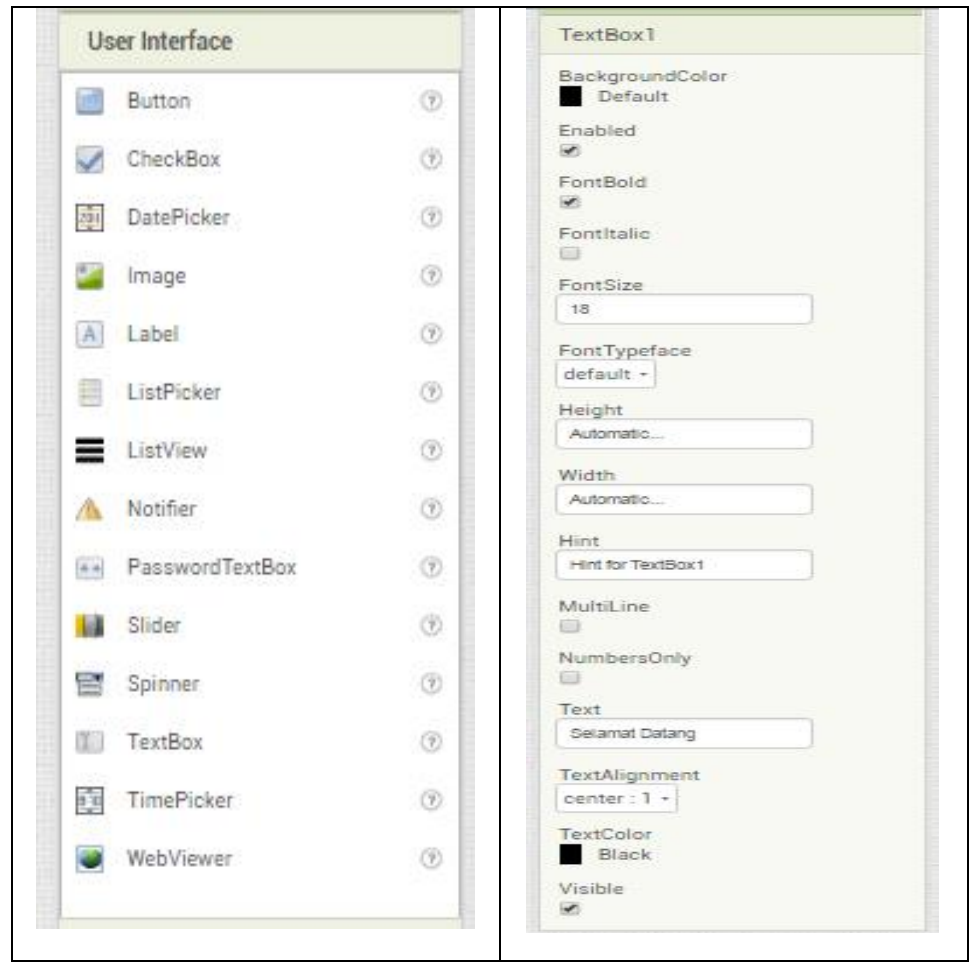




\section{Gambar 10. Komposisi User interface}

Dimenu User Interface terdapat banyak menu diantaranya Button, Label, Listpicker, image dan lainnya. Untuk membuat aplikasi Android dengan Hardware memanfaatkan Bluetooth maka gunakan tombol Button, listpiicker, bluetoothclient, clock. Untuk menambahkan image seperti tanda panah anda bisa input image dengan mengganti image di menu brose pada button atau listpicke yang sudah anda pilih. Untuk tampilan dasar komunikasi Bluetooth dengan hardware disajikan dengan contoh berikut ini. Setelah itu cobalah anda membuat menu tampilan sebagaimana gambar berikut. 


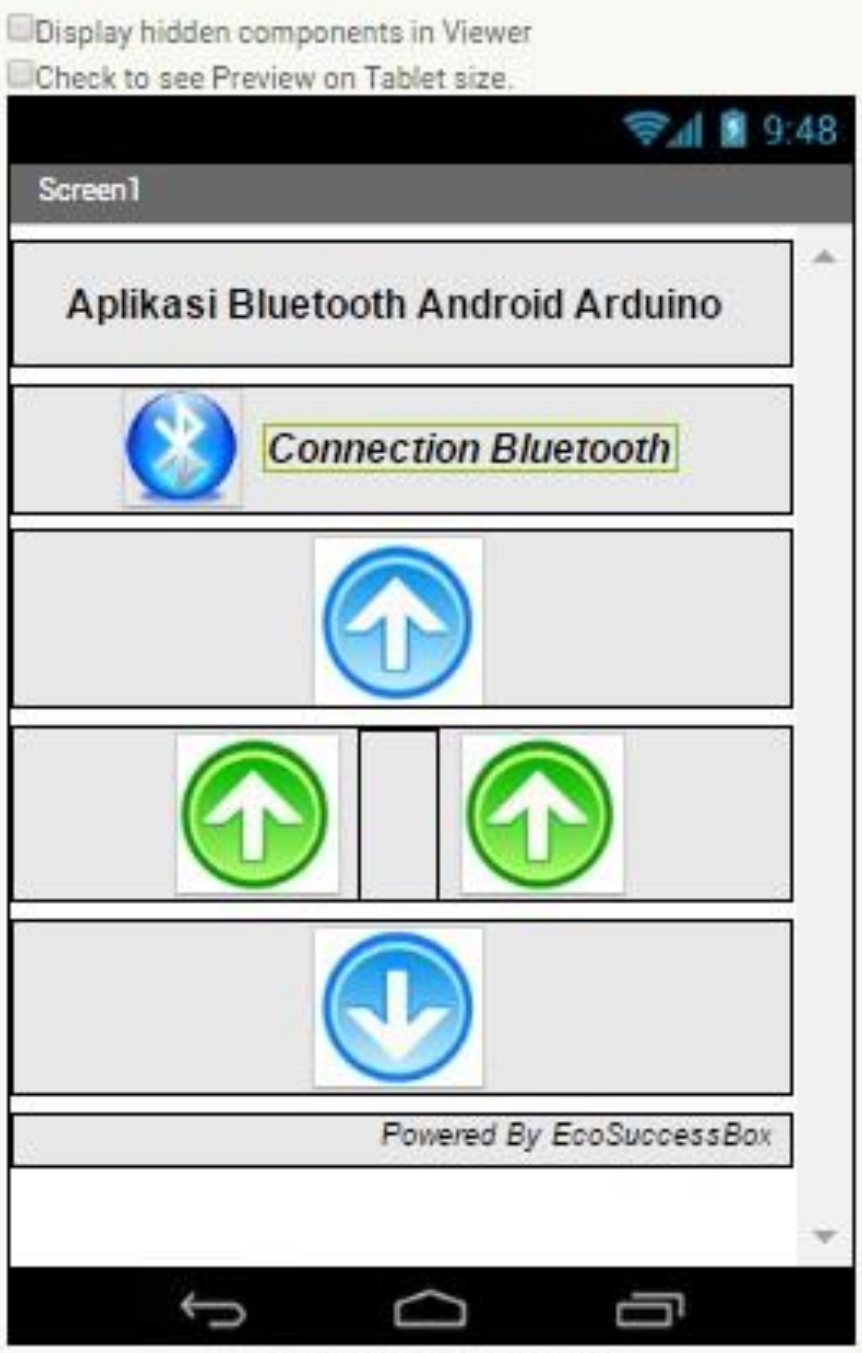

Non-visible components

BluetoothClient1 Clock1 
Gambar 11. Tampilan Aplikasi Android

Untuk memudahkan dalam pembuatan aplikasi diatas maka perhatikan table Pembuatan menu aplisi di bawah ini.

Tabel 2. Menu Pembuatan Aplikasi

\begin{tabular}{|c|c|c|c|}
\hline Gambar & Nama Menu & Gambar \& & Keterangan \\
\hline A Label & Label1 & $\begin{array}{c}\begin{array}{c}\text { Connection } \\
\text { Bluetooth }\end{array} \\
\text { Connection Bluetooth }\end{array}$ & $\begin{array}{l}\text { Untuk } \\
\text { Informasi } \\
\text { Koneksi dg } \\
\text { Bluetooth }\end{array}$ \\
\hline 国 ListPicker & Listpicker1 & & $\begin{array}{l}\text { Untuk } \\
\text { tombol } \\
\text { koneksi } \\
\text { bluetooth }\end{array}$ \\
\hline Button & Button2 & & $\begin{array}{c}\text { Tombol } \\
\text { on/off }\end{array}$ \\
\hline Button & Button5 & & $\begin{array}{l}\text { Tombol } \\
\text { on/off }\end{array}$ \\
\hline Connectivity & BluetoothClient & & Koneksi \\
\hline \begin{tabular}{|l|} 
Activitystarter \\
B \\
Bluetoothclient \\
\end{tabular} & & Bluetoothclient1 & bluetooth \\
\hline
\end{tabular}




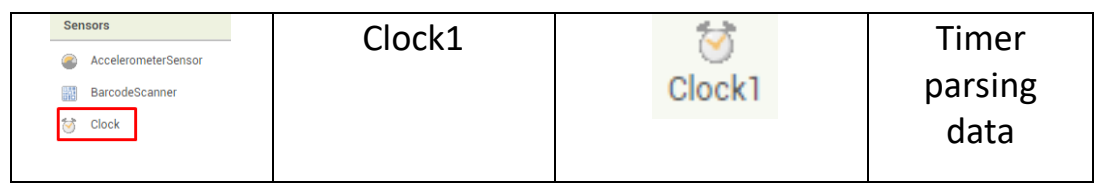

Jika semua komponen sudah terpenuhi, maka masuk ke menu pemrograman, adapun menu pemrograman dapat dilakukan dengan menekan menu blok dipojok kanan atas sebagaimana gambar berikut ini.

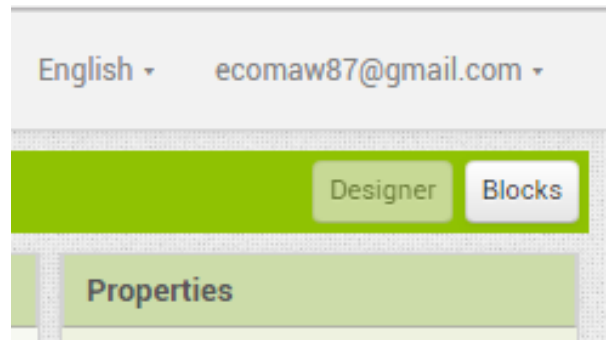

Gambar 12. Menu Blocks untuk masuk ke menu pemrograman 


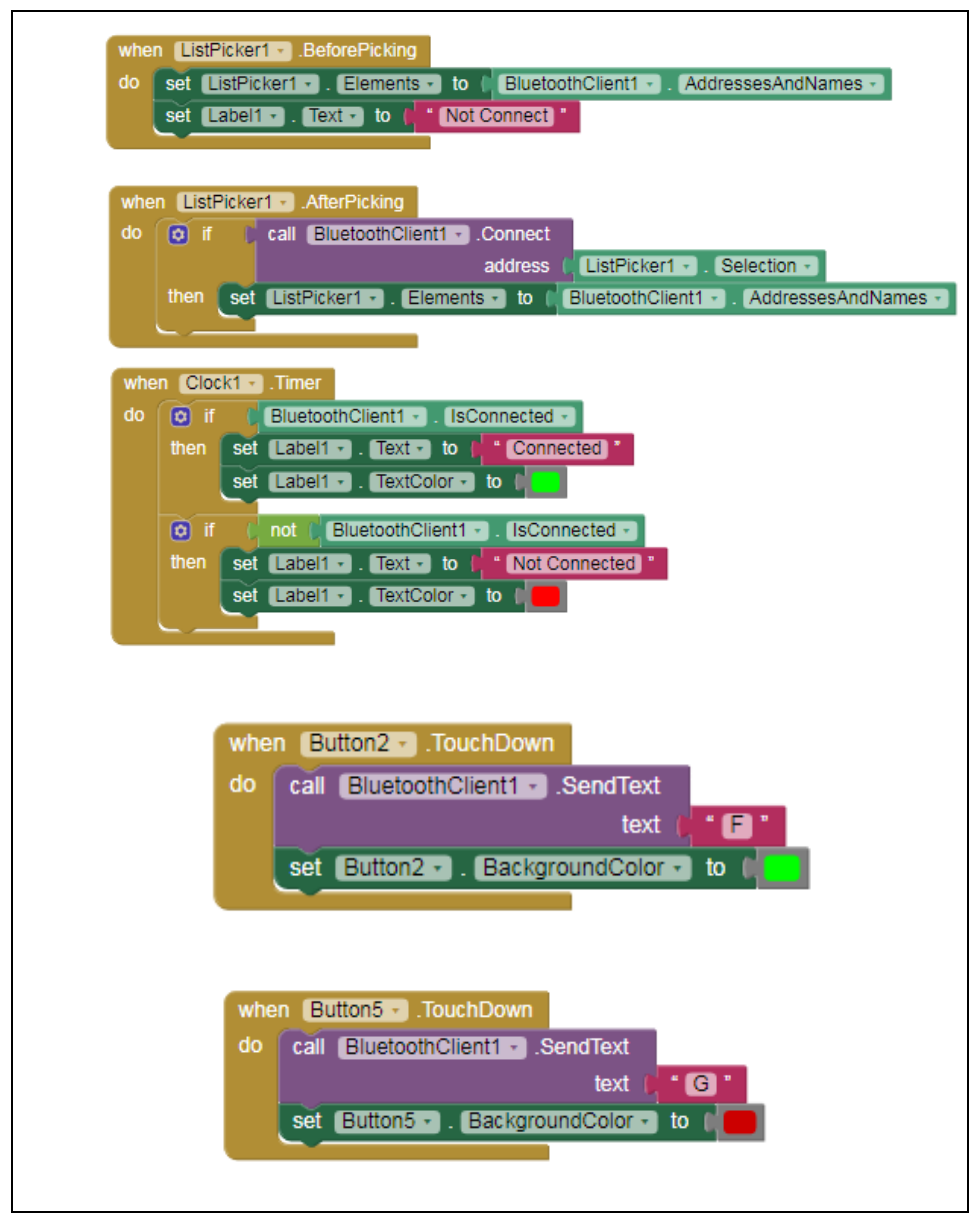

Gambar 13. Pemrograman MIT App Inventor untuk Bluetooth 
Projects - Connect - Build - Help *
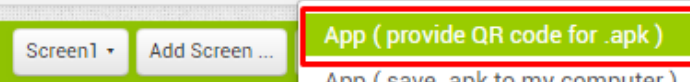

App ( save apk to my computer )

App for Google Play (provide QR code for .apk)

App for Google Play ( save .apk to my computer)

$\checkmark$ Check to see Preview on Tablet size.

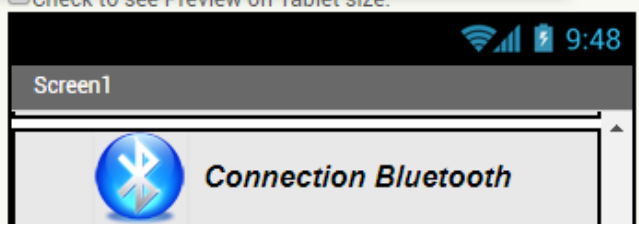

Gambar 14. Pemindahan Aplikasi Android dari desktop/PC ke Smartphone android.

Untuk memindah Aplikasi Android dari desktop/PC ke Smartphone android dilakukan dengan cara klik Build dan memilih App (Provide QR code for .apk) agar muncur barcode QR Code seperti gambar berikut.

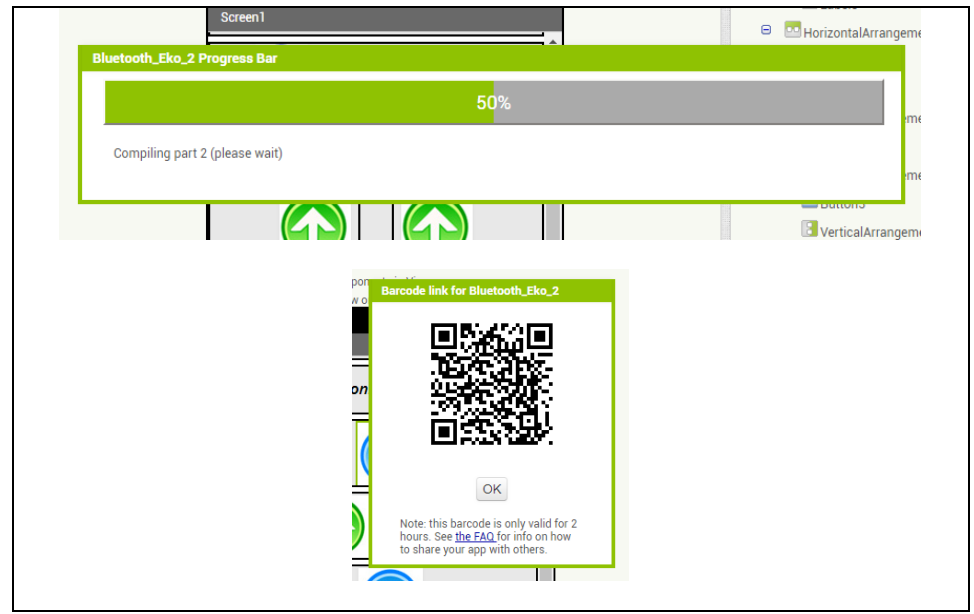


Gambar 15. Barcode QR Code untuk memindah Aplikasi android dari PC ke Smartphone.

Untuk pembacaan Barcode QR Code dapat anda lakukan dengan dengan menginstall MIT Al2 Companion yang ada di google Playstore.

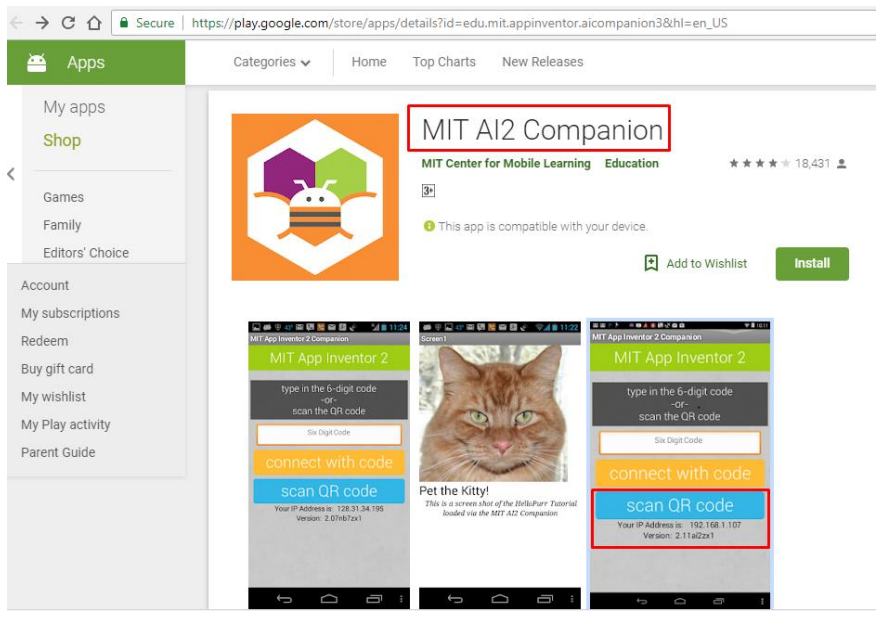

Gambar 16. MIT AI2 Companion 


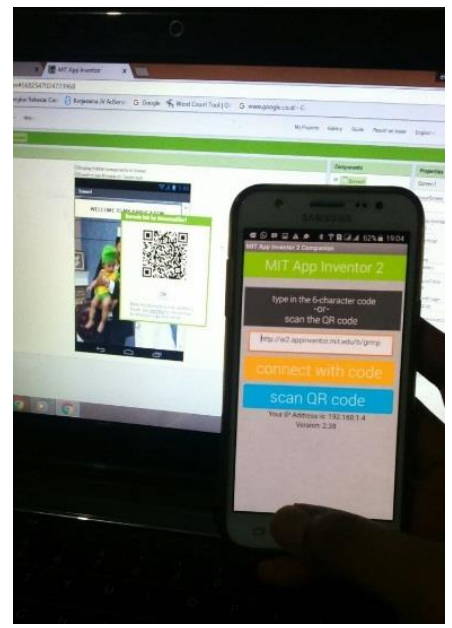

Gambar 17. Cara Pembacaan QR Code dengan MIT AI2 Companion

Untuk berikutnya melakukan Pemrograman di IDE Arduino. Pemrogramannya dibuat seperti gambar berikut ini. 


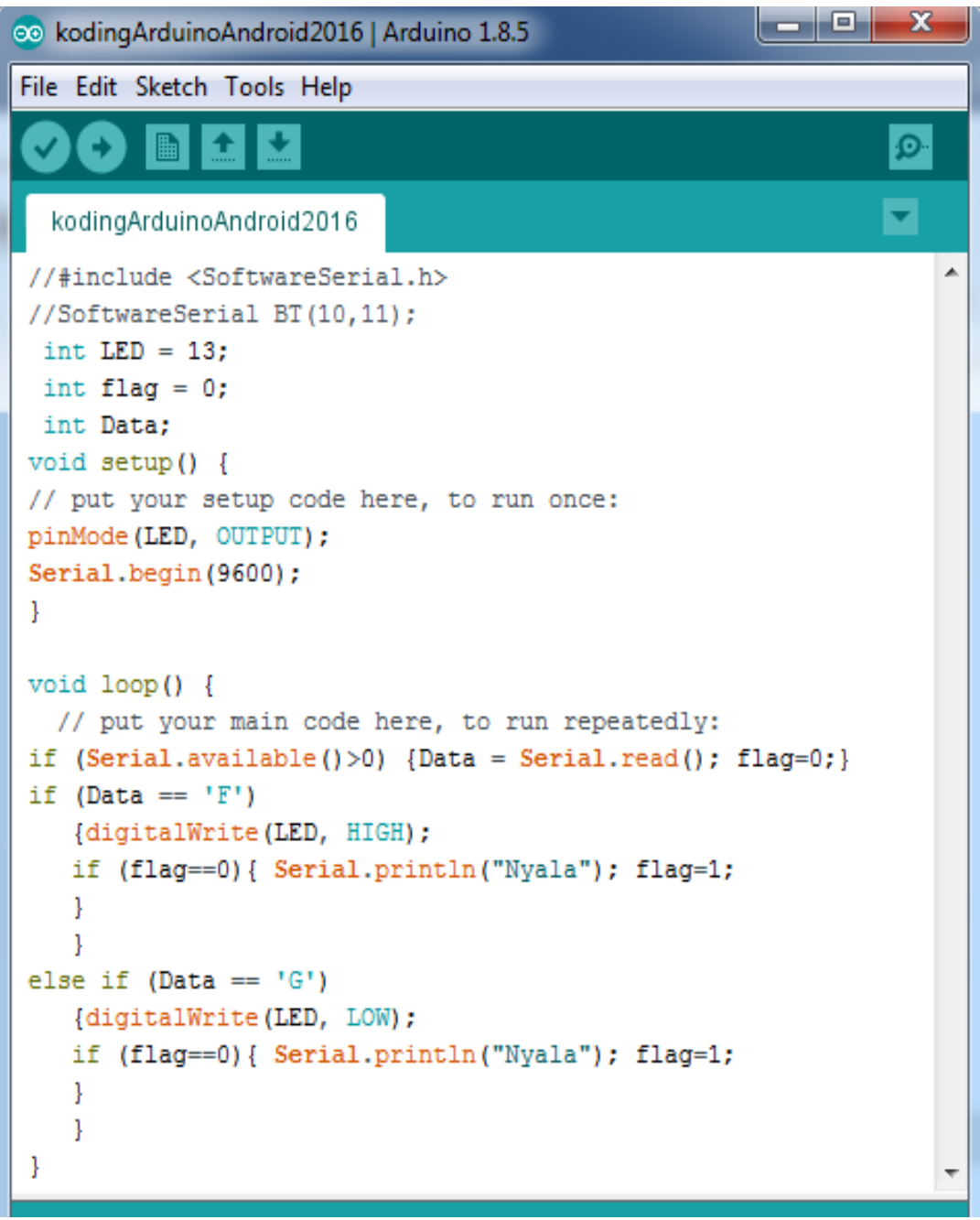

Gambar 18. Screenshoot Pemrograman IDE Arduino untuk Bluetooth 
//\#include <SoftwareSerial.h>

//SoftwareSerial BT(10,11);

int LED = 13;

int flag $=0$;

int Data;

void setup() \{

// put your setup code here, to run once:

pinMode(LED, OUTPUT);

Serial.begin(9600);

\}

void loop() \{

// put your main code here, to run repeatedly:

if $($ Serial.available ()$>0)\{$ Data $=$ Serial. $\operatorname{read}() ;$ flag $=0 ;\}$

if (Data $==$ ' $F$ ')

\{digitalWrite(LED, HIGH);

if (flag==0)\{ Serial.println("Nyala"); flag=1;

\})

else if (Data $==$ ' $G$ ')

\{digitalWrite(LED, LOW);

if (flag==0)\{ Serial.println("Nyala"); flag=1;

\}

\}

\}

Gambar 19. Pemrograman IDE Arduino untuk Bluetooth 
Untuk mengintegrasikan Arduino dengan smartphone dilakukan dengan cara sebagai berikut ini : 
1. Aktifkan Bluethoot pada Smartphone Android.

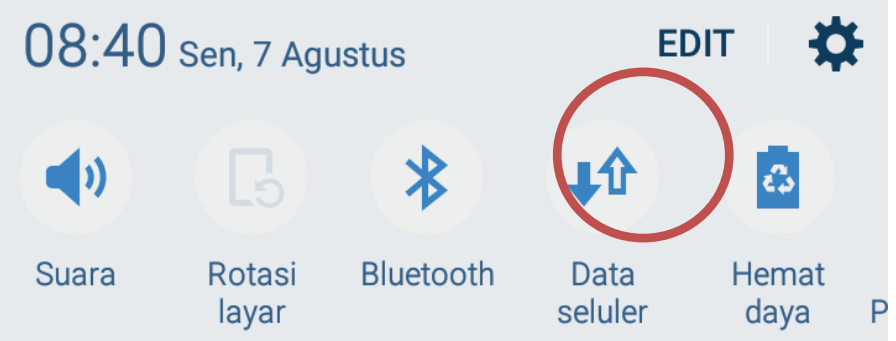

Gambar 20. Aktifkan Bluethoot pada Smartphone Android.

2. Buka aplikasi kontrol tekan icon icon gambar Bluethoot pada aplikasi Smartphone Android. 
Display hidden oomponents in Viewer

Check to see Preview on Tablet size.

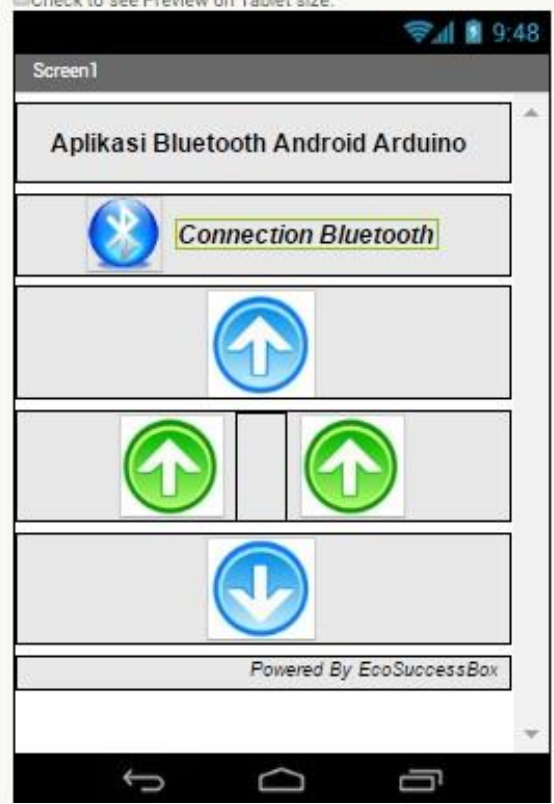

Gambar 21. Aplikasi di Smartphone Android.

3. pilih Modul Bluethoot HC-05pada daftar pencarian di smartphone anda. 


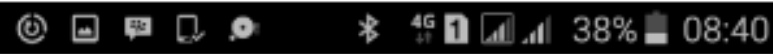

\section{Sugik R. H.}

DC:CE:BC:10:15:39 smartfren v3s

\author{
AC:C1:EE:08:8D:57 Redmi
}

7E:AE:96:65:72:87 POLYTRON W1400

\section{8:D3:32:10:9C:0F HC-05}

\section{8:E2:44:82:A4:56 DESKTOP-} DHLEC7J

Gambar 22 Pencarian koneksi bluethoot.

4. Pilih komunikasi HC 05 sebagaimana gambar 22. Jika Koneksi tersambung maka aplikasi siap digunakan untuk menggerakkan hardware atau mematikan lampu di hardware. 


\section{BAB X \\ FILTER PADA INSTRUMENTASI BIOMEDIK}

\section{A. Instrumentasi Low Pass Filter}

Instrumentasi Low Pass Filter merupakan suatu instrumetasi yang berfungsi untuk memfilter suatu sinyal frekuensi rendah. Grafik hasil uji Instrumentasi low pass filter dapat dilihat seperti gambar 4.2 dibawah ini. Grafik Instrumentasi Low Pass Filter orde 1 berbeda dengan grafik Instrumentasi Low Pass Filter orde 10, makin tinggi orde berdampak pada makin curamnya grafik dalam mendekati frekuensi cut off dan makin tinggi kepresisiannya. Salah satu contohnya Instrumentsi Low Pass Filter frekuensi Cut Off $450 \mathrm{~Hz}$, ini maksudnya suatu instrumentasi filter sinyal yang meloloskan sinyal frekuensi dibawah $450 \mathrm{~Hz}$ sedangkan sinyal diatas frekuensi $450 \mathrm{~Hz}$ di reduksi maupun di hilangkan (Gambar 4.1). Ini sangat berbeda dengan High Pass Filter dengan frekuensi cut off $20 \mathrm{~Hz}$ yang memiliki makna bahwa suatu instrumentasi filter sinyal yang meloloskan sinyal frekuensi di atas $20 \mathrm{~Hz}$ sedangkan sinyal di bawah frekuensi $20 \mathrm{~Hz}$ di reduksi maupun di hilangkan.

\section{$150 \mathrm{~Hz} \quad 300 \mathrm{~Hz} \quad 450 \mathrm{~Hz} 600 \mathrm{~Hz}$}

Gambar 4.1. Ilustrasi Low pass Filter. Sinyal Frekuensi dibawah $450 \mathrm{~Hz}$ di loloskan, sedangkan diatas $450 \mathrm{~Hz}$ dihilangkan maupun di reduksi. 


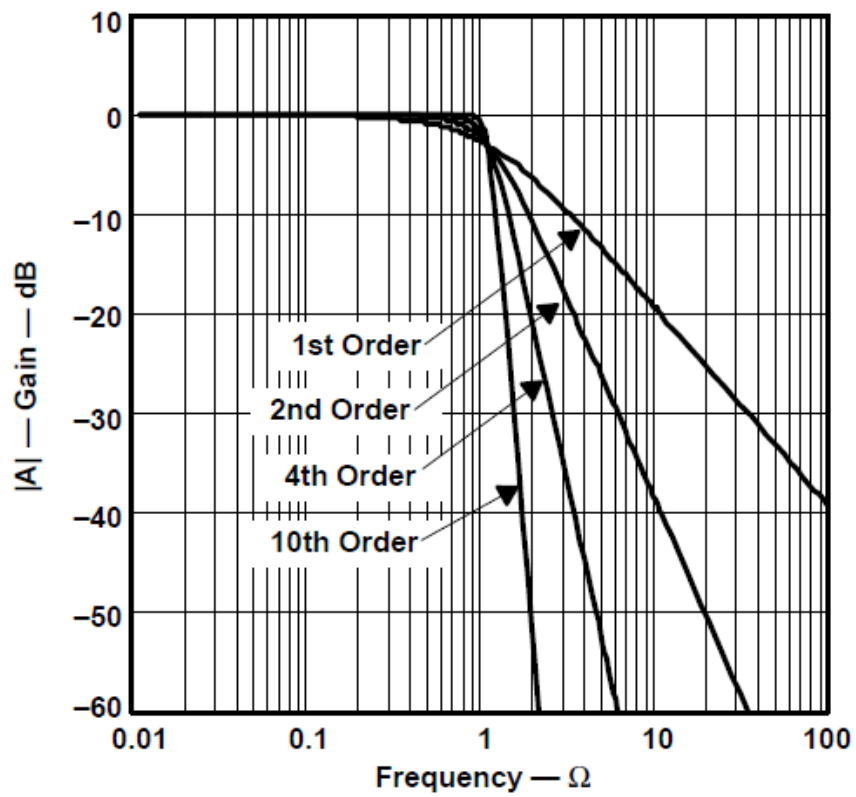

Gambar 4.2. Pola sinyal Butterworth Low-Pass Filter (Kugelstadt, 2008)

Rangkain Low Pass Filter orde 4 untuk frekuensi cutoff (fc) 500 $\mathrm{Hz}$ merupakan suatu rangkaian yang dibentuk dari 2 buah rangkaian Low Pass Filter orde 2 Sallen-Key Topology sebagaimana Gambar 4.3 dan Gambar 4.4 (Skematik).

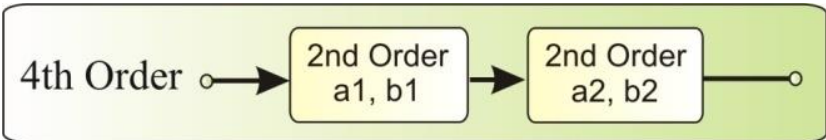

Gambar 4.3. Susunan tahapan Low Pass Filter orde 4 


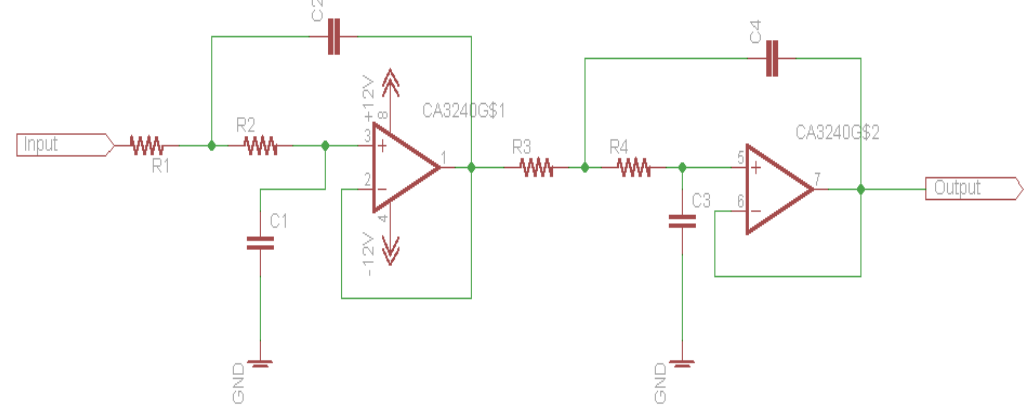

Gambar 4.4. Rangkain Low Pass Filter orde 4 frekuensi cutoff $500 \mathrm{~Hz}$

Sehingga diperlukan 2 buah rangkaian Low Pass Filter orde 2 sebanyak 2 buah untuk membuatnya. Selain itu diperlukan Nilai koefisien $a_{1}=1.8478 ; b_{1}=1.0000 ; a_{2}=0.7654$ dan $b_{2}=$ 1.0000, nilai-nilai tersebut merupakan koefisien Butterworth untuk orde 4 (lihat Tabel 4.1).

Tabel 4.1. Koefisien Butterworth Rangkain Low Pass Filter orde 4 frekuensi cut off $500 \mathrm{~Hz}$ (Kugelstadt, 2008)

\begin{tabular}{cccccc|}
\hline $\mathbf{n}$ & $\mathbf{i}$ & $\mathbf{a} \mathbf{i}$ & $\mathbf{b}_{\mathbf{i}}$ & $\begin{array}{c}\mathbf{k}_{\mathbf{i}}= \\
\mathbf{f}_{\mathbf{C i}} / \mathbf{f}_{\mathbf{C}}\end{array}$ & $\mathbf{Q}_{\mathbf{i}}$ \\
\hline 1 & 1 & 1.0000 & 0.0000 & 1.000 & - \\
2 & 1 & 1.4142 & 1.0000 & 1.000 & 0.71 \\
3 & 1 & 1.0000 & 0.0000 & 1.000 & - \\
& 2 & 1.0000 & 1.0000 & 1.272 & 1.00 \\
& 1 & 1.8478 & 1.0000 & 0.719 & 0.54 \\
& 2 & 0.7654 & 1.0000 & 1.390 & 1.31 \\
\hline
\end{tabular}

Dengan menggunakan nilai kapasitor $\mathrm{C}_{1}=46 \mathrm{nF}$, koefisien $\mathrm{a}_{1}=$ 1.8478 dan koefisien $b_{1}=1.0000$, serta nilai resistor $R_{1}, R_{2}$, dan kapasitor $\mathrm{C}_{2}$ Low Pass Filter orde 2 pertama dapat dihitung 
dengan Persamaan (4.1) dan (4.2). Sehingga didapat nilai resistor $R_{1}=R_{2}=6260.333379 \Omega$ dan kapasitor $C_{2}=$ $5.506148546211 \times 10^{-8}$ F. Low Pass Filter banyak digunakan dalam pembuatan Instrumentasi Medis, diantaranya Instrumentasi Medis Phonocardiography, Instrumentasi Medis Electrocardiography, Instrumentasi Medis Electromyograph.

Perlu diketahui bahwa dalam menghitung nilai R1, R2, R3, dan R4 maka nilai koefisien Butterworth $\mathrm{a}_{1}$ dan $\mathrm{b}_{1}$ adalah untuk rangkaian Low Pass Filter orde 2 yg pertama, sedangkan $\mathrm{a}_{2}$ dan $\mathrm{b}_{2}$ adalah untuk rangkaian Low Pass Filter orde 2 yang ke dua. Koefisien $a_{2}$ dan $b_{2}$ digunakan untuk membantu perhitungan pada rangkaian kedua, dengan mengganti nilai R1 menjadi R3 dan R2 menjadi R4. Sedangkan nilai $C_{1}$ dan $C_{3}$ semuanya sama sesuai persamaan (4.2). Rangkaian Low Pass Filter banyak digunakan dalam pembuatan instrumentasi Electrocardiography, Instrumentasi medis Elektromyograph, dan Instrumentasi Medis Carotid Pulse.

$$
\begin{gathered}
R_{1,2}=\frac{a_{1} C_{2} \mp \sqrt{a_{1}^{2} C_{2}^{2}-4 b_{1} C_{1} C_{2}}}{4 \pi f_{c} C_{1} C_{2}} \\
C_{2} \geq C_{1} \frac{4 b_{1}}{a_{1}^{2}}
\end{gathered}
$$

Dengan :

$a_{1}, b_{2}, a_{2}, b_{2}$, = koefisien Butterworth

$\mathrm{C}_{1}, \mathrm{C}_{2}=$ Kapasitor $(\mathrm{F})$

$\mathrm{R} 1, \mathrm{R} 2, \mathrm{R} 3, \mathrm{R} 4=$ Resistor (Ohm)

fc $\quad=$ Frekuensi Cut Off $(\mathrm{Hz})$ 
Pada Rangkain Low Pass Filter orde 4, perlu diketahui pula bahwa Low Pass Filter orde 2 yang kedua dihitung menggunakan Persamaan (4.1) dan (4.2) dengan mengganti nilai $R_{1}$ menjadi $R_{3}$; Nilai $R_{2}$ menjadi $R_{4}$; Kapasitor $C_{1}$ menjadi $\mathrm{C}_{3}$; Kapasitor $\mathrm{C}_{2}$ menjadi $\mathrm{C}_{4}$; koefisien $\mathrm{a}_{1}$ menjadi $\mathrm{a}_{2}$; koefisien $b_{1}$ menjadi $b_{2}$ sehingga didapatkan nilai $C_{3}=46 n F ; R_{3}=R_{4}=$ $2593.169806 \Omega$ dan $C_{4}=3.20908287893516 \times 10^{-7} \mathrm{~F}$.

\section{B. INSTRUMENTASI HIGH PASS FILTER}

Instrumentasi High Pass Filter merupakan suatu instrumetasi yang berfungsi untuk memfilter suatu sinyal frekuensi tinggi. Grafik hasil uji Instrumentasi High pass filter dapat dilihat seperti gambar 4.5 dibawah ini. 


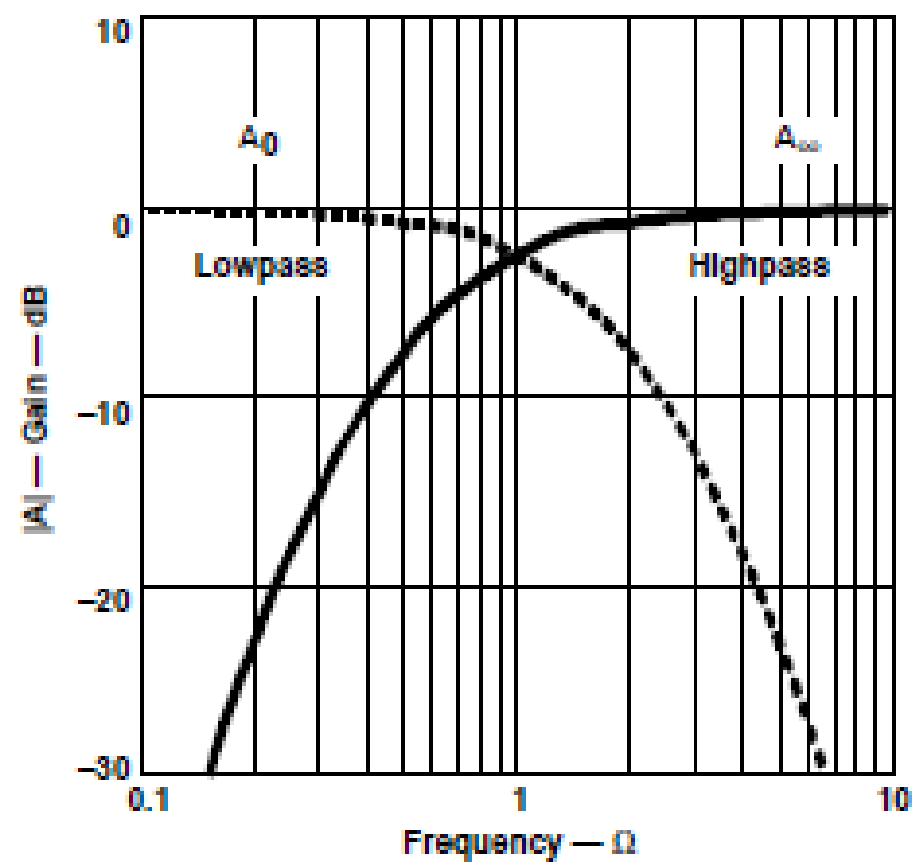

Gambar 4.5. Pola sinyal Butterworth High-Pass Filter dan Low Pass Filter

Grafik Instrumentasi High Pass Filter orde 1 berbeda dengan grafik Grafik Instrumentasi High Pass Filter orde 10, makin tinggi orde berdampak pada makin curamnya grafik dalam mendekati frekuensi cut off dan makin tinggi kepresisiannya. Salah satu contohnya Instrumentsi High Pass Filter frekuensi Cut Off $20 \mathrm{~Hz}$, ini maksudnya suatu instrumentasi filter sinyal yang meloloskan sinyal frekuensi diatas $20 \mathrm{~Hz}$ sedangkan sinyal dibawah frekuensi $20 \mathrm{~Hz}$ di reduksi maupun di hilangkan Gambar 4.6. Ini sangat berbeda dengan Low Pass Filter dengan frekuensi cut off $450 \mathrm{~Hz}$ yang 
memiliki makna bahwa suatu instrumentasi filter sinyal yang meloloskan sinyal frekuensi di bawah $450 \mathrm{~Hz}$ sedangkan sinyal di diatas frekuensi $450 \mathrm{~Hz}$ di reduksi maupun di hilangkan (gambar 4.1).

$$
10 \mathrm{~Hz} \quad 20 \mathrm{~Hz}>30 \mathrm{~Hz}>40 \mathrm{~Hz}
$$

Gambar 4.6. Ilustrasi High Pass Filter. Sinyal Frekuensi diatas $20 \mathrm{~Hz}$ di loloskan, sedangkan dibawah $20 \mathrm{~Hz}$ dihilangkan maupun di reduksi.

Rangkain High Pass Filter orde 4 untuk frekuensi cutoff (fc) $20 \mathrm{~Hz}$ merupakan suatu rangkaian yang dibentuk dari 2 buah rangkaian High Pass Filter orde 2 Sallen-Key Topology sebagaimana Gambar 4.7, Gambar 4.8, Gambar 4.9 (Skematik). Sehingga diperlukan 2 buah rangkaian High Pass Filter orde 2 sebanyak 2 buah untuk membuatnya. Selain itu diperlukan Nilai koefisien $\mathrm{a}_{1}=1.8478 ; \mathrm{b}_{1}=1.0000 ; \mathrm{a}_{2}=0.7654$ dan $b_{2}=1.0000$, nilai-nilai tersebut merupakan koefisien Butterworth untuk orde 4 (lihat Tabel 1). 


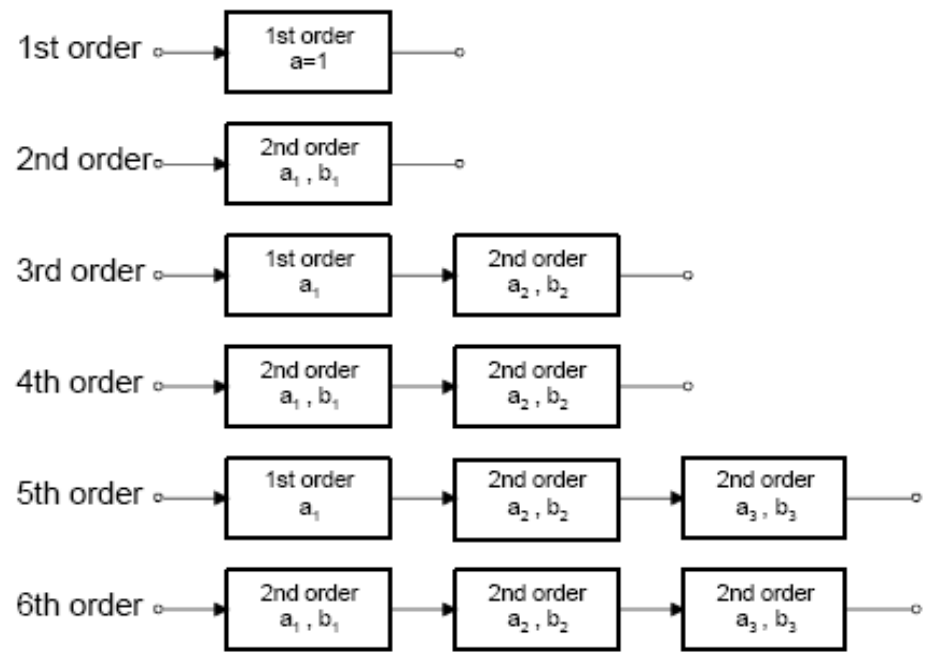

Gambar 4.7.Susunan tahapan High Pass Filter orde 1 sampai 6

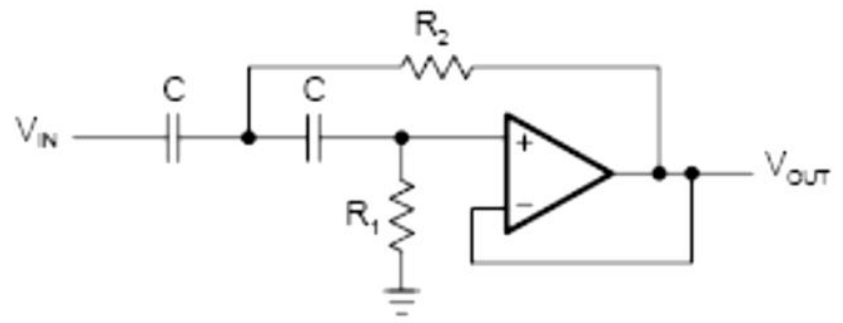

Gambar 4.8. Rangkain High Pass Filter orde 2 


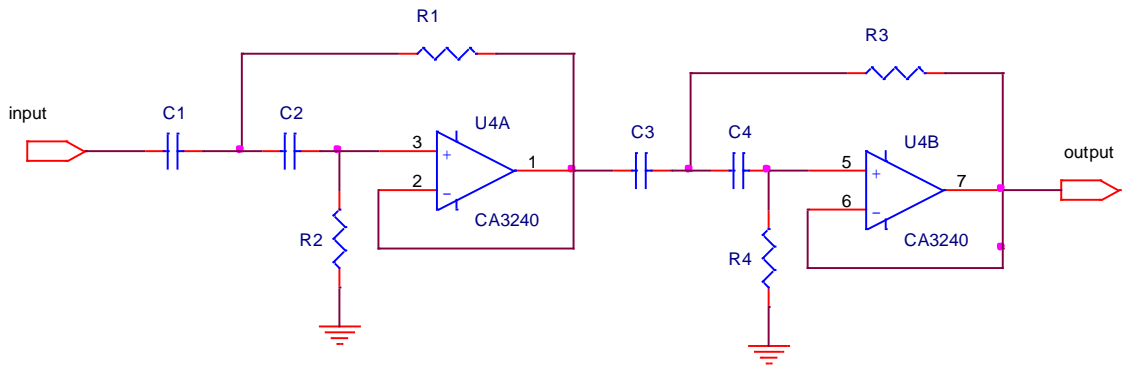

Gambar 4.9. Rangkain High Pass Filter orde 4

Dengan menggunakan nilai kapasitor $\mathrm{C}_{1}=\mathrm{C}_{2}=1 \mathrm{uF}$, koefisien $a_{1}=1.8478$ dan koefisien $b_{1}=1.0000$, serta nilai resistor $\mathrm{R}_{1}$ dan $\mathrm{R}_{2}$ High Pass Filter orde 2 pertama dapat dihitung dengan Persamaan (4.3) dan (4.4). High Pass Filter banyak digunakan dalam pembuatan Instrumentasi Medis, diantaranya Instrumentasi Medis Phonocardiography, Electromyograph dan Instrumentasi Medis lainnya.

Perlu diketahui bahwa dalam menghitung nilai R1, R2, R3, dan R4 maka nilai koefisien Butterworth $a_{1}$ dan $b_{1}$ adalah untuk rangkaian High Pass Filter orde 2 yg pertama, sedangkan $\mathrm{a}_{2}$ dan $\mathrm{b}_{2}$ adalah untuk rangkaian High Pass Filter orde 2 yang ke dua. Koefisien $a_{2}$ dan $b_{2}$ digunakan untuk membantu perhitungan pada rangkaian kedua, dengan menggganti nilai R1 menjadi R3 dan R2 menjadi R4. Sedangkan nilai $C_{1}$ dan $C_{3}$ semuanya sama menggunakan kapasitor yang sama.

$$
R_{1}=\frac{1}{\pi f_{c} C a_{1}}
$$




$$
R_{2}=\frac{a_{1}}{4 \pi f_{c} c b_{1}}
$$

Dengan :

$$
\begin{array}{ll}
a_{1}, b_{2}, a_{2}, b_{2}, & =\text { koefisien Butterworth } \\
C_{1}, C_{2} & =\text { Kapasitor (Farad) } \\
\text { R1, R2, R3, R4 } & =\text { Resistor (Ohm) } \\
f c & =\text { Frekuensi Cut Off }(\mathrm{Hz}) \\
\pi & =\text { koefisien }(3,14)
\end{array}
$$




\section{INSTRUMENTASI NOTCH FILTER}

Rangkaian Notch Filter adalah suatu rangkaian yang berfungsi untuk memfilter sinyal di frekuensi tertentu, yang diakibatkan supplay tegangan berasal dari listrik PLN 220 volt. Penggunaan Notch Filter di indonesia digunakan untuk memfilter sinyal frekuensi jala-jala PLN yang nilainya sebesar $50 \mathrm{~Hz}$. Untuk Instrumentasi medis, sinyal frekuensi $50 \mathrm{~Hz}$ jalajala PLN sangat mempengaruhi bentuk sinyal sebuah Instrumentasi medis, dan hasil penelitian yang sudah dilakukan tahun 2014 (eko, 2014) sinyal $50 \mathrm{~Hz}$ dapat merusak bentuk sinyal asli sebuah Instrumentasi Medis. Sehingga akan menyulitkan dokter dalam menganalisa bentuk sinyal tubuh, dan dapat menurunkan akurasi Analisa penyakit pasien karena noise sinyal $50 \mathrm{~Hz}$ yang merusak bentuk sinyal asli tubuh pasien. Oleh sebab itu sinyal frekuensi $50 \mathrm{~Hz}$ harus dihilangkan dengan bantuan Instrumentasi Notch Filter frekuensi Cut off $50 \mathrm{~Hz}$. 


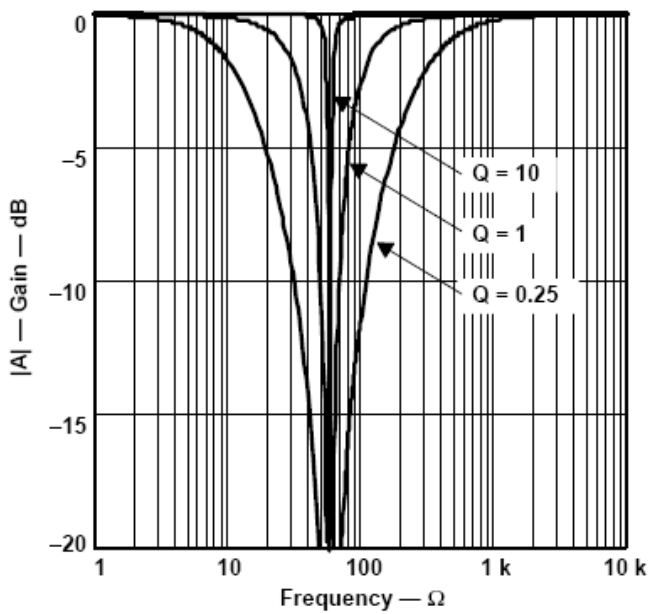

Gambar 4.10. Pola sinyal Notch Filter pada Frekuensi Cut Off tertentu. 
Rangkaian Notch Filter di tunjukkan seperti Gambar 4.11.

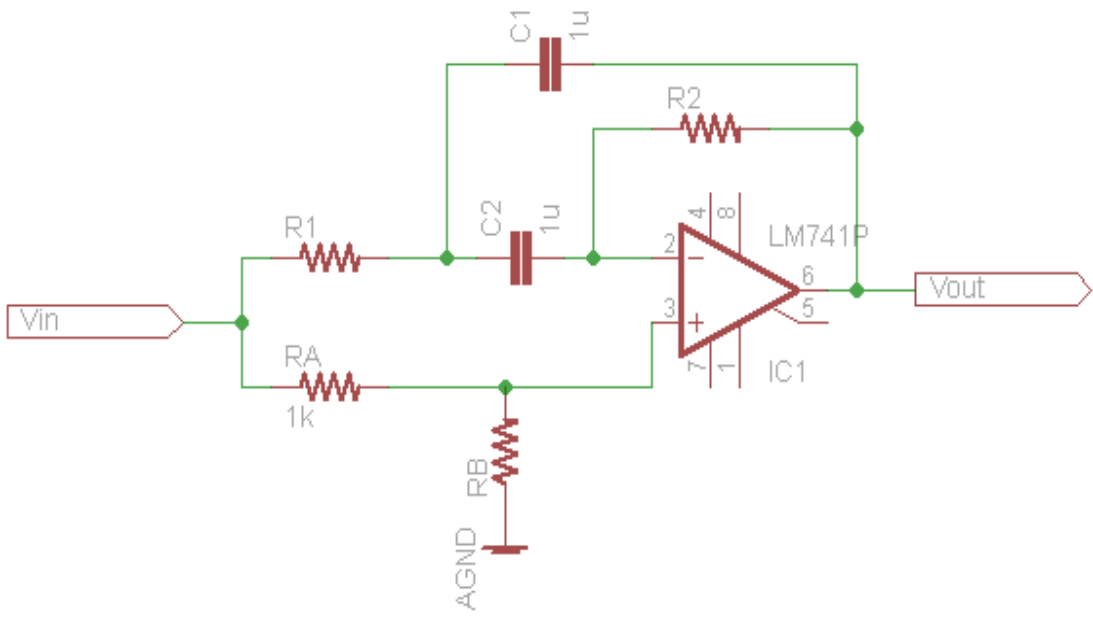

Gambar 4.11. Rangkain Notch Filter

Skematik rangkaian Notch Filter di tunjukkan pada gambar 4.11 diatas. Pada Rangkaian ini nilai kapasitor (C1) yang digunakan sebesar $1 \mu \mathrm{F}$ dan resistor $(\mathrm{RA})=1 \mathrm{k} \Omega$ dengan langkah-langkah pembuatan disain Notch Filter adalah sebagai berikut:

1. menentukan center frequency $\left(\omega_{\mathrm{r}}\right)$ dengan frequency cut off $\left(f_{o}\right)=50 \mathrm{~Hz}$ dan $\pi=314$ mengggunakan Persamaan (4.5)

2. menentukan Bandwidth (B) sebesar 50

3. nilai quality factor $\mathrm{Q}$ sebesar 6.28 dihitung dengan Persamaan (4.6). 
4. Nilai Resistor $R 2=40 \mathrm{k} \Omega$, Nilai Resistor $R 1=253.55998 \Omega$, dan nilai Resistor $\mathrm{RB}=78.8768 \mathrm{k} \Omega$ dihitung dengan Persamaan (4.7), (4.8) dan (4.9). 


$$
\begin{gathered}
\omega_{\mathrm{r}}=2 \pi \mathrm{f}_{\mathrm{o}} \\
Q=\frac{\omega_{r}}{B} \\
R 2=\frac{2}{B C} \\
R 1=\frac{R 2}{4 Q^{2}} \\
R B=2 Q^{2} R_{a}
\end{gathered}
$$

D. Simulasi Instrumentasi Low Pass Filter, High Pass Filter , dan Notch Filter di Proteus.

Simulasi Instrumentasi Filter Sinyal di Proteus akan membantu memberikan pemahaman yang lebih komprehensive akan pengertian dan pemanfaatan Instrumentasi Filter Sinyal pada Instrumentasi medis. Program yang diperlukan adalah program Proteus dengan memanfaatkan Function Generator dan Osiloskop. Berikut cara mensimulasikan instrumentasi Filter di Proteus.

\section{D.1. Low Pass Filter di Proteus}

Untuk mencoba simulasi, aktifkan proteus dan buat skematik Low Pass Filter di Proteus, pasang Osiloskop dan function generator sebagaimana gambar. 


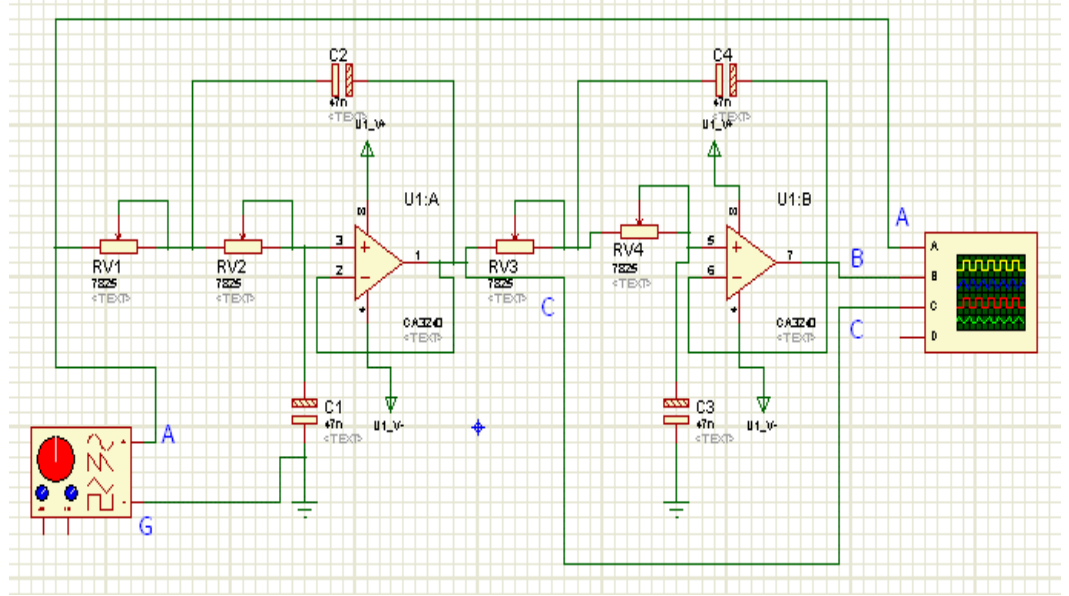

Gambar 4.12. Rangkain Low Pass Filter orde 4 frekuensi cutoff $500 \mathrm{~Hz}$ di Proteus

b) Buat skematik rangkaian Low Pass Filter di Proteus seperti gambar 4.12. Gunakan Op Amp tipe IC CA3240 serta resistor (R) dan kapasitor (C) tantalum pada rangkaian tersebut.

c) Perhatikan Gambar 4.12. Pasang Function Generator untuk titik (+) pada input rangkaian (RV1) sekaligus hubungkan dengan Osiloskop pada Sinyal A, untuk titik (-) hubungkan ke Ground (三). Hubungkan Output Instrumentasi Low Pass Filter orde 4 di titik B dengan Osiloskop pada sinyal B. Hubungkan Output Instrumentasi 
Low Pass Filter orde 2 di titik C dengan Osiloskop pada sinyal C.

d) Masukkan Nilai Resistor $R_{1}$ dan $R_{2}$ sebesar $R_{1}=R_{2}=$ $6260.333379 \Omega$ dan kapasitor $C_{2}=5.506148546211 \times 10^{-8} \mathrm{~F}$ serta $C_{1}=46 \mathrm{nF}$.

e) Run/Play simulasi pada Proteus, dan amati tampilan sinyalnya di osiloskop. Setting volt/div Chanel 1 dan Chanel 2 osiloskop pada posisi Volt/div sebesar 0.2 volt, dan Time/Div pada posisi $1 \mathrm{~ms}$, Lihat Gambar 4.13.

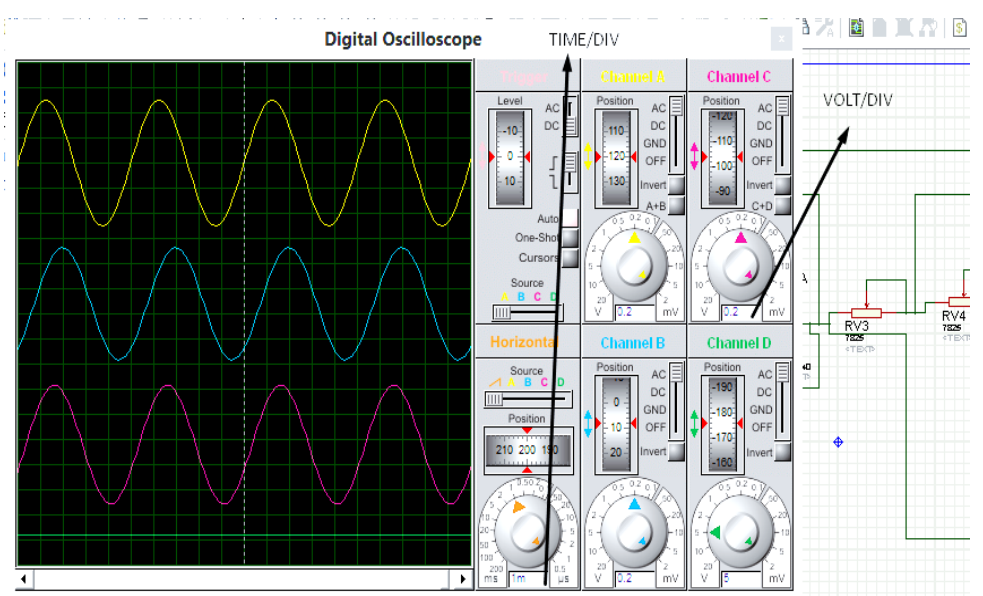

Gambar 4.13. Tampilan Osiloskop

f) Naikkan nilai frekuensi pada Function generator dari frekuensi $100 \mathrm{~Hz}, 200 \mathrm{~Hz}, 300$ hz, 400 hz, 500 hz, $600 \mathrm{~Hz}$, $700 \mathrm{~Hz}, 800 \mathrm{~Hz}, 1000 \mathrm{~Hz}$. Print Screen hasil gambarnya dan 
simpan dalam bentuk JPEG tiap-tiap frekuensi, Lihat Gambar 4.14.

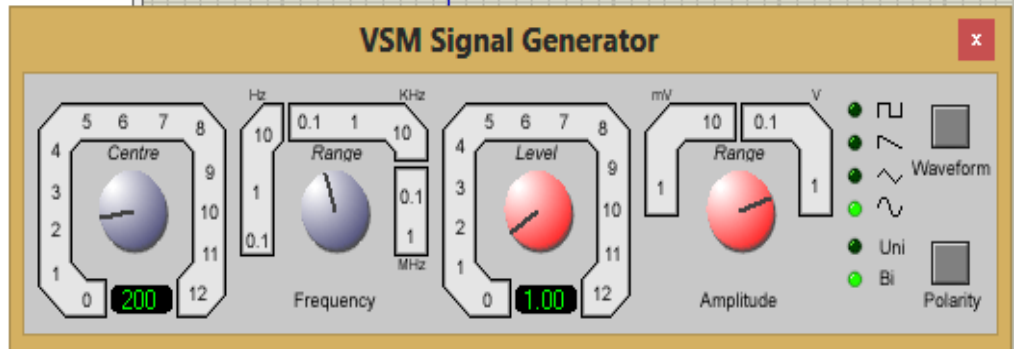

Gambar 4.14. Function Generator

g) Buat Tabel analisa tinggi Amplitud tiap frekuensi $100 \mathrm{~Hz}$, $200 \mathrm{~Hz}, 300$ hz, 400 hz, 500 hz, 600 Hz, 700 Hz, 800 Hz, $1000 \mathrm{~Hz}$ dengan cara menghitung kotak DIV nya. Seperti contoh gambar dibawah 4.15, jumlah DIV nya 5. Cari nilai tegangannya dengan cara mengalikan (Volt/Div) yang terbaca pada Osiloskop dengan jumlah kotaknya (DIV). Contohnya Volt $=0,2$ (Volt/Div) $\times 5$ Div $=1$ volt, ini sesuai dengan setting tegangan masukkan Function Generator sebesar 1 volt (Gambar 4.14). 


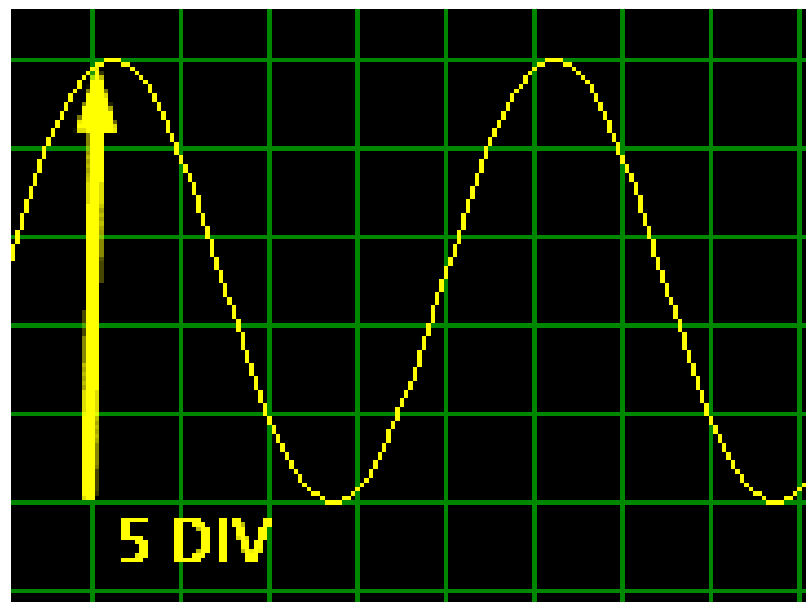

Gambar 4.15. Jumlah DIV pada Osiloskop

Untuk memudahkan menganalisa buat table Analisa sebagaimana Tabel 4.2. berikut ini. 
Tabel 4.2. Tabel pengujian Instrumentasi Low Pass Filter

\begin{tabular}{|c|c|c|c|c|c|}
\hline \multirow{2}{*}{ No } & Vin & DIV & Frekuensi & Volt & Gambar \\
\hline & Funtion & Osiloskop & & & \\
\hline 1 & 1 volt & & 100 & & \\
\hline 2 & 1 volt & & 200 & & \\
\hline 3 & 1 volt & & 300 & & \\
\hline 4 & 1 volt & & 400 & & \\
\hline 5 & 1 volt & & 500 & & \\
\hline 6 & 1 volt & & 600 & & \\
\hline 7 & 1 volt & & 700 & & \\
\hline 8 & 1 volt & & 800 & & \\
\hline 9 & 1 volt & & 900 & & \\
\hline 10 & 1 volt & & 1000 & & \\
\hline
\end{tabular}

h) Analisa pengaruh frekuensi terhadap nilai Amplitudo (DIV) nya, perhatikan perbedaannya pada tampilan Gambar di Osiloskop ketika frekuensi di setting 200 hz, $500 ~ \mathbf{~ z z ~ d a n ~}$ $800 \mathrm{~Hz}$. Hasil Analisa harus menunjukkan bahwa pada frekuensi $\geq 500 \mathrm{~Hz}$ akan terjadi penurunan amplitude sinyal yag signifikan.

\section{Latihan Soal :}


1. Hitung $R_{1}$ dan $R_{2}$ serta $R_{3}$ dan $R_{4}$ untuk frekuensi Cut Off $100 \mathrm{~Hz}$. Jika nilai C1 yang digunakan sebesar $47 \mathrm{nF}$. (Rangkain Low Pass Filter orde 4).

2. Hitung nilai tegangan Output yang ditampilkan Osiloskop di software Proteus pada saat frekuensi sinyal $50 \mathrm{~Hz}, 100$ $\mathrm{Hz}$, dan $150 \mathrm{~Hz}$ soal Nomor 1, dengan cara mengalikan (Volt/Div) yang terbaca pada Osiloskop dengan jumlah kotaknya (DIV).

3. Buat Grafik Fungsi antara nilai frekuensi (Sumbu X) dengan nilai tegangan (sumbu Y) berdasarkan data yang sudah didapatkan pada Tabel 2. 


\section{D.2. High Pass Filter di Proteus}

Untuk mencoba simulasi, aktifkan proteus dan buat skematik High Pass Filter di Proteus, pasang Osiloskop dan function generator sebagaimana gambar.

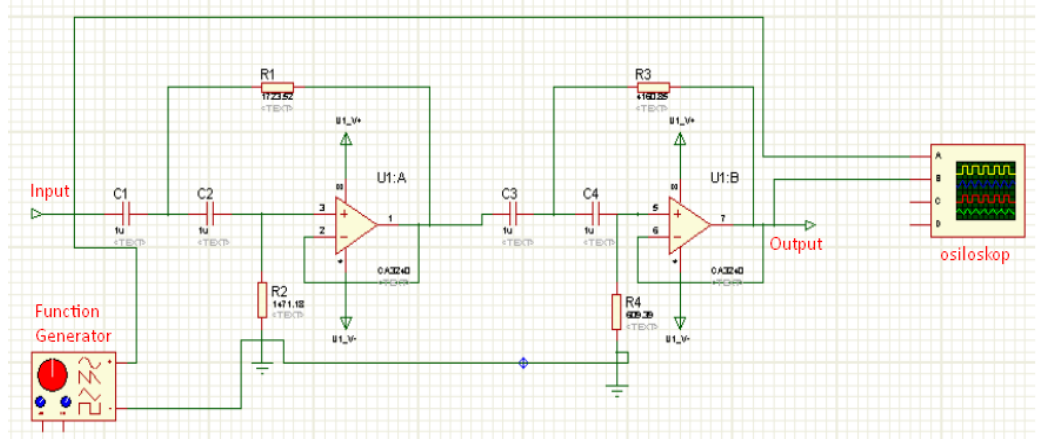

Gambar 4.16. Rangkain High Pass Filter orde 4 frekuensi cutoff $20 \mathrm{~Hz}$ di Proteus

a) Buat skematik rangkaian High Pass Filter di Proteus seperti gambar 4.16. Gunakan IC CA3240 serta resistor dan kapasitor Tantalum pada rangkaian tersebut.

b) Pasang Function Generator pada input rangkaian untuk titik (+) dan untuk titik (-) hubungkan ke Ground.

c) Untuk membantu melihat tampilan sinyal Input dan output maka Hubungkan titik A Osiloskop pada input rangkaian (C1) dan titik B Osiloskop pada Output rangkaian (OP AMP di titik 7) (Lihat Gambar 4.16). 
d) Masukkan Nilai Resistor R1, R2, R3, R4 sebesar $R_{1}=$ $1723.52 \Omega, R_{2}=1471.18 \Omega, R_{3}=4160.85 \Omega, R_{4}=609.39 \Omega$ dan kapasitor $\mathrm{C}_{2}=1 \mathrm{uF}$ serta $\mathrm{C}_{2}=1 \mathrm{uF}$.

e) Run/Play simulasi Proteus, dan amati tampilan sinyalnya di osiloskop. Setting volt/div Chanel 1 dan Chanel 2 pada osiloskop dengan disetting volt/div 0.2 volt sebagaimana icon ini Setting tegangan masukkan Function Generator sebesar 1 volt (Gambar 4.18).

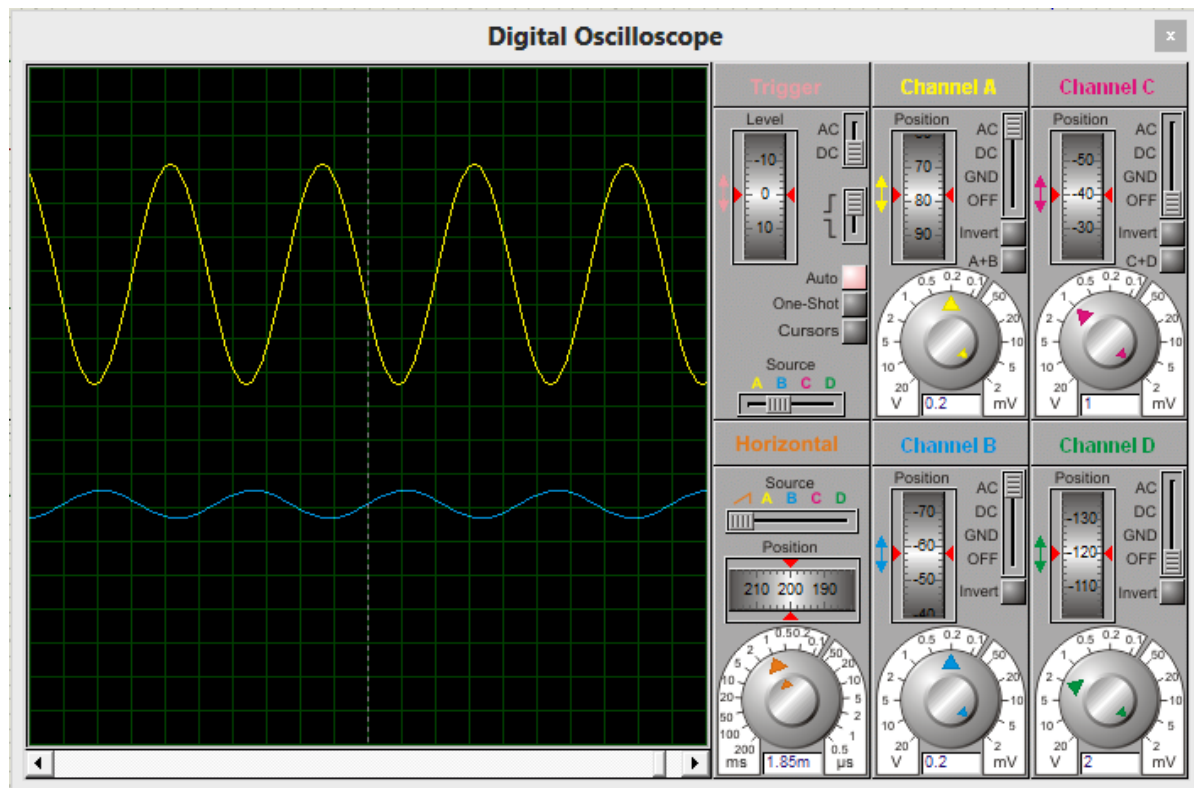

Gambar 4.17. Tampilan Osiloskop Proteus 
f) Naikkan nilai frekuensi pada Function generator (Lihat Gambar 4.18) dari frekuensi $10 \mathrm{~Hz}, 20 \mathrm{~Hz}, 30$ hz, 40 hz, 50 hz, $60 \mathrm{~Hz}, 70 \mathrm{~Hz}, 80 \mathrm{~Hz}, 90 \mathrm{~Hz}, 100 \mathrm{~Hz}$ dan 1000 Hz. Print Screen hasil gambarnya dan simpan dalam bentuk JPEG tiap-tiap frekuensi.

\section{VSM Signal Generator}

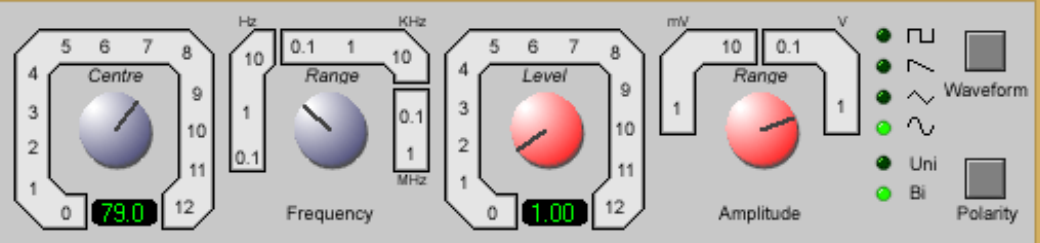

Gambar 4.18. Function Generator

g) Buat Tabel analisa tinggi Amplitud tiap frekuensi $10 \mathrm{~Hz}, 20$ $\mathrm{Hz}, 30$ hz, 40 hz, 50 hz, $60 \mathrm{~Hz}, 70$ Hz, 80 Hz, 90 Hz, 100 Hz dan $1000 \mathrm{~Hz}$ dengan cara menghitung kotak DIV nya. Seperti contoh gambar dibawah ini, jumlah DIV nya 5. Cari nilai tegangannya dengan cara mengalikan (Volt/Div) yang terbaca pada Osiloskop dengan jumlah kotaknya (DIV). Contohnya Volt $=0,2($ Volt/Div) $\times 5$ Div $=1$ volt, ini sesuai dengan setting tegangan masukkan Function Generator sebesar 1 volt (Gambar 4.18). 


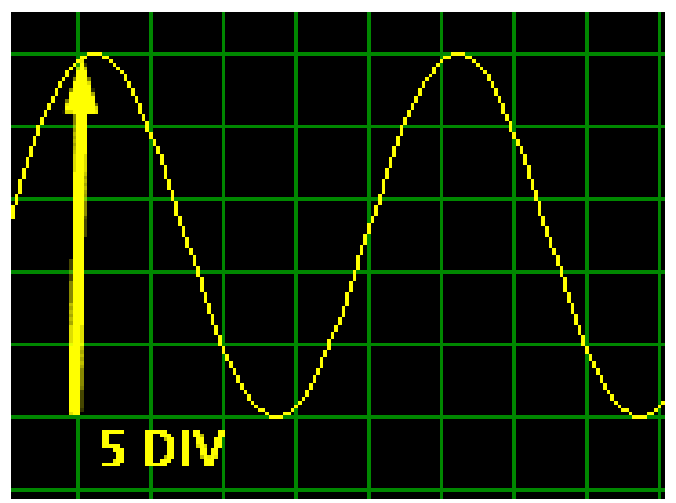

Gambar 4.19. Jumlah DIV pada Osiloskop

Tabel 4.3 Analisa data

\begin{tabular}{|c|c|c|c|c|c|}
\hline \multirow{2}{*}{ No } & Vin & DIV & \multirow{2}{*}{ Frekuensi } & \multirow{2}{*}{ Volt } & Gambar \\
\hline & Funtion & Osiloskop & & & \\
\hline 1 & 1 volt & & 10 & & \\
\hline 2 & 1 volt & & 20 & & \\
\hline 3 & 1 volt & & 30 & & \\
\hline 4 & 1 volt & & 40 & & \\
\hline 5 & 1 volt & & 50 & & \\
\hline 6 & 1 volt & & 60 & & \\
\hline 7 & 1 volt & & 70 & & \\
\hline 8 & 1 volt & & 80 & & \\
\hline 9 & 1 volt & & 90 & & \\
\hline 10 & 1 volt & & 100 & & \\
\hline 11 & 1 volt & & 1000 & & \\
\hline
\end{tabular}

h) Analisa pengaruh frekuensi terhadap nilai Amplitudo (DIV) nya, perhatikan perbedaannya pada tampilan Gambar di 
Osiloskop ketika frekuensi di setting 10 hz, $20 \mathrm{~Hz}$ dan 50 $\mathrm{Hz}$.

\section{A. Tugas}

1. Hitung R1, R2, R3, dan R4 Rangkaian High Pass Filter untuk frekuensi Cutt Off $20 \mathrm{~Hz}$. Jika nilai C1 yang digunakan sebesar 47 nF. (Rangkain High Pass Filter orde 4).

2. Hitung nilai tegangan Output yang ditampilkan Osiloskop dengan cara mengalikan (Volt/Div) yang terbaca pada Osiloskop dengan tinggi amplitude maksimal jumlah kotaknya (DIV) pada sebagaimana panduan point (g) diatas.

3. Buat Grafik Fungsi antara nilai frekuensi (Sumbu X) dengan nilai tegangan (sumbu Y) berdasarkan data yang sudah didapatkan pada Tabel 4.3. 


\section{D.3. Notch Filter di Proteus}

Untuk mencoba simulasi, aktifkan proteus dan buat skematik Notch Filter di Proteus, pasang Osiloskop dan function generator sebagaimana gambar (4.20).

Cara Kerja :

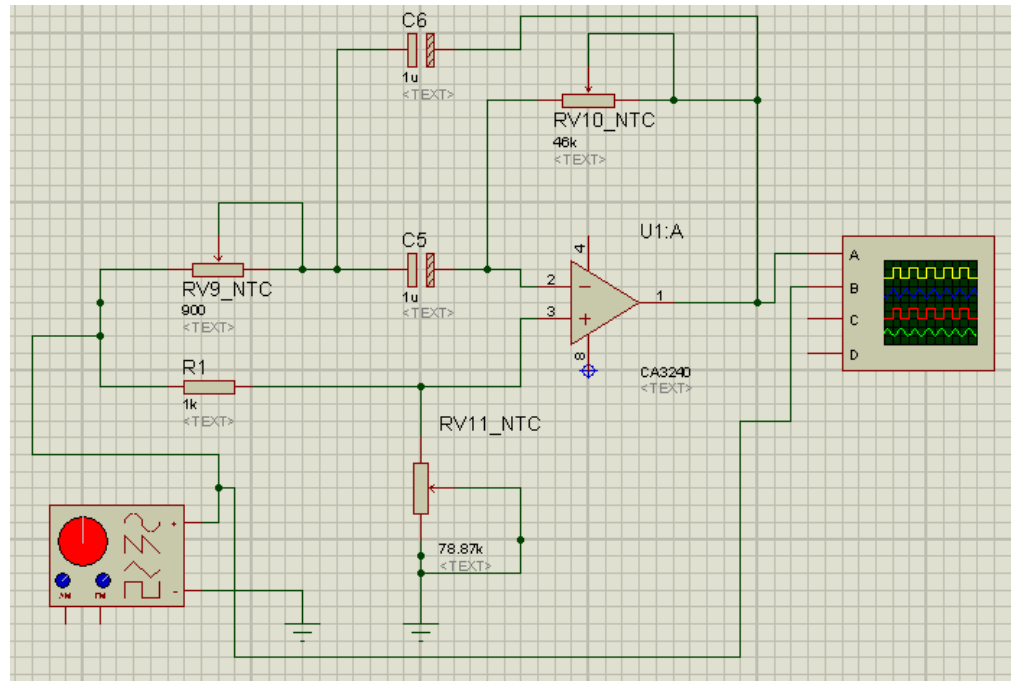

Gambar 4.20. Rangkain Notch Filter frekuensi cutoff $50 \mathrm{~Hz}$ di

Proteus

A. Buat skematik rangkaian Notch Filter di Proteus seperti gambar 4.20. Gunakan IC CA3240 serta resistor dan kapasitor Tantalum pada rangkaian tersebut.

B. Pasang Function Generator pada input rangkaian untuk titik (+) dan untuk titik (-) hubungkan ke Ground. 
C. Untuk membantu melihat tampilan sinyal Input dan output maka Hubungkan titik A Osiloskop pada input rangkaian (C1) dan titik B Osiloskop pada Output rangkaian (Lihat Gambar 420).

D. Masukkan Nilai resistor pada rangkaian untuk RV9=900 $\Omega$, $\mathrm{RV} 10=46 \mathrm{k} \Omega, \mathrm{RV} 11=78.87 \mathrm{k} \Omega, \mathrm{R} 1=1 \mathrm{k} \Omega, \mathrm{C} 5=1 \mathrm{u} \Omega, \mathrm{C} 6=$ $1 \mathrm{u} \Omega$.

E. Setting nilai frekuensi pada Function generator dari $10 \mathrm{~Hz}$, $20 \mathrm{~Hz}, 30 \mathrm{~Hz}, 40 \mathrm{~Hz}, 50 \mathrm{~Hz}, 60 \mathrm{~Hz}, 70 \mathrm{~Hz}, 80 \mathrm{~Hz}, 90 \mathrm{~Hz}, 100$ Hz. Analisa perbedaan Amplitude sinyal Input (sinyal warna Biru) dengan sinyal output (sinyal warna kuning) ketika berada di frekuensi tersebut. Amati lebih dalam ketika sinyal berada di frekuensi $50 \mathrm{~Hz}$, dan diatas maupun di bawah frekuensi $50 \mathrm{~Hz}$. Akan dihasilkan amplitude yang kecil jika berada frekuensi $50 \mathrm{~Hz}$, dan akan dihasilkan Frekuensi yang besar ketika berada di frekuensi kurang dari atau lebih dari $50 \mathrm{~Hz}$. (lihat Gambar 4.21).

F. Gambar 4.21 menunjukkan Input Function generator berapa pada frekuensi $50 \mathrm{~Hz}$ yang di tunjukkan oleh sinyal warna biru (Amplitudi 5 div), dan output sinyal function generator warna kuning (2.5 div). Hal tersebut berbeda tinggi Amplitudo sinyal Outputnya ketika Input Function 
generator berapa pada frekuensi $40 \mathrm{~Hz}$ (Gambar 4.22), Input Function generator berapa pada frekuensi $60 \mathrm{~Hz}$ (Gambar 4.23).

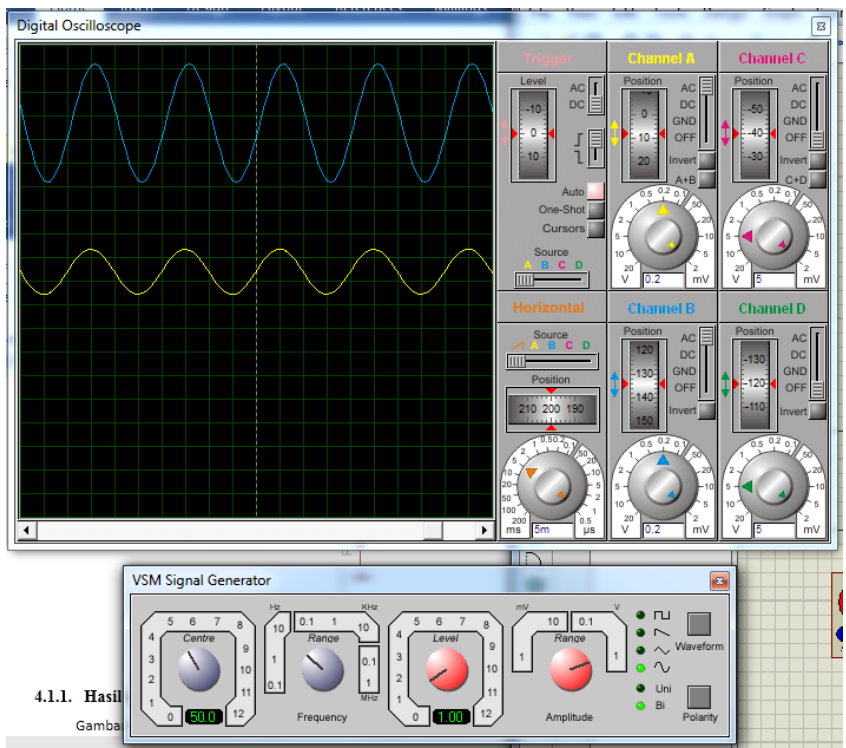

Gambar 4.21. Tampilan Osiloskop dan Function generator Notch Filter frekuensi Cut Off $50 \mathrm{~Hz}$ di Proteus 


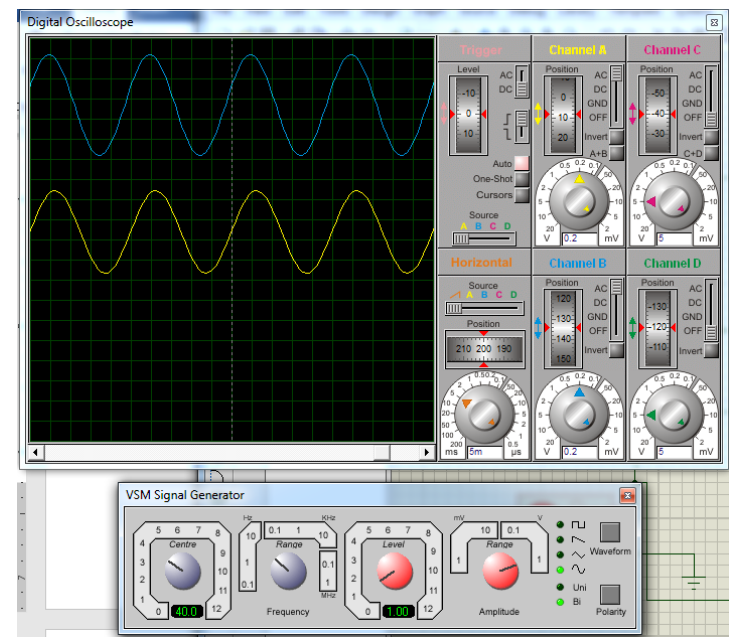

Gambar 4.22. Tampilan Osiloskop dan Function generator Notch Filter frekuensi Cut Off $40 \mathrm{~Hz}$ di Proteus 


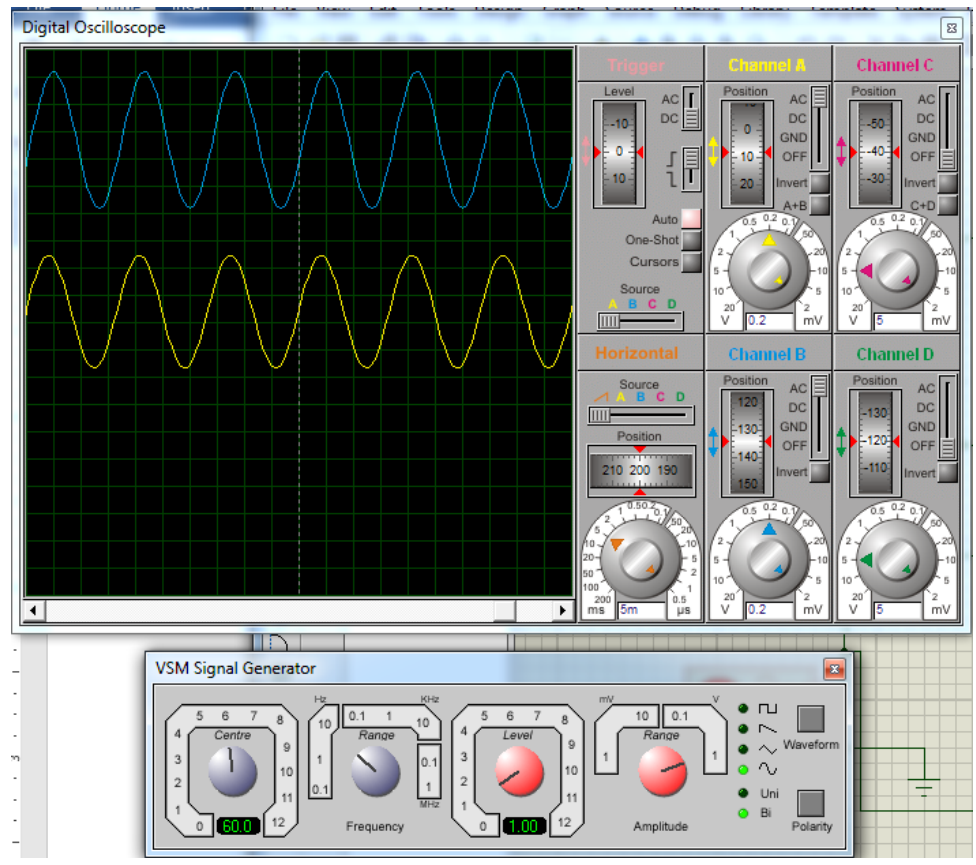

Gambar 4.23. Tampilan Osiloskop dan Function generator Notch Filter frekuensi Cut Off $50 \mathrm{~Hz}$ di Proteus

\section{A. Tugas}

1. Hitung persamaan komponen Instrumentasi Notch Filter frekuensi cut off (fc) $50 \mathrm{~Hz}$ dengan Bandwidth B sebesar 30. Pada Instrumentasi ini, nilai C1 yang digunakan sebesar $1 \mu \mathrm{F}$ dan $\mathrm{RA}=1 \mathrm{k} \Omega$.

Carilah nilai :

(a). Quality factor Q ? 
(b) Nilai R2 ?

(c). R1 ? dan,

(d). RB ?

2. Hitung persamaan komponen Instrumentasi Notch Filter frekuensi cut off (fc) $50 \mathrm{~Hz}$ dengan Bandwidth B sebesar 52. Pada Instrumentasi ini, nilai C1 yang digunakan sebesar $1 \mu \mathrm{F}$ dan $\mathrm{RA}=1 \mathrm{k} \Omega$.

Carilah nilai :
(a). Quality factor Q ?
(b) Nilai R2 ?
(c). R1 ? dan,
(d). RB ?

3. Buat Skematik Rangkaian Notch Filter soal nomor 2 di Proteus. Buat Layout yang siap dicetak di PCB, dan Sertakan tampilan 3D dengan Proteus. 


\section{Daftar Pustaka}

[1]. Dinata, Yuwono Marta. 2015. "Arduino Itu Mudah". Penderbit PT Elex Media Komputindo.

[2]. Andrianto, Heri. 2016. "Arduino Belajar Cepat dan Pemrograman". Penerbit Informatika Bandung.

[3]. Darmawan, Aan. 2016. "Arduino Belajar Cepat dan Pemrograman". Penerbit Informatika Bandung.

[4]. Wardhana, Lingga. 2006. "Belajar Sendiri Mikrokontroler AVR Seri AT Mega32 Simulasi, Hardware, Aplikasi". Penerbit Andi Offset Yogyakarta.

[5]. Kadir, Abdul. 2013. "Panduan Praktis Mempelajari Aplikasi Mikrokontroler dan Pemrogramannya Menggunakan Arduino". Penerbit Andi Yogyakarta.

[6]. Mubarak T, Sumaryo S. Abdurohman M. 2008. "Seminar Nasional Aplikasi Teknologi Informasi(SNATI 2008)". ISSN:1907-5022. Yogyakarta.

[7]. Ahmadi, Aziz. 2009. Kendali Penerangan Rumah jarak jauh menggunakan Short Message Service (SMS). Jurnal Fisika dan aplikasinya (Neutrino) Vol.1, No.2 2009.ISSN 1979-6374, EISSN 2460-5999, Department of Physics, Faculty of Sains and Technlogy, Maulana Malik Ibrahim State Islamic University of Malang.

[8]. Kilian, Christopher T.1996. " Modern Control Technology".

[9]. O. W. Pratama and H. K. S. Safitri, "Sistem Kendali Gerak Robot Menggunakan PC Berbasis Bluetooth," J. Elektron. Otomasi Ind., vol. 1, pp. 51-57, 2014 
[10]. Webster, J.G., 1978, Medical Instumentation Application and Design, Hougton Mifflin Co.

[11]. Tompkins, W.J., and J.G. Webster, 1981, Design of Microcomputer Based Medical Instrumentation, New Jersey: PHI.

[12]. Aston, R., 1991, Principles of Biomedical Instumentation and Measurement, New York: Merrill.

[13]. Tompkins, J., 1974, Biomedical Digital Signal Processing, Prentice Hall Inc. Network Design, Tata McGraw

[14]. Hill.

[15]. Barbara L. Christe, 2009, Introduction To Biomedical Instrumentation, Cambridge university

[16]. Proceding The 6th- Electrical Power, Electronics, Communications, Controls and Informatics International Seminar 2012, 30-31 Mei, Universitas Brawijaya, Malang, Indonesia

[17]. YouTube, Browsing Artikel terkait.

[18]. Thomas Kugelstadt, 2008. "Chapter 16 Active Filter Design Techniques, Literature Number SLOA088," Texas Instruments, Post Office Box 655303, Dallas, Texas 75265

[19]. E.A. Suprayitno, R.Hendra, A. Arifin, "Analisa Sinyal Electrocardiography dan Phonocardiography Secara Simultan Menggunakan Continuous Wavelet Transform," Proceedings of the The 6th - EECCIS Seminar 2012 at Brawijaya University, Malang, pp. B181 - B18-6, 2012. 
[20]. Ranagayyan, "Biomedical Signal Analysis A Case-Study Approach," IEEE Press, John Wiley \& Sons, INC, Canada, 2002 


\section{BIODATA PENULIS}

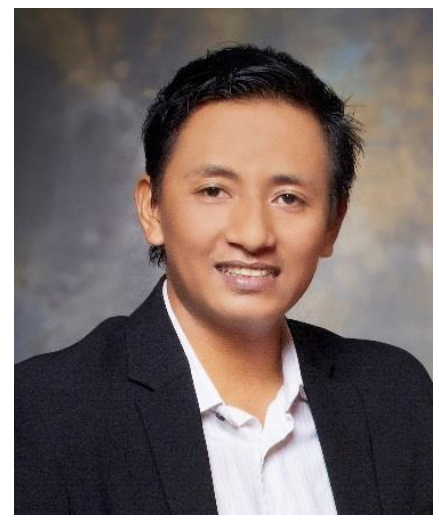

Eko Agus Suprayitno, S.Si.,MT, lahir di Pasuruan, 13 Agustus 1987, anak pertama dari 2 bersaudara dari pasangan Bapak Karijono dan Ibu Sumiani. Penulis tercatat sebagai dosen tetap di Universitas Muhammadiyah Sidoarjo mulai tahun 2013, pada Program Studi Teknik Elektro. Latar belakang Pendidikan penulis dimulai pada jenjang Strata-1 tahun 2005 di Universitas Airlangga Surabaya Jurusan Fisika. Jenjang pendidikan Master angkatan tahun 2010 diraih penulis di Institut Teknologi Sepuluh Nopember Surabaya Jurusan Teknik Elektro dengan konsentrasi Elektronika Medis dan lulus pada tahun 2012. Penulis juga aktif dalam melakukan penelitian, utamanya berkaitan dengan Elektronika Medis dan Robotika, serta puluhan hasil penelitiannya sudah dipublikasikan baik di Proceding Seminar dan Jurnal secara Nasional maupun Internasional yang berhubungan dengan Instrumentasi Medis maupun otomasi mesin. Penulis Juga sudah mengajukan HAKI atas salah satu karya ciptaannya dan Penulis Juga merupakan Reviewer Nasional Ristekdikti 2018 untuk PKM 5 Bidang serta PKM AI \& GT. Penulis dapat dihubungi di alamat email : eko.agus@umsida.ac.id 


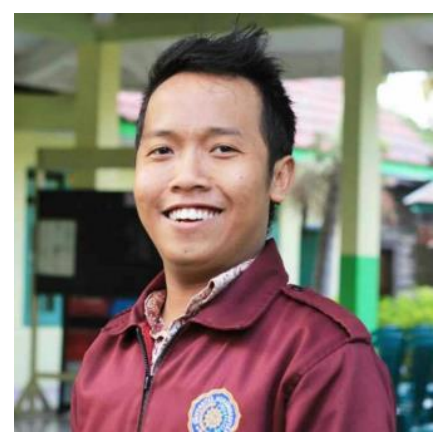

Rohman Dijaya. Skom., M.Kom, lahir di Gresik, 23 April 1990, Penulis tercatat sebagai dosen tetap di Universitas Muhammadiyah Sidoarjo mulai tahun 2016, pada Program Studi Teknik Informatika. Latar belakang Pendidikan penulis dimulai pada jenjang Strata-1 tahun 2009 di Universitas Muhammadiyah Gersik Jurusan Teknik Informatika. Jenjang pendidikan Master angkatan tahun 2014 diraih penulis di Institut Teknologi Sepuluh Nopember Surabaya Jurusan Teknik Informatika dengan konsentrasi Komputasi Cerdas dan Visual dan lulus pada tahun 2016. Penulis juga aktif dalam melakukan penelitian, utamanya berkaitan dengan Komputasi Cerdas dan Visual, sudah banyak hasil penelitiannya yang sudah dipublikasikan baik di Proceding Seminar dan Jurnal secara Nasional maupun Internasional yang berhubungan dengan Komputasi Cerdas dan Visual. Penulis Juga sudah mengajukan HAKI atas salah satu karya ciptaannya. Penulis dapat dihubungi di alamat email : rohman.dijaya@umsida.ac.id 


\section{Referensi}

[1]. D. Juliasari Noni, "Aplikasi Monitoring Suhu dan Kelembaban Ruang Server PT Hero Supermarket Tbk.".

[2]. B. S. Putra et al., "Desain Dan Implementasi Sistem Monitoring Dan Manajemen Baterai Mobil Listrik Design and Implementation of Electric Car Battery," vol. 2, no. 2, pp. 1909-1916, 2015.

[3]. B. Yuwono, Optimalisasi Panel Sel Surya dengan menggunakan sistem pelacak berbasis mikrokontroler AT89C51. 2005.

[4]. D. T. B. Sihombing and I. S. T. K. Msi, "PERENCANAAN SISTEM PENERANGAN JALAN UMUM DAN TAMAN DI AREAL KAMPUS USU DENGAN MENGGUNAKAN TEKNOLOGI TENAGA SURYA (APLIKASI DI AREAL PENDOPO DAN LAPANGAN PARKIR). Departemen Teknik Elektro Fakultas Teknik Universitas Sumatera Utara," Singuda Ensikom, vol. 3, no. 3, pp. 118-123, 2013.

[5]. D. Y. STEVANUS, PELUANG PEMANFAATAN LAMPU LED SEBAGAI LAMPU PENERANGAN YANG HEMAT ENERGI. 2011.

[6]. F. Mubarok, PENGEMBANGAN MEDIA PEMBELAJARAN BERBASIS MOBILE APPLICATION MENGGUNAKAN APP INVENTOR PADA MATA PELAJARAN MEKANIKA TEKNIK UNTUK SISWA KELAS X STUDI KEAHLIAN TGB SMK NEGERI 3 YOGYAKARTA. 2015.

[7]. H. Susanto, R. Pramana, S. T. Mt, M. Mujahidin, and S. T. Mt, "Perancangan Sistem Telemetri Wireless Untuk 
Mengukur Suhu Dan Kelembaban Berbasis Arduino Uno R3 Atmega328P Dan Xbee Pro," Jur. Tek. Elektro, Fak. Tek. Univ. Marit. Raja Ali Haji, 2013.

[8]. O. W. Pratama and H. K. S. Safitri, "Sistem Kendali Gerak Robot Menggunakan PC Berbasis Bluetooth," J. Elektron. Otomasi Ind., vol. 1, pp. 51-57, 2014.

[9]. R. H. Muhammad, R. S. Adi, and A. Kondisi, "Rancang Bangun Sistem Pengamanan Mobil Menggunakan ID Card Dengan Metode Radio Frequency Identification," vol. 1, no. 1, pp. 39-44, 2017.

[10].R. Raban, P. Surya, and B. Converter, "DESAIN DAN IMPLEMENTASI CHARGER BATERAI PORTABLE MENGGUNAKAN MODUL IC XL6009E1 SEBAGAI BOOST CONVERTER DENGAN MEMANFAATKAN TENAGA SURYA."

[11].T. A. Djoko Adi Widodo, Suryono, PEMBERDAYAAN ENERGI MATAHARI SEBAGAI ENERGI LISTRIK LAMPU PENGATUR LALU LINTAS, vol. 2, no. 2. 2010. 